\title{
THE PREDICAMENT OF ANTITRUST \\ JURISPRUDENCE: ECONOMICS AND \\ THE MONOPOLIZATION OF \\ PRICE DISCRIMINATION \\ ARGUMENT'
}

\author{
RUdOlPh J. PERITZ*
}

\begin{abstract}
Adherents to the Law and Economics Approach (LEA) claim that the incoherence of antitrust doctrine is attributable to a "policy at war with itself" and that only an unrivaled regime of efficiency can resolve this predicament. To demonstrate this rule of reason's jurisprudential impossibility as well as its ethical undesirability, Professor Peritz examines three strains of scholarship addressing price discrimination doctrine-an area already dominated by LEA argument. He finds that the LEA's success at the symbolic level only veils its substantive inadequacies. In particular, he explains why the LEA's exclusion from rational argument of the Robinson-Patman Act, antitrust's symbol of anti-effciency, fails to provide the expected rationalization of price-discrimination argument.
\end{abstract}

\section{TABLE OF CONTENTS}

I. INTRODUCTION .................................. 1207

A. The Predicament ......................... 1207

B. Commentators and Critics: Trustees of Rational Argument ............................... 1209

II. The Strain of Rationality: Politics and Price

DisCRIMINATION .............................. 1213

A. Edwards and the Politics of Discrimination .......... 1213

1. The Statute: Politics or Economics? .............. 1214

2. The FTC: Politics or Expertise? ............... 1218

3. Politics and Rationality..................... 1222

B. The 1955 AG Committee Report: Price Discrimination and the Rule of Reason ........................ 1223

1. Rule of Reason: Old Debates Discounted.......... 1226

(C) Rudolph J. Peritz 1984

* Associate Professor of Law, Rutgers Law School, Camden, New Jersey. J.D., 1975, University of Texas. This article is based in part on research done while $I$ was a Langdell Fellow at Harvard Law School. I wish to express my appreciation to the Law School as well as to the friends and colleagues who gave helpful comments on earlier drafts. Janice Haney-Peritz, Robert Hickok, and Robert A. Williams were particularly generous with their time and support. 
2. Standard Oil-Modern Developments ............ 1227

3. An Old Perspective Restored ................... 1228

III. The Strain OF IRRATIONALITY: A CONCERTEd REFUSAL To DEAL .................................. 1231

A. Rowe's Legal Discrimination as Mere Difference ...... 1234

1. The Denial of Political Discrimination ............ 1235

2. Mere Legal Price Discrimination ................ 1237

3. The Logic of Economic Discrimination ............ 1241

a. A cost price matrix ..................... 1241

b. Price discrimination: a neutral phenomenon .... 1244

(i) Static indifference.................... 1244

(ii) Dynamic indifference ................ 1244

c. Analysis without cure .................... 1245

B. Bork's "Typhoid Mary": A Call for Quarantine ....... 1246

1. Social Purposes Doctrine..................... 1247

a. Wealth maximization and political neutrality.... 1248

b. Wealth maximization and congressional intent .. 1248

2. Transfer-of-Power Theory ..................... 1250

a. From theory to doctrine ................... 1250

b. Two critiques of leverage theory ............ 1251

3. Typhoid Fever and Quarantine................ 1258

IV. The Strain of Monopolization: A Logic of

EfFiciency ................................. 1262

A. An Areedaic Vignette of Monopolization ............ 1262

B. An Isomorphic Structure: Posnerian Monopolization .... 1263

1. Monopolized Argument: Exclusion and Presumption

........................................ 1265

a. First exclusion: legal price discrimination ...... 1266

b. Second exclusion: social grounds ............. 1266

c. First presumption: legislative history and efficiency ........................... 1268

d. Second presumption: two instances of empirical determinacy.......................... 1269

2. Monopoly and Ideology: A Contradiction

Transformed ............................ 1271

a. Uncovering a political economy ............. 1271

b. Two examples of barriers to entry ............ 1273

c. An old contradiction in new clothes ............ 1277

C. Price Discrimination and Posner's Marginal

LOGIC OF EFFICIENCY .......................... 1279

1. Efficiency as Teleology ....................... 1279

2. Efficiency as Epistemology ................... 1282 
a. Productive efficiency ..................... 1283

b. Allocative efficiency ...................... 1284

c. Posner's efficiency logics.................. 1287

V. Conclusion: Logic at the Margin ................. 1292

\section{INTRODUCTION}

\section{A. The Predicament.}

This article examines the predicament of antitrust jurisprudenceits analytic incoherence and doctrinal fragmentation. Adherents to the Law and Economics Approach (LEA) to antitrust analysis characterize this predicament as the unavoidable consequence of competing value sytems, as "an antitrust paradox: a policy at war with itself." In particular, they claim that so long as both rational economic analysis and political "populist" concerns are taken into consideration, we simply cannot develop coherent antitrust doctrine. For them, an unrivaled commitment to the LEA is the necessary precondition to rationalize antitrust doctrinal development.

This article interrogates the LEA's claim by analyzing its discourse. This analysis is inspired by the work of contemporary philosophers and social theorists. ${ }^{2}$ Its purpose is to demonstrate the LEA's strategies for convincing us of its unrivaled value-its logic and its ethic. Thus, the methodological approach differs from both traditional legal scholarship and Law and Economics, although traces of both appear. The difference is significant in that this article not only looks at particular texts to unravel their arguments, but also puts a series of LEA-inspired works into chronological and sociopolitical perspective to show how LEA argument style has changed over time, even though its political vision has not. Finally, it demonstrates that the LEA, according to its own tenets, has failed to rationalize antitrust argument. The arena for this critical analy-

1. See, e.g., R. Bork, The Antitrust Paradox: A Policy at WAR With Itself 6-7 (1978).

2. See, in particular, M. Foucault, MADNESS ANd Civilization (1965) (discusses the shift in discourse on madness which accompanied epistemological changes from the Middle Ages through the Classical Age of Reason); M. Foucault, Discipline AND Punish (1976) (discusses the shift in discourse on penal institutions and on the power to punish from the eighteenth to the nineteenth centuries); M. FouCAULT, POWER/KNOWLEDGE 63-108 (1980) (two lectures describing Foucault's methodologies and his sense of the relationship between knowledge and power); J. DERRIDA, WRITING AND Difference 31-63 (1978) (critique of Madness and Civilization); J. Derrida, OF GramMATOLOGY (1970) (analysis of system of ideas which has regulated the notion of the "sign," writing, and western metaphysics); M. SERRES, HERMES (1982) (discusses parallel development of scientific, philosophical, and literary trends). 
sis is price discrimination doctrine and the Robinson-Patman Act. ${ }^{3}$ This arena is chosen for two reasons.

First, all antitrust scholars agree that traditional statutory interpretation and doctrinal development in this area are incoherent. ${ }^{4}$ Indeed, the Robinson-Patman Act has come to symbolize all that is wrong with

3. Robinson-Patman Act, 15 U.S.C. $\S 13$ (1982), amending the Clayton Act, 15 U.S.C. $\$ 12$ 27 (1982). The Act provides in pertinent part:

(a) It shall be unlawful for any person engaged in commerce, in the course of such commerce, either directly or indirectly, to discriminate in price between different purchasers of commodities of like grade and quality, where either or any of the purchases involved in such discrimination are in commerce, where such commodities are sold for use, consumption, or resale within the United States or any Territory thereof or the District of Columbia or any insular possession or other place under the jurisdiction of the United States, and where the effect of such discrimination may be substantially to lessen competition or tend to create a monopoly in any line of commerce, or to injure, destroy, or prevent competition with any person who either grants or knowingly receives the benefit of sucli discrimination, or with customers of either of them: Provided, That nothing herein contained shall prevent differentials which make only due allowance for differences in the cost of manufacture, sale, or delivery resulting from the differing methods or quantities in which such commodities are to such purchasers sold or delivered: Provided, however, That the Federal Trade Commission may, after due investigation and hearing to all interested parties, fix and establish quantity limits, and revise the same as it finds necessary, as to particular commodities or classes of commodities, where it finds that available purchasers in greater quantities are so few as to render differentials on account thereof unjustly discriminatory or promotive of monopoly in any line of commerce; and the foregoing shall then not be construed to permit differentials based on differences in quantities greater than those so fixed and established: And provided further, That nothing herein contained shall prevent persons engaged in selling goods, wares, or merchandise in commerce from selecting their own customers in bona fide transactions and not in restraint of trade: And provided further, That nothing herein contained shall prevent price changes from time to time where in response to changing conditions affecting the market for or the marketability of the goods concerned, such as but not limited to actual or imminent deterioration of perishable goods, obsolescence of seasonal goods, distress sales under court process, or sales in good faith in discontinuance of business in the goods concerned.

(b) Upon proof being made, at any hearing on a complaint under this section, that there has been discrimination in price or services or facilities furnished, the burden of rebutting the prima-facie ease thus made by showing justification shall be upon the person charged with a violation of this section, and unless justification shall be affirmatively shown, the Commission is authorized to issue an order terminating the discrimination: Provided, however, That nothing herein contained shall prevent a seller rebutting the prima-facie case thus made by showing that his lower price or the furnishing of services or facilities to any purchaser or purchasers was made in good faith to meet an equally low price of a competitor, or the services or facilities furnished by a competitor.

(c) It shall be unlawful for any person engaged in commerce, in the course of such commerce, to pay or grant, or to receive or accept, anything of value as a commission, brokerage, or other compensation, or any allowance or discount in lieu thereof, except for services rendered in connection with the sale or purchase of goods, wares, or merchandise, either to the other party to such transaction or to an agent, representative, or other intermediary therein where such intermediary is acting in fact for or in behalf, or is subject to the direct or indirect control, of any party to such transaction other than the person by whom such compensation is so granted or paid.

In short, the Robinson-Patman Act provides a cause of action for antitrust injury caused by sales of like commodities to similarly-situated customers at different prices. Historically, the courts have recognized two statutory defenses: first, that the price difference is cost-justified; second, that the lower price meets a competitor's price. Finally, in contrast to the Sherman Act's broad jurisdictional scope, the Robinson-Patman Act applies only to sales "in commerce."

4. See, e.g., R. BORK, supra note 1, at 382-85; P. AREEDA, ANTITRUST ANALYSIS 1050 (3d ed. 1981). 
antitrust argument. As a result, the LEA has significantly transformed price discrimination doctrine in recent years. It has monopolized our sense of what constitutes rational price discrimination doctrine. Although the LEA's concept of economic price discrimination is central to its own logic of antitrust analysis, this efficiency-based formulation fails in two significant respects. Not only is its explicit logic incoherent, but its values are inconsistent with antitrust's primary value of preserving competition. Yet behind these manifest failures lies an unstated consistency-a political economy of large conglomerate firms.

The second reason for focusing on the Robinson-Patman Act is its clearly marginal importance. Although no one disputes its position at the periphery of antitrust law, it is that very marginal position that is crucial for this article's analysis: Like the philosopher's interest in anomaly, the mathematician's work in extrema, or the literary critic's attention to King Lear's fool, this analysis uses the Act as a lever to raise questions of central significance to the body of antitrust analysis. In sum, it takes marginal position or anomaly description as centrally important because systems, models, and interpretive structures are defined as much by their limits-what they exclude-as they are by their domains-what they include. Thus, the Robinson-Patman Act provides a particularly good vehicle for examining the predicament of antitrust argument and the Law and Economics Approach's strategy for escape.

\section{B. Commentators and Critics: Trustees of Rational Argument.}

In the courtroom, antitrust argument produces material consequences: Wealth may be redistributed or personal freedom impaired. Trial and appellate argument seeks or opposes such practical change. Judges, who are the focal points for such argument, characteristically consider past decisions, the record in the case, and statutory construction. In short, not only must a court's decision seem fair or just, but its rationale must also pass muster. And while a litigant's antitrust argument must satisfy only one tribunal at a time, a judicial opinion faces multiple arbiters.

In scholarly journals, it is commentators and critics who judge judges. Although they engage in dialogues among themselves and offer guidance to legislatures and agencies, their traditional role casts them as acknowledged, though unseated, Lord Chancellors who assess the logic and propriety of judicial opinions. Clearly this institution also has something at stake: It shares the desire for change as a motivation for argu- 
ment. ${ }^{5}$ Far from the madding crowd of opposing counsel, witnesses, juries, and clients, the authors of antitrust treatises and journal articles purport to harmonize or synthesize antitrust argument. They summon us to perfect argument. Texts such as those by Posner, ${ }^{6}$ and Areeda and Turner, ${ }^{7}$ are seen as emerging from quiet deliberation with distanced learning in hand. Untouched by the need to resolve cases and controversies, these writings purport to offer expert testimony of antitrust argument. In turn, judicial opinion and agency guidelines reflect the pronouncements of these trustees of rational argument.

What is at stake is the market for antitrust argument, specifically, a particular submarket: Who supplies the analytical framework that gives shape to the phrase "price discrimination"? The largest institutional users of such argument-scholars, courts, the FTC, and the Department of Justice's Antitrust Division-now tend to deal with only one firm: the Law and Economics Approach. ${ }^{8}$ The consequences of these dealings are material. The LEA has monopolized an argument submarket whose product is a legal doctrine-price discrimination-by orchestrating a boycott of the Robinson-Patman Act. ${ }^{9}$ For example, the FTC used to

5. There is also something else at stake. Like all institutions, academe must justify its authority to maintain its viability. For an analysis of that dynamic in the context of the humanities, sec Ryan, Deconstruction and Radical Teaching, 63 YAle FrenCH STUD. 45 (1982). For studies of societal institutions as disciplining authorities, see the work of Michel Foucault, supra note 2.

6. R. Posner, ANtitrust LAw: AN Economic Perspective (1976) [hereinafter cited as ANTITRUST LAW].

7. P. AReeda \& D. Turner, ANTitrust Law (1978) [hereinafter cited as AReEDa \& TURNER].

8. The Law and Economics Approach takes as its ethical predicate the optimization of efficiency and thereby the maximization of consumer welfare. See, e.g. R. BoRK, supra note 1, at 10715 (arguing that antitrust should concern itself solely with allocative and productive efficiency); ANTITRUST LAW, supra note 6, at 9-23. By relentlessly promoting efficiencies, a market mechanism is purportedly free to generate goods and services consumers desire most, at the lowest prices. Thus, the most efficient firms in the most appealing markets survive to put scarce resources to their lighest and best use: the satisfaction of consumer desires. In sum, the raison d'etre for antitrust is seen as the preservation of efficient markets as the best arena for consumer exercisc of pure prcference. That is not to say that the LEA describes a unified approach. For example, the so-called Harvard School form of industrial organization and the Chicago School form of price theory do differ in some respects. One fundamental disagreement centers on the significance of barriers to entry. That disagreement involves attempts to reconcile a contradiction fundamental to antitrust doctrine. For a discussion of that contradiction, see infra notes 74-82, 512-18, and accompanying text. For an analysis of Posner's view of barriers to entry, see infra notes 377-512 and accompanying text.

9. This article applies the familiar Sherman Act doctrine of monopolization to this interrogation of antitrust argument. The Supreme Court's opinion in Standard Oil Co. v. United States, 221 U.S. 1, 62 (1911), first announced the rule of reason standard for judging monopolies. As Judge Learned Hand later reaffirmed in the landmark opinion of United States v. Aluminum Co. of America, 148 F.2d 416, 429-33 (2d Cir. 1945), big is not necessarily bad. Rather, something more must be proved in order to establish monopolization. In addition to demonstrating monopoly power, a plaintiff must offer evidence of some monopolizing conduct. See, e.g., Otter Tail Power Co. v. United States, 410 U.S. 363, 377-79 (1973) (refusal to deal). One recent commentary concludes that 
prosecute between fifty and sixty price discrimination cases annually, but it no longer vigorously enforces the Act. ${ }^{10}$ In similar fashion, the multivolume Areeda and Turner Antitrust Law treatise excludes the Act from what purports to be a comprehensive and exhaustive work; yet it uses a concept of price discrimination as a central explanatory concept for rationalizing antitrust analysis. ${ }^{11}$ Indeed, few of us these days teach or write about the statute; yet we continue to think in terms of price discrimination. ${ }^{12}$ In the larger context of antitrust argument, this doctrinal

the IBM antitrust cases have resulted in an even more stringent conduct requirement. Sullivan, Monopolization: Corporate Strategy, The IBM Cases, and the Transformation of the Law, $60 \mathrm{TEX}$. L. REv. 587, 637-38 (1982).

This article is inspired by, although not limited to, such doctrinal tenets. It can be seen as a study of a particular market-the market for price discrimination argument. A borrowing of antitrust doctrine, the "monopolization" metaphor, when applied to LEA theory, allows for a self-reflexive treatment of the rule of economic reason and its rhetorical strategies. By taking the form of which it speaks, this philosophical investigation of the LEA can avoid the philosophical centering of an economistic study. Thus, although an ethical and epistemological interest motivates this article, it uses the language of law and economics to pursue that interest. See, e.g., M. Foucault, THE Discourse on Language 215-38 (1972); J. DERR1DA, Structure, Sign, and Play in the Discourse of the Human Sciences, in WRITING AND DIFFERENCE 278 (1978). In other words, the language of the LEA-first "monopolization" and then terms like "marginal cost"-is used to test the very system that generates and depends upon that language. For one statement of the importance of analyzing the sociopolitical phenomenon of monopoly, see R. MIL1BAND, THE STATE IN CAPITAL15T SOCIETY 11-15 (1969). For an introductory analysis of the need to demystify language in order to empower social value debate, see J. HABERMAS, TOWARD A RATIONAL Society 62-80 (1970) (arguing that there must be a translation of the scientific terms of politics in order for the public to develop meaningful opinions). For treatment in more depth, see J. HABERMAS, THEORY AND PRACTICE 1-41, 253-82 (1973). The problem with most of such work is its own difficulty in escaping analysis which itself re-mystifles language.

Recent legal scholarship on law as interpretation includes Abraham, Statutory Interpretation and Literary Theory: Some Common Concerns of an Unlikely Pair, 32 RuTGERs L. Rev. 676 (1979); Brest, Interpretation and Interest, 34 STAN. L. REv. 765 (1982); Fiss, Objectivity and Interpretation, 34 STAN. L. REv. 739 (1982); Parker, The Past of Constitutional Theory-And Its Future, 42 OH10 Sr. L.J. 223 (1981); Law and Literature, 60 TEX. L. REv. 373 (1982); Legal Scholarship: Its Nature and Purposes, 90 YALE L.J. 955 (1981).

10. See R. Posner, The Robinson-Patman Act 31 (1976) [hereinafter cited as The RPA] (current FTC "policy of seemingly deliberate neglect"); see also 2 ABA SEC. ANTITRUST L., ThE RoBinson-PATMAN ACT xi (Monograph No. 4 1984) (low level of Robinson-Patman Act enforcement by FTC in last decade). Although Chairman Miller asserts that the Act is again an important part of Federal Trade Commission enforcement policy, his reference to 29 cases on the docket can paint a misleading picture. Interview with James $C$. Miller, III, Chairman, Federal Trade Commission, in E. FoX \& J. Halverson, Antitrust Policy in Transition: The Convergence of LAW AND ECONOMICs 115, 124 (1984). First, only one consent decree is on its way to the Commission. Id. Second and even more telling, the Commission's enforcement is founded in a new policy which is significantly different from traditional statutory interpretation. In particular, Miller recommends enforcement when it offers the most efficient way to get at monopoly or monopsony power. Id. This represents the Sherman Act standard of monopolization, rather than the lower Clayton Act and Robinson-Patman Act standards of competitive effect-a substantial lessening of competition. See infra notes 140-43 and accompanying text.

11. See AREedA \& TURNER, supra note 7 , at 3.

12. See infra notes $\mathbf{1 1 8 - 3 4}$ and accompanying text. 
monopolization is an illustration of a pervasive effort to boycott the LEA's rivals-a vision of Jeffersonian entrepreneurialism, a sense of fair competition, an ethic of equitable distribution, and a common law tradition. These rivals can collectively be called "populism." 13

This article investigates three strains of price discrimination scholarship, all of which take the LEA as their common point of departure. ${ }^{14}$ The works discussed not only share a fundamental belief in the LEA as the rational framework for antitrust argument but are also frequently cited in opinion and scholarship. ${ }^{15}$ Although their appearances overlap, the three strains do fall into a chronological succession of sorts. The earliest examples examined are book-length attempts to rationalize the Act. ${ }^{16}$ These early attempts at rationalization differ significantly from a second group of texts that are surprisingly charged with emotion. ${ }^{17}$ These efforts have engendered and encouraged a boycott of the extraeconomic argument symbolized by the Act. With the Act and all that it represents now excluded from the domain of rational analysis, recent scholarly writings develop a distinctly econounic form of price discrimination argument. ${ }^{18}$ The success of this third strain is founded in the normative and analytic attractiveness of the LEA's ground-allocative

13. More expansive treatment is not necessary for this article's treatment of the LEA's rivals. The point is simply that antitrust policy has traditionally encompassed a sense of political economy more diverse and complex than economic efficiency. For the standard descriptions of the sociopolitics of antitrust, see, e.g., C. KAYSEN \& D. TURNER, ANTITRUST Policy: AN Economic AND Legal ANAlysis 11-18 (1959); W. LeTw1N, LAW and EConomic Policy IN AMER1CA: The Evolution OF THE SHERMAN ANTI-TRUST ACT 68-77 (1965); F. SCHERER, INDUSTRIAL MARKET Structure ANd Economic Performance 11-12 (1970); Kaysen, The Corporation: How Much Power? What Scope?, in E. Mason, The Corporation IN MOdern Society 85-105 (1960); see also Brown Shoe Co. v. United States, 370 U.S. 294, 344 (1962) (Clayton Act intended to protect small, locally-owned business); Northern Pac. Ry. v. United States, 356 U.S. 1, 4-5 (1958) ("The Sherman Act was designed to be a comprehensive charter of economic liberty aimed at preserving free and unfettered competition.").

14. For recent scholarship taking a different approaeh, see L. SUllivan, ANTITRUST (1976); The Goals of Antitrust: A Dialogue on Policy, 65 Colum. L. REv. 363 (1965); Symposium on Antitrust Law and Economics, 127 U. PA. L. REv. 918 (1979); First, Book Review, 52 N.Y.U. L. REV, 947 (1977); Schwartz, Book Review, 128 U. PA. L. REV. 244 (1979). Regarding the RobinsonPatman Act in particular, see generally D. BAUM, THE RoBINSON-PATMAN ACT (1964); E. KINTner, A Robinson-Patman Primer (1971); W. Patman, The Complete Guide to the RobinSON-PATMAN ACT (1963).

15. This statement is based on anecdotal evidence, rather than any empirical enterprise.

16. Of course, numerous articles and books did appear earlier. For an exhaustive bibliography, see 1 ABA SeC. ANTitrust L., The Robinson-PATMAN ACT, at 159-78 (Monograph No. 4 1980).

17. Frederick Rowe portrays the Act as dangerously irrational. See infra notc 191. Such madness is taken as a sufficient predicate for exclusion from proper antitrust argument. Later, Robert Bork crowns the Act the "Typhoid Mary" of the antitrust laws. See infra note 162.

18. This is Thomas Kuhn's normal scienee. T. KuHN, THE Structure of Scientific Revolution (2d ed. 1970). Many of the responses are also economic. See, e.g., Harris \& Jorde, Antitrust Market Definition: An Integrated Approach, 72 CAL. L. REv. 3 (1984); Kennedy, CostBenefit Analysis of Entitlement Problems: A Critique, 33 STAN. L. REV. 387 (1981); Kenuedy \& 
efficiency. ${ }^{19}$ At first blush, its ethic of consumer sovereignty seems desirable, perhaps even neutral. ${ }^{20}$ In addition the LEA promises coherence by pledging to rationalize the inarket for price discrimination argument. It turns out that both ethically and logically, economic price discrimination ultimately does no better than its polymorphous predecessor. In some respects, it fares far worse.

\section{The Strain of Rationality: Politics and Price DISCRIMINATION}

Two decades after the passage of the Robinson-Patman Act, a steady flow of books began to take aim at the price discrimination statute. ${ }^{21}$ Among these works, the Report of the Attorney General's National Committee to Study Antitrust Laws 22 (hereinafter 1955 AG Committee Report) and a book by Corwin Edwards ${ }^{23}$ stand out and retain influence. $^{24}$ Each envisions its mission as doctrinal reconstruction. While the 1955 AG Committee Report concerns itself with the panorama of antitrust laws, Edwards deals only with the Robinson-Patman Act. Nonetheless, each articulates themes that remain central to our characterization of the Act. Although both expound at length on numerous issues in varying institutional contexts, this subsection will focus on each work's original position and fundamental structure.

\section{A. Edwards and the Politics of Discrimination.}

Edwards' Price Discrimination Law is a field study of Federal Trade

Michelman, Are Property and Contract Efficient?, 8 HofsTRA L. REv. 711 (1980); 1982 Merger Guidelines, 71 CAL. L. REV. 280 (1983).

19. For an excellent introduction to the logic and ethical dimensions of allocative efficiency, see Posner, Utilitarianism, Economics, and Legal Theory, 8 J. LEGAL STUD. 103 (1979); Change in the Common Law: Legal and Economic Perspectives, 9 J. Legal STUD. 189 (1980); Symposium on Efficiency as a Legal Concern, 8 HoFSTRA L. REV. 485 (1980).

20. Its success also emerges from a reversal of efficiency's relationship to our concept of competition. According to the LEA, competition must serve efficiency in order to have any value. See infra notes 418-27 and accompanying text.

21. See D. Baum, supra note 14; C. Edwards, The Price Discrimination Law: A Review of Experience (1959); J. Palamountain, The Politics of Distribution 188-234 (1955); W. Patman, supra note 14; A. SAWyer, Business Aspects of Pricing UNDer the ROBINSON-PATMAN ACT (1963).

22. RePORT OF the AtToRney General's National COMmittee to StUdy ANTtTRust LAWS (1955) [hereinafter cited as 1955 AG COMMITTEE REPORT].

23. C. EDWARDS, supra note 21.

24. It is striking how little contemporary Robinson-Patman Act scholarship departs from or adds to these two endeavors. See, e.g., P. AREEDA, supra note 4, at $1051 \mathrm{n} .2$ (citing C. EDWARDS, supra note 21); id. at $4 \mathrm{n} .9$ (citing 1955 AG COMMTTIEE REPORT, supra note 22). Moreover, the 1955 AG Coinmittee Report strongly influenced Posner's formulation of the collusion problein. Compare ANTrTRUST LAW, supra note 6, at 55-71 with 1955 AG COMMTTEE REPORT, supra note 22 , at $315-42$. 
Commission (FTC) price discrimination litigation. ${ }^{25}$ After a brief introductory chapter, Edwards presents an overview of the Act's legislative history. ${ }^{26}$ The study next describes FTC enforcement in general terms, ${ }^{27}$ and then devotes fourteen chapters to a specific account of Commission action. ${ }^{28}$ Finally, Edwards concludes with an appraisal of the Act and some policy suggestions. ${ }^{29}$

This subsection analyzes three significant aspects of the study. It begins by describing the first chapter's strategy of differentiating political and economic discrimination. One consequence of differentiation is an image of political discrimination as illegitimate and incomplete. A subsequent fable of juncture reinforces the asserted superiority of the economic form. Edwards' portrayal of the FTC is then critiqued in terms of the foregoing structure-the ideological dissonance struck by the political/economic split. Finally, the study's concluding image of politics is examined. Edwards' antinomy-political and economic discriminationpervades current price discrimination scholarship. Thus it offers a salient point of departure for investigating commentators' and critics' participation in this monopolization of price discrimination argument.

1. The Statute: Politics or Economics? Edwards introduces discrimination as an idea with "shadowy origin[s] in the social and legal preconceptions of democratic society." 30 Nondiscrimination requires equal treatment by political or judicial authorities. ${ }^{31} 1 \mathrm{t}$ further implies equal treatment by private persons with power over the political rights and economic opportunities of their fellows. ${ }^{32}$ From the outset, Edwards asserts two categories of discrimination structured in two dimensions. One set requires public actors in their political or judicial duties to treat others equally; the second set implies that private actors in their political or economic activities ought to treat others equally. Thus one dimension of distinction is the public or private status of the actor; the other is the judicial, economic, or political range of the activity. Because only public

25. C. EDWARDS, supra note 21, at xiti. A professor of economics at the University of Chicago at the time of the book's publication, Edwards had been a long-time staff member of the FTC. Id. at vii.

26. Id. at 21-53.

27. Id. at 66-86. FTC enforcement is seen as politically driven. See infra notes $59-73$ and accompanying text.

28. C. EDWARDS, supra note 21, at 92-616. The account of Commission action is more or less based on the organization of the legislative history chapter. They do not match precisely but overlap, affording comprehensive coverage.

29. Id. at 617-59.

30. Id. at 1 .

31. Id.

32. Id. 
officials act judicially and only private parties act economically, it seems that the perception and labeling of behavior can be crucial: If behavior is economic, then it is by definition private and no compulsion for equal treatment attaches. ${ }^{33}$ Furthermore, while economic conduct necessarily implies private action and judicial conduct necessarily implies public action, political conduct can either require or imply equal treatment, depending on the status of the actor. Politics undoubtedly blurs categories. Accordingly, since argument fitted to economic or judicial vestments produces a clear silhouette, not only our strong desire for analytic clarity but also an individualist ideological imperative against compulsion encourages us to view private conduct as economic rather than political: An economic approach appears to outline the best course for both convincing logic ${ }^{34}$ and personal autonomy. ${ }^{35}$

Edwards seeks to fill in the outline by weaving an argument the strongest thread of which is a preference for the economic idea of discrimination. ${ }^{36} \mathrm{He}$ offers a juxtaposition of the shadowy origin of "political thinking" about equal treatment and the inheritance from classical economists of a "more precise but less comprehensive idea" of such equality. ${ }^{37}$ Furthermore, the choice makes even better sense in the context of the marketing of goods, because there "the economic idea is broader than the political idea." 38 In this narrower context, the economic notion of discrimination not only remains more precise, but also grows broader than the political idea. By focusing on cost/price relations, the economic idea of discrimination can encompass both equality

33. A comparable analysis still applies to the identity of antitrust actors. See, e.g., City of Lafayette v. Louisiana Power \& Light Co., 435 U.S. 389, 413 (1978) (under the state action doctrine of Parker v. Brown, 317 U.S. 341 (1943), acts of a state government or its subdivisions pursuant to proper state authorization are immune from the antitrust laws); Areeda, Antitrust Immunity for "State Action" After Lafayette, 95 HARV. L. REV. 435 (1981).

34. See, e.g., Kitch, The Intellectual Foundations of "Law and Economics," 33 J. LEGAL Educ. 184 (1983). But see, e.g., Michelman, Reflections on Professional Education, Legal Scholarship and the Law-and-Economics Movement, 33 J. LEGAL EDuc. 197 (1983); Kelman, Misunderstanding Social Life: A Critique of the Core Premiscs of "Law and Economics", 33 J. LEGAL Educ. 274 (1983).

35. The classic statement is F. HAYEK, THE ROAD TO SERFDOM (1944) (political freedom is dependent upon economic freedom); see also Stigler, Wealth, and Possibly Liberty, 7 J. LeGal STUD. 213 (1978) (personal liberty analyzed in terms of economic endowment). But see M. FoucaulT, POWER/KNOWLEDGE, supra note 4, at 78-108 (politics are not purely a function of the economic system).

36. For example, FTC enforcement is criticized for its political character. See infra notes 59-73 and aecompanying text.

37. C. EDWARDS, supra note 21, at 1-2. Certainly a classical inheritance is preferable to a dark, unknowable beginning. Rationality demands precise ideas, not vague preconceptions. Clearly this scenario describes Edwards' desire to disdain the political category in favor of the economic.

38. Id. at 2 . 
and inequality, ${ }^{39}$ whereas political discrimination is concerned only with equality: "According to the political idea, discrimination is found only in unequal treatment.... Undue equality is never subject to criticism." 40

But the two propositions quoted make sense neither descriptively nor analytically. First, political sentiments and legislation often address undue equality. ${ }^{41}$ In a landmark opinion that Edwards later discusses at length, the Supreme Court affirmed the FTC's specific concern for undue equality under the price discrimination statute by holding Morton Salt's equal offer of volume discounts to all buyers discriminatory because only a few large buyers could take advantage. ${ }^{42}$ Second, any analytic distinction grounded in an assertion that it is possible to discuss inequality without considering equality is simply wrong. The process of evaluating inequality itself calls for judgments of equality. ${ }^{43}$ Edwards' image of political discrimination as a semi-rational enterprise is found in neither fact nor fancy.

Edwards also claims that economic discrimination's cost/price focus includes a larger and thus better population of economic actors than the political idea's equal status-based logic, because cost/price variances can encompass a heterogeneous set of buyers or sellers, while the political notion of "similarly situated" cannot. ${ }^{44}$ In particular, when the political idea is applied to the marketing of goods, "only the buyers or the sellers of a particular commodity [in competition with each other] are similarly situated." 45

Although the political idea of discrimination encompasses much more than statutory price discrimination, the quoted statements seem to equate the two-at least in a marketplace context. ${ }^{46}$ But if an unspoken equation between political discrimination and the Act now underlies the narrative, then the political idea of discrimination has been radically particularized. Whether in a marketing context or in broader application, the myriad facets of political discrimination surely refiect more than the

39. That is, by looking at cost/price ratios, an equal price to two customers can be unequal if costs are unequal. Id. at 2-3.

40. Id. at 2.

41. For example, flat-rate taxes such as sales taxes are commonly regarded as regressive.

42. FTC v. Morton Salt, 334 U.S. 37, $42-43$ (1948). Edwards sees the Robinson-Patman Act as founded in a political, not an economic, idea of discrimination. C. EDWARDS, supra note 21 , at 2.

43. If a judge were instructed to find only equality or only inequality in all cases, then she would not be engaged in something that we would recognize as judging.

44. C. EDwARDS, supra note 21 , at 2 .

45. Id.

46. For an interesting treatment of price discrimination in differing legal contexts, see Dam, The Economics and Law of Price Discrimination: Herein of Three Regulatory Schemes, 31 U. CH1. L. REV. 1 (1963). 
Act, whatever its given interpretation. ${ }^{47}$ Further, Edwards' apparent equation of the political idea of discrimination with the statute undermines his assertion that the economic idea enjoys a proprietary claim to precise analysis: a cost/price focus can no longer distinguish the economic idea from the political one, the Robinson-Patman Act, whose cost-justification defense derives from a classical economic image of cost/ price proximity very much like the version that Edwards describes. ${ }^{48}$ Perhaps it is the recognition of that danger-the statute's claim to the precision of the economic idea-that motivates the implicit equation of the political idea and the statute. Edwards wants to characterize the statute as political, but that very characterization undermines the purported distinction between the political and economic ideas of discrimination. Despite the veiled reference, he cannot have it both ways.

After dividing discrimination in two and evaluating the results as separate political and economic enterprises, the first chapter chronicles their intersection. Edwards refers to the economic idea's first joint venture with its twin in "medieval conceptions of the just price." 49 Political discrimination is described as an idea superimposed upon an autonomous real-world regime of commercial affairs. ${ }^{50}$ Thus, although discrimination is initially described as founded in the preconceptions of a democratic society, the political form is now described as an intervenor in an economic status quo. Somehow an image of unfettered business as social reality now historically, logically, or ethically precedes this once-original vision of a democratic society. Furthermore, Edwards asserts that this vagrant political idea of fairness ${ }^{51}$ has recently "borrowed" part of the economic notion of discrimination-the cost-justification defense. 52 Thus Edwards' account jumps from the Middle Ages to 1936 without even a word about the intervening 500 years. This idiosyncratic historical journey proves or describes little beyond a desire to characterize the

47. Discriminatory hiring or pay practices are two obvious examples of extra-Act forms of discrimination.

48. C. EDWARDS, supra note 21 , at 2-3.

49. Id. at 3. By "just" price, does Edwards mean only price or does he mean fair price? If the former, what of classical Greek notions of distributive justice? See, e.g., 5 AR1STOTLE, Nichomachean ETHics *1131a-b, ("justice" viewed in terms of proportionality).

50. C. EDwaRDS, supra note 21 , at 3 . The term used to describe the application repcats the imposition: "politico-economic" rather than econopolitical legisiation. Id.

51. Although Edwards does not use the term "vagrant" to describe the political idea of discrimination, its undercapitalization is implied in the borrowing from its economic counterpart. For an explicit assertion that fairness amounts to little more than antitrust doctrinal vagrancy, see $P$. AREeDA, supra note 4, at 28 (that "vagrant claim"-fairness). But see id. at 55 (fairness of criminal brand of antitrust violators).

52. C. EDwARDS, supra note 21, at 3. Presumably, cost-justification means proof of just price. Hence, the political notion of fair price includes more than only price. It might, for example, include cost. Uitimately, "just" means not merely "only," but also "fair." 
economic idea of discrimination as not only different from the political, but also better: first-born, legitimate, precise, comprehensive, and wellcapitalized.

The first chapter's mission to establish two different categories of discrimination is less than successful. This failure is particularly salient because the "problem and the plan" of the 700-page enterprise emerges from the proposed distinction. ${ }^{53}$ Thus the Edivards text from the outset suffers from the LEA's strain of rationality: an impulse to discipline argument within the contours of an economic logic, then a desire to claim exclusive ownership of logic's power. In the language of antitrust, this dynamic can be described as an intent to monopolize. ${ }^{54}$

The first chapter concludes with a look at the Act's legislative history. Although depicted as a legislative blurring of the focus of the Clayton Act, ${ }^{55}$ the Act is described as making some sense and offering some hope of improving competition. ${ }^{56}$ Edwards poses a series of questions: Are the effects of more small competitors static prices or more vigorous competition? Cheaper goods or more expensive?57 By the end of the book, Edwards concludes that "competition among the few tends to be weak competition."58

2. The FTC: Politics or Expertise? After a fourteen-chapter description of FTC and court enforcement of the Act based on such open questions, Edwards offers an appraisal and policy suggestions. ${ }^{59}$ His review is mixed. On the one hand, cases that arose confirmed the congressional belief that there were problems of price discrimination significantly related to competition. ${ }^{60}$ Many large buyers did enjoy noncost-based advantages, suggesting that market power, although less than monopoly power, can be significantly anticompetitive. ${ }^{61}$ In general, the Act met the problem successfully, as the pressure of big buyers on sellers diminished. ${ }^{62}$ On the other hand, because fear of FTC prosecution prevented firms from cutting prices selectively or locally, competition was nega-

53. Id. at 1-5.

54. See supra note 9.

55. Edwards believes that the proper focus is primary-line concerns: injury to competitors. See

C. EDWARDS, supra note 21, at 5 .

56. Id. at $15-16$.

57. Id. at 15 .

58. Id. at 620 .

59. See id. at $617-35,656-57$.

60. See id. at 619.

61. See id. at 620. For example, Edwards sees the power of The Great Atlantic \& Pacific Tea Co. as clearly anticompetitive. See id. at $619 \& \mathrm{n} .1$ (power of A\&P led to passage of the RobinsonPatman Act).

62. See id. at 622 . 
tively affected. ${ }^{63}$ To punctuate an empirical picture of indeterminacy, the evaluation concludes that efficiency effects-the primary concern of the LEA-were mixed. ${ }^{64}$

Edwards observes that FTC proceedings, rather than private suits, were the dominant force in formulating legal and policy issues, ${ }^{65}$ and that the Commission played a leading role in statutory enforcement and doctrinal development. Such preeminence, Edwards suggests, befits an institution established and perceived as an economic expert. ${ }^{66} \mathrm{He}$ argues, however, that agency activities distorted the Act's proper focus. ${ }^{67}$ In particular, the study finds that almost half of all Commission orders involved relatively unimportant section 2 (c) brokerage cases. ${ }^{68}$ Although straightforward discriminatory pricing is presumably the statute's primary target, its prosecution under section 2(a) received less attention. ${ }^{69}$ Why this particular allocation of enforcement resources?70 Because, Edwards concludes, brokerage cases are easy. The FTC need only prove that a payment constituting a brokerage commission was improperly made between parties to a transaction. ${ }^{71}$ Questions of competitive injury, cost-justification, and meeting competition are not considered. In the strictest sense, section 2(c) offenses are illegal per se. Moreover, although Congress' paramount concern was with big buyers, the Commission virtually ignored section 2(f) buyer liability cases. ${ }^{72}$ The Commission had an incentive to bring brokerage cases, because they were simple, inexpen-

\section{Id. at 630 .}

64. Id. at 628-29. For example, though some firms perceived the Act as an obstacle to marketing experimentation, others were encouraged to pay more attention to cost-price relations. Id.

65. Id. at 67-68. Edwards notes that the presence of juries made private suits less effective. See id. at 67 n.7, 600 n. 27 .

66. See id. at 67.

67. Id. at 70 .

68. Id. at 68-70. "Brokerage" describes one form of price discrimination in favor of large buyers. Pejoratively called "dummy brokerage," such discounts take the form of payments for a brokerage or middleman function though no independent broker is involved. While such payments can be justified by viewing the large buyer as an integrated firm that does its own brokerage, section 2(c) does not permit such payments. See 15 U.S.C. $\S 13$ (c) (1982). In short, such arrangements are treated as straw middleman cases. See C. EDWARDS, supra note 21, at 46-48, 92-152.

69. Only slightly more than 32 percent of all Commission orders involved price discrimination by sellers. C. EDWARDS, supra note 21, at 69.

70. Edwards states that there is "no reason to believe that . . . [brokerage] has constituted the principal threat to competition evident among discriminatory practices." Id. at 70-71.

71. Id. at 71. See 15 U.S.C. \$13(a) (1982).

72. C. EDwARDS, supra note 21 , at 72 . Section $2(f)$ provides that "it shall be unlawful for any person engaged in commerce, in the course of such commerce, knowingly to induce or receive a discrimination in price which is prohibited by this section." 15 U.S.C. $\S 13(\mathrm{f}$ (1982). See Great Atl. \& Pac. Tea Co. v. FTC, 440 U.S. 69, 84-85 (1979) (buyer liability derivative, so that buyer who accepted the lower of two prices competitively offered from seller cannot be liable under section 2(f)). 
sive, and provided an "impressive statistical total." 73 Edwards concludes that this agency of experts yielded to the pressures of politics. Fiscal politics both obstructed the rational development of price discrimination doctrine and distorted the proper allocation of fiscal resources.

Edwards' disapproval of the Act's doctrinal development is quite specific: He criticizes the standards for finding competitive injury. In primary line cases (injury to competitors), a discrimination in price causes cognizable injury if it diverts business from a competitor to the defendant. ${ }^{74}$ Edwards contends that this diversion standard is inappropriate because "successful competition necessarily diverts business from rivals." 75 In secondary line cases (injury to customers), injury is simply inferred from a substantial price difference. ${ }^{76}$ Edwards calls this doctrine an inappropriate enforcement of equal opportunity for all buyers. ${ }^{77} \mathrm{He}$ argues that the guiding principle at both primary and secondary levels should be the curbing of "manifestations of concentrated economic power."78 In other words, the appropriate focus at both levels is competition, not competitors. ${ }^{79}$

This concern for competitors reflected in injury definitions of diversion and equal opportunity rehearses a fundamental contradiction between private property and competition: Both FTC injury doctrines serve a proprietary interest in maintaining the status quo, in protecting competitors from the inroads of competitive change..$^{80}$ Yet both seek to preserve the image of competition as a densely populated meritocracy and to enforce equal treatment as the engine for fair change. Thus it is no accident that Edwards sees section 2(c) brokerage cases as the Commission's most problematic and least acceptable enforcement effort. Because they are automatic-injury cases, they raise the ideological contradiction by uncovering the meritocratic ideal's dependence on and denial of equal opportunity. Because no proof of injury is necessary, brokerage offenses are presumed always to injure competition. ${ }^{81}$

73. C. EDWARDS, supra note 21 , at 71 .

74. See id. at 637 ; see also id. at 518-31 (elaborating standards of liability in primary-line cases).

75. Id. at 637 .

76. Id. at 532 .

77. Id. at 638-39.

78. Id at 642 .

79. See infra notes $269-92$ and accompanying text.

80. See supra note 8.

81. They do in the sense that this particular sort of discrimination usually favors large buyers who bypass the traditional intermediate brokerage function. It is small buyers who tend to purchase from middlemen who buy in quantity and sell in odd lots. In practical terms, large buyers categorically receive a lower price. At the same time, a requirement of equal wholesale price denies large buyers the benefit of their efficiencies and ignores costs attendant to their in-house brokerage functions. Competition on the merits is hindered. 
The contradiction is encapsulated in the doctrine of enhancing competition by protecting competitors. Competition is seen as the proper mechanism for change, for redistribution; protecting competitors from price discrimination discourages change, discourages redistribution. The doctrine appears self-destructive. Identifying the proper focus as competition and not competitors, Edwards seeks to resolve the dilemma by denying a relationship between serving competition and preserving competitors. But he has already concluded in the first chapter that competition among the few tends to be weak competition. Moreover, Edwards' disapproval of FTC enforcement and of its doctrinal development does not even acknowledge a contradictory relationship between competitors and competition, much less seek to resolve it. Grounded in the first chapter's scheme of separate economic and political categories, his analysis addresses only economic concerns, not political or cross-categorical ones. Further, he has already limited the FTC's proper scope to the economic sphere: both the statutory injury doctrines and automatic-injury brokerage cases cause redistributions of customers, sales, and profits. $\mathrm{Re}$ distribution falls into the category of politics, not economics. ${ }^{82}$ As such, Edwards would argue that they are inappropriate concerns. Instead, the Commission should focus on efficiency matters, on improving competition, not political matters. The FTC has not honored this legacy of economic logic in either its choice of cases or its development of price discrimination doctrine. Instead, it has engaged in the categorically inappropriate practice of politics.

Thus Edwards' faith in economic rationality and distrust of political logic and process insulates some significant questions from inquiry. Further, that faith enforces its own strict structure of expectations and interpretations. For example, despite the purely political motivation Edwards ascribes to the FTC's prosecution of section 2(c) brokerage cases, such fiscal preoccupation can also be viewed as economically rational-it can also represent a transaction motivated by the desire to maximize exchange value. ${ }^{83}$ The FTC's institutional aim of maximizing "revenues" by producing the services that buyers-here, the House and the Senatevalue most, fits the model of economic rationality. But the first chapter's categorization scheme has already established that rational policymaking can emerge only from economic logic. Because Edwards observes unac-

82. The separation of political economy into politics (distributional concerns) and economics (allocative concerns) suggests, erroneously, that the two can be both analyzed and practiced separately. See, e.g., A. OKun, Equality and EfFiciency: The Big Tradeoff (1975); Horwitz, Law and Economics: Science or Politics?, 8 HoFSTRA L. REv. 905 (1980) (brief historical analysis of division between distributive and allocative concerns).

83. See Stigler, The Theory of Economic Regulation, 2 Bell J. EcoN. 3 (1971) (describes firms as buyers in a market for government regulation). 
ceptable docket and doctrine development, he concludes that the practice must be purely political. Thus the study need not confront the possibility that economic rationality can be undesirable logic. Instead, based on the first chapter's scheme, the study can conclude that the FTC sold its inheritance of economics for the currency of congressional appropriations. Edwards' studied blindness to the Commission's economic rationality allows him to frame his policy suggestions in terms of economic logic without questioning such logic's multiplicity. The mutually exclusive categories of economics and politics are preserved. Rationality still presides over the private domain of economics.

3. Politics and Rationality. If the Commission does not purge itself of political sympathies, can the political process be trusted to ameliorate the statute's shortcomings and the agency's failings? Of course not. ${ }^{84}$ To corroborate that distrust, the final chapter observes in the practice of politics not only an unacceptable irrationality, but also an indigenous form of treachery. Edwards contends that the subject matter of price discrimination is so complex as to be misunderstood when viewed in political terms or in a political arena. ${ }^{85}$ Further, the actions of politicians are "exceptionally unpredictable" 86 because they are saboteurs; 87 their milieu is conflict. Accordingly, matters of such importance as clarifying the statute should be left to the temperate rationality of economic experts. ${ }^{88}$ In contrast to the intellectual inheritance that supports economic rationality, shadowy origins and uninformed struggle prevent even the possibility of political reason.

Edwards concludes with a parable of irrationality. Should temperature become a political issue, the objectives of rival factions would be boiling point and zero. Each group would advocate an extreme position. Yet the clash of these "zealots," Edwards notes, "often produces a compromise at something like an acceptable temperature." 89 This parable raises two issues; Edwards ignores the first and appears to resolve the second. First, both boiling point and zero can be reasonable temperatures for certain purposes. Edwards does not recognize this possibility because it requires the conjunction of zealotry and rationality. In his scheme, they cannot cross, because one resides in politics, the other in economics. A politican argues zealously, not rationally. Second, can Ed-

84. See C. EDWARDS, supra note 21, at 634-35 (arguing that congressional action, influenced by conflicting political interests, would be unpredictable).

85. Id.

86. Id. at 633-35.

87. Id.

88. Id. at 634-35, 656-57.

89. Id. at 657 . 
wards then conclude that there are simply no rational legislative acts? Apparently not. Despite the passionate pursuit of demagogic objectives, despite fervent devotion to extremist causes, Edwards concedes that the political process somehow often produces "something" that looks like a rational result. 90 Yet, Edwards warns, such rational products should not mislead us, because they are only appearances. ${ }^{91}$ Refusing to deal with logical propositions generated by an illogical process, the study calls for a trustworthy process derived from economic rationality-a program that, like the original Zealot sect's anti-Romanism 2000 years ago, is founded in profound distrust of the existing political order. ${ }^{92}$ But here, Edwards prefers a theocracy of a different sort, one founded in another final authority-the disciplined reason of economics.

\section{B. The 1955 AG Committee Report: Price Discrimination and the Rule of Reason.}

Whereas Edwards' political image of a rationally uncontrollable zealotry blurs the categories of public protection and private implication of rights, the 1955 AG Committee reports no such boundary problem. Rather, it points out that it was able to perform its study "completely untrammeled by direction from any public or private source." 93 The Report's Letter of Transmittal announces an uncompromisingly neutral position beyond the reach of both spheres. ${ }^{94}$ It desires and purports to be neither public nor private. ${ }^{95}$ Yet this committee was composed of lawyers and economists-representatives of both categories' rational agencies. 96

Nonetheless, the Report does acknowledge a dangerous probability of politics in its statement that the "aim in selection was to gather men who reflect interacting views on issues of antitrust policy."97 Whether or not the dividing lines are Edwards' categories, the Committee fully in-

90. Id.

91. Id. In other words, "the clash of zealots often produces a compromise something like an acceptable temperature." Id. (emphasis added); see O. BARField, SAVING THE APPEARANCES 1521 (1965) (no test for scientific rationality can proceed beyond evaluating appearances).

92. C. EDWARDS, supra note 21, at 657 . Believing that submission to Roman oceupation meant forsaking their religious beliefs, the Zealot faction organized a revolt in Northern Galilee against the Roman census in 6 A.D. See J. Noss, MAN's Religions 562 (3d ed. 1967); 2 OXFord ENGLISH DictionARY 3868 (Compact ed. 1971).

93. 1955 AG COMMITTEE REPORT, supra note 22, at iii.

94. Id.

95. Edwards' structure would deny that very possibility: An enterprise can be either one or the other, or both, but it cannot be neither. If both, it is political.

96. Still, would not Edwards call the additive consequence of mixing public and private categories the onset of politics?

97. 1955 AG COMMITTEE REPORT, supra note 22, at iv. 
tended to confront questions of policy-political questions. Indeed, the Committee points out that each section of the Report was a product of several months' "rigorous debate." 98 Moreover, strong dissents 99 punctuate most of those areas. Is the Committee positing a distinction between political institutions and political practices? If it is, then perhaps only such institutions need be avoided. For its political practice has apparently been depoliticized by the rigor of its debates. The implied distinction seems to deny not only that all members brought with them commitments shaped by their institutional experiences, but also that the entire Committee worked directly with several public agencies. ${ }^{100}$ Further, even if external political connections can somehow be severed, the distinction fails because members' vigorous advocacy, their exchange of "interacting views," certainly pitted interests against one another. In either sense, what could the Committee's policy debate have been but politics? Apparently, rational or rigorous policy debate can be neutral, an exercise in expertise. Politics, on the other hand, goes beyond the limits of reason. Must policy colloquy then be given up to experts? ${ }^{101}$ At least in antitrust policy debate, the 1955 AG Committee Report seems to suggest exactly that.

The Committee's matrix for rationality and the Report's "central core" is a "modern view of the Sherman Act [that] can start with Standard Oil Co. of New Jersey v. United States." 102 According to the Committee, the opinion's rule of reason "clarified prior doubts about the relationship between the Sherman Act and the common law, and defined the connection between Section 1 and Section 2 offenses." 103 For those who have read Justice White's Standard Oil opinion, claims of clarification and definition are unexpected. Indeed, the opinion's opacity is legendary. ${ }^{104}$ Nonetheless, the Report declares that earlier controversies over the opinion's reasoning "have receded into history." 105 Apparently, the Report's central tenet is not the opinion's modern view of the 1890 legislation, but rather a modern view of the opinion: "Review of that

98. Id. at $\mathrm{v}$.

99. Those dissents were usually articulated by Professor Louis B. Schwartz. See, e.g., id. at 166-67.

100. Id. at $\mathrm{v}$ (including the Departments of State, Commerce, Defense, and Labor).

101. Edwards prefers experts. See supra notes $82-92$ and accompanying text. $C f_{\text {. }}$ J. Habermas, TOWARD A RATIONAL SOCIETY, supra note 9 (to function rationally, a society must make its decisions in the light of open exchange between the technical logic of experts and the legitimating power of politics).

102. 1955 AG COMMITTEE REPORT, supra note 22, at 5 (citing 221 U.S. 1 (1911)).

103. Id.

104. Areeda excerpts the 13,000 word opinion in less than two pages. P. AREeda, supra note 4, at 148-49; see also 1955 AG COMMITTEE REPORT, supra note 22, at 5-8.

105. 1955 AG COMMITTEE REPORT, supra note 22, at 5. 
case's analysis in the light of modern developments, rather than old debates, helps restore perspective."106

At least three questions emerge: First, what debates are discounted by virtue of their age? Second, what modern developments shed new light on that dim opinion? Finally, what perspective is thereby restored?

All three inquiries can start from a clear consensus that Standard Oil stands for the proposition that monopoly is not illegal per se. ${ }^{107}$ That is, the existence of monopoly power does not by itself prove the offense of monopolization; something more, such as predatory pricing or a refusal to deal, ${ }^{108}$ must be proved to establish an unreasonable restraint of trade. ${ }^{109}$ The Report distinguishes between legal and economic formulations of the monopoly problem. Instead of an economic analysis of an industry's performance, "here as in all other phases of the law, legal responsibility is individual." 110 Each market participant is held accountable only for its behavior, not for its own success or its industry's failure. Although enhanced by economic analysis, legal concerns clearly dominate the Report. ${ }^{111}$

The Report's price discrimination section ${ }^{112}$ takes the legalistic approach of statutory reinterpretation and critiques of court and FTC opinions. ${ }^{113}$ For example, the Committee cites Automatic Canteen Co. $v$. $F T C^{114}$ for the definition of a section 2(b) prima facie case: "It refers not to any discrimination, but only to discriminations affirmatively prohibited when causing the adverse market effects described in [section] 2(a) and unlawful unless justified by the seller through one of the several defenses." 115 The concern here is a lawyerly one-making sense of a "procedural text" to guide administrative and judicial proceedings. ${ }^{116}$ "The Report also cites Automatic Canteen to support the proposition that to resolve the dilemma of choosing between irreconcilable economic theories which collide when the Sherman Act meets the Robinson-Patman

106. Id. at 5-6.

107. Id. at 11 .

108. See, e.g., Otter Tail Power Co. v. United States, 410 U.S. 366, 372-75 (1973) (refusal to deal); Standard Oil Co. v. United States, 221 U.S. 1, 43, $75-77$ (1911) (predatory pricing).

109. 1955 AG COMMITTEE REPORT, supra note 22, at 11.

110. Id. at 340 .

111. This is especially evident from the emphasis upon the doctrinal development of the case law. See id. at 388 (E.V. Rostow's concluding statement of partial dissent). The only significant deviation is the discussion of perfect and workable competition and monopoly. See id. at 315-42.

112. Id. at 155-221.

113. Even economist J.M. Clark's dissent comments in those terms. Id. at 219-20.

114. 346 U.S. 61 (1953).

115. 1955 AG COMMITTEE REPORT, supra note 22, at 163.

116. $I d$. 
Act, the former should take precedence. ${ }^{117}$ Here, the analysis allows no balancing of procompetitive and anticompetitive effects, no questioning of purpose. Rather, the ranking required by this rule of reason renders the price discrimination statute unreasonable per se. To evaluate the Report's resolution of the statutory dilemma, we must return to the three questions earlier posed.

1. Rule of Reason: Old Debates Discounted. First, what old debates about Standard Oil ought to be buried? The Report recounts one long-lived controversy centering on the imposition of the rule of reason. As early as 1911, the opinion was attacked for its promulgation of a doctrine neither consistent with prior opinion nor necessary to resolve the case. ${ }^{118}$ In other words, although the oil trust could be found to have violated the statute under the settled standard of per se illegality, ${ }^{119}$ the Court propounds the rule of reason, declaring that the Sherman Act, despite its language of universal condemnation, proscribes only unreasonable conduct. ${ }^{120}$ The opinion ignores the text of the statute-denouncing "[e]very contract . . . in restraint of trade" and "[e]very person who shall monopolize,"121_which makes no mention of "reasonable" or "unreasonable." Nevertheless, a close reading of the opinion uncovers an adequate argument that proscribing every instance of such conduct is neither desirable nor possible:122 All contracts restrain trade to some degree. An agreement to buy today's supply of oil from $A$ is also an agreement not to buy it from $B$. Do we make a judgment about the degree of restraint or simply condemn all contracts? ${ }^{123}$ A unanimous Court declared that such a choice must be made and that the pertinent criterion is the reasonableness of the restraint. The opinion has now survived nearly three-quarters of a century. Perhaps the problem has re-

117. Id. at 131-32.

118. See A.H. Walker, The "UnReasonable" Obiter Dicta of ChiEf Justice White in THE Standard Oil CASE 1, 2-13 (1911) (Prior cases established that the word "unreasonable" was not implied in the Sherman Act as a limitation upon the word "restraint." Justice White's inference of the word "unreasonable" was not only a departure from precedent, but also unnecessary, because the Court could have found monopolization under the earlier established statutory constrution.).

119. See, e.g., Northern Securities Co. v. United States, 193 U.S. 197, 325 (1904) (describes trust as Sherman Act section one combination and thus as falling within doctrinal category of per se illegality).

120. See P. AREEDA, supra note 4, at 50.

121. Sherman Act, ch. 647, $\S \S 1-2,26$ Stat. 209, 209 (1890) (codified as amended at 15 U.S.C. $\S \S 1-2$ (1982)) (emphasis added).

122. Standard Oil, 221 U.S. at 64-68.

123. Of course, another jurisprudential possibility is a focus on "restraint," rather than on "every contract." See id. at 86-90 (Harlan, J., concurring in part and dissenting in part) (asserting the use of a "restraint" reading rather than an "every contract" reading). 
ceded into history, even if its recollection troubles us for a moment. ${ }^{124}$

Yet the Report itself reopens the Standard Oil debate by asking us not to raise questions about the opinion's reasoning. ${ }^{125}$ But how is it that we justify a request to ignore the confused reasoning that is the basis for a rule of reason? Should we ignore the logic to save the conclusion? If so, are we convinced that this conclusion-the rule of reason-somehow constitutes an exception that proves the rule, or have we come upon a contextless and thus absolutely true proposition? Does reason always rule, even if it is a consequence of irrationality? ${ }^{126}$ Perhaps, but the 1955 $A G$ Committee Report offers another possibility-it asks us to reconsider the proposition in light of modern developments. ${ }^{127}$ In short, the conclusion is appended to a new logic, like an old tail pinned on a new donkey.

2. Standard Oil-Modern Developments. Before pinning our hopes on a new logic, we should pause to consider the second inquiry: What modern development sheds new light on the dim Standard Oil opinion and its old rule of reason? It is the economic image of "workable competition." 128 The Committee suggests that the ideals of perfect competition and perfect monopoly are purely analytic tools, and that perfect competition is neither possible nor desirable. Instead, the appropriate antitrust goal is "workable competition" rather than "workable monopoly." 129 The Report summarizes ten factors identifying workable competition; the last, longest, most complex, and least significant is price discrimination. ${ }^{130}$ Although "workable competition" is not easy to categorize, the combination of factors promises a pragmatic solution to a difficult problem by offering a workable set of elements to judge the competitive character of a market.

Market analysis founded in workable, rather than pure, competition, admits the inevitability of some market power and thus a sufficient condition for discrimination. ${ }^{131}$ What is surprising is the refusal of the

124. It is ironic that reason as the ruler, the sovereign standard, is imposed on the force of its own statement-despite the standard institutional logic of stare decisis, which calls for the per se rule.

125. 1955 AG COMMITTEE REPORT, supra note 22 , at 5-6.

126. See supra notes $84-92$ and accompanying text.

127. 1955 AG COMMITTEE REPORT, supra note 22, at 5-6.

128. Id. at 320-39. See also Stocking, The Rule of Reason, Workable Competition and Monopoly, 64 YALE L.J. 1107 (1955); P. AREedA, supra note 4, at 40. See generally Clark, Toward a Concept of Workable Competition, 30 AM. ECON. REV. 241 (1940) (suggesting that moderate quality differentials will yield more workable competition than will attempts to conform to the ideal of perfect competition). The model is also called effective competition.

129. 1955 AG COMMITTEE REPORT, supra note 22, at 334-36.

130. Id. at 324-36 (chapter entitled "Economic Indicia of Competition and Monopoly").

131. Id. at 333. Price discrimination is apparently the most indeterminate and thus least significant indicator of workable competition. Id. at 328-32, 333-36. 
Committee to include the Robinson-Patman Act's sensible cost/price logic in its pragmatic market analysis. Rather than critique and reformulate the Act's interpretation as it does Sherman and Clayton Act doctrine, the Committee chooses to exclude it entirely from proper legal analysis of price discrimination. On the other hand, it is not surprising that a committee of lawyers and economists could agree that modern economic developments could revive old doctrine: "With [the Sherman Act's] Rule of Reason to translate into law each advance in economic teaching, the Act has kept abreast of the times." 132 The rule of reason is renewed in the rule of economics. Yet neither form supersedes the other, for each seems to mimic the other's pragmatic style of "rough and ready judgment."133 It is this merger of mirrored logics that forges the 1955 AG Committee's brand of enlightened antitrust argument. ${ }^{134}$

3. An Old Perspective Restored. The third and final question asks what perspective these cognates of law and economics restore. They legitimate the primacy of the Sherman Act and reassert the centrality of the rule of reason. That position has been difficult to justify since Standard Oil, not only because of the criticisms already presented, ${ }^{135}$ but also because the 1914 Congress enacted both the Clayton and Federal Trade Commission Acts to repair the damage to antitrust enforcement perceived in the rule of reason. ${ }^{136}$ Moreover, the Robinson-Patman Act was passed in 1936 to strengthen and to expand section two of the Clayton Act. Each new piece of legislation appears as a supplement, a change in the statutory status quo.

The 1955 AG Committee Report asserts that subsequent developments from extralegislative sources should supplement doctrinal construction to allow statutory reinterpretation. The modern economic idea of workable competition offers a legitimate framework for reconstructing the Sherman Act. Indeed, such notions are nothing new. But how does a new theory justify giving a privileged position to an old statute and an old rule? In other words, does it make sense to apply one chronological

\footnotetext{
132. Id. at 132 .
}

133. Id. at 339 .

134. See generally Bok, Section 7 of the Clayton Act and the Merging of Law and Economics, 74 HARV. L. REV. 226 (1960).

135. See supra notes $118-26$ and accompanying text.

136. For reviews of the legislative histories, see, for example, THE RPA, supra note 10, at 23 ("A principal purpose of both statutes was to suppress specific anticompetitive practices of the kind that Standard Oil and other trusts were alleged to have engaged in but the illegality of which had been left unclear by the Standard Oil decision."); 1 ABA SEC. ANTITRUST L., supra note 16, at 7 ("[T] Sherman Act, interpreted in the light of the 'rule of reason,' was not as effective as Congress had hoped in preventing the amalgamation of independent and diverse competitors into monolithic combines."). 
ordering principle-newer is better-to extralegislative sources in order - to justify application of its converse-newer is worse-to legislative developments? Because it is generally accepted that the most recent statute contains the latest statement of congressional purpose, ${ }^{137}$ then the Robinson-Patman Act ought to take precedence over the Sherman Act. ${ }^{138}$

Certainly statutes are always open to statutory reinterpretation as long as the chronological canon of interpretation is observed. Its observance can even call for a restrained reading of the more recent enactment with an eye toward preserving the earlier one's basic purport. But such pragmatic positions are not taken. Rather, the Committee uses a modern economic theory of workable competition to establish the primacy of the earlier enactment. It then reinforces its economic argument for the Sherman Act's priority by citing Automatic Canteen. ${ }^{139}$ In sum, the 1955 AG Committee seeks to justify its own position by claiming that both doctrinal history and economic reason favor the Sherman Act's new image of workable competition. An apparently irrational Act and its concern with price discrimination simply must defer to a new rule of reason. The Committee's initial consensus regarding "our faith in competition as a form of economic organization" reflects a particular competitive vision shared, perhaps, by the Supreme Court but not by Congress. ${ }^{140}$

The Committee's participation in Automatic Canteen's doctrinal and political economic blockade of the Act is not unanimous. There are several strong dissents. Professor Louis B. Schwartz articulates two clear disagreements with the erasure of the Robinson-Patman Act. First, he criticizes the Committee majority's shift from the Clayton Act's "incipiency" standard to a Sherman Act section two "monopolization"141 stan-

137. See, e.g., lA C. SANDS, SutherLand Statutory Construction $\$ 22.34$ (1972) ("If the new provisions and the reenacted or unchanged portions of the original section cannot be harmonized, the new provisions should prevail as the latest declaration of legislative will.").

138. We could assume that the earliest statute describes an original congressional concern which all others seek to perfect, but neither the Court nor the Committee takes that position. The two statutes are seen as irreconcilable.

139. See 1955 AG COMM1TtEe REPORT, supra note 22, at 164; see also supra notes 114-17 and accompanying text.

140. See 1955 AG COMMitTEe REPORT, supra note 22, at 1. The Supreme Court's doctrinal structure and even the 10 factors of workable competition can support alternative competitive visions. For example, a significantly different image of competition can emerge from emphasizing the first factor's commitment to maintaining a large number of comparably-sized industrial rivals. Id. at 325. For statements of commitment to such multiplicity, see, for example, United States v. Pabst Brewing Co., 384 U.S. 546 (1966); United States v. Von's Grocery Co., 384 U.S. 270 (1966). Monopoly would be illegal per se. Still another form can evolve from the tenth factor-the scope given to the doctrine of price discrimination. The Robinson-Patman Act could be the standard with which Sherman Act doctrine would be reconciled.

141. The standard also includes dangerous probability of monopolization, that is, an attempt to monopolize. See, e.g., Swift \& Co. v. United States, 196 U.S. 375, 396 (1905). 
dard of antitrust injury, since it undermines the Clayton Act's, and thus the Robinson-Patman Act's, concern for "substantial lessening of competition." ${ }^{142}$ Schwartz argues that a Clayton Act injury to competition occurs long before a successful or an attempted monopolization. ${ }^{143}$ Second, he criticizes the majority's inclusion of a Sherman Act section one element of conspiracy to prove price discrimination under the RobinsonPatman Act. ${ }^{144}$ In both instances, it is the Committee's imposition of Sherman Act doctrine, its refusal to deal with congressional policy produced in the Clayton Act and in its amendment, that prompts the dissent.

Other committee members also disagree with the majority's use of the rule of reason to restrain both legislative production and traditional canons of statutory interpretation. One striking dissent invokes the legal realist critique of abstractions like "the logic of the antitrust laws" to dispute the majority's premise that the two statutes are irreconcilable. ${ }^{145}$ That is, if Holmes is correct that the life of the law is experience and not logic, then irreconcilability is an illusory concern. Instead of using the Sherman Act as a standard, we must turn for guidance to "the prevalent moral and political theories." 146 Although traditional democratic theory may identify Congress as the only legitimate arbiter of these theories, ${ }^{147}$ the 1955 AG Committee believes that others, including commentators and critics, have a legitimate claim to authority under the banner of a new rule of reason. ${ }^{148}$ But to warrant that claim, this dissent suggests, the model of workable competition must pass muster as a felt neccessity of the time and as a prevalent moral and political theory, not as simply the product of logic. ${ }^{149}$ The subjugation of the Robinson-Patman Act to the Sherman Act would then appear as a value-driven restraint, not a consequence of modern knowledge, as an exercise of political argument,

142. 1955 AG COMMITTEE REPORT, supra note 22, at 166-67. See 15 U.S.C. $\$ 13$ (a) (1982) (proscribing price discrimination where the effect "may be substantially to lessen competition or tend to create a monopoly").

143. 1955 AG COMMITTEe ReporT, supra note 22, at 220-21 (dissent of L. Schwartz).

144. Id. (dissent of L. Schwartz).

145. Id. (dissent of G. Montagne).

146. Id. (quoting Holmes).

147. See, e.g., A. Bickel, The Least Dangerous Branch 152 (1962) (when courts find a statute unduly vague, they withhold adjudication of the substantive issue in order to set in motion the process of legislative decision).

148. See supra notes $130-38$ and accompanying text.

149. 1955 AG COMMITTEE REPORT, supra note 22, at 220. For recent articulations of such sentiments, see, for example, Horwitz, supra note 82, at 908-12; Markovits, Legal Analysis and the Economic Analysis of Allocative Efficiency, 8 HoFsTRA L. REV. 811, 873-92 (1980). 
not a reason-founded inference. ${ }^{150}$ The 1955 AG Committee's restored .rule of reason, its merger of law and economics, would then be seen as the consequence of political power, of one logic's rhetorical triumph over its rivals. So imagined, the sovereignty of reason is as much a product as it is a process-the rule of reason determines nothing. Instead, it succeeds and rationalizes a political domain already monopolized.

\section{The Strain of IrRationality: A CONCERTED REFUSAL TO DEAL}

The foregoing analysis uncovers some strains in the analytic textures of two attempts to make sense of the Robinson-Patman Act and to plot its proper place within the antitrust laws. Edwards seeks to rescue a political product from its darkly undisciplined origins by the light of reasoned, economic elaboration of its possibilities. The 1955 AG Committee reports that the Act must yield to a reconstituted rule of reason whose substantial rationality is the economic notion of workable competition and whose doctrinal consequence is the primacy of the Sherman Act. Both are attempts to rationalize the price discrimination statute. Moreover, their concerns and their methodologies encompass not only economic but also traditional legal principles. Finally, both Edwards and the 1955 AG Committee portray their enterprises as choices among differing images of interacting institutions-economic markets, governmental offices, and legal doctrine-and thus choices among alternative discourses with differing logics.

Another more militant group of texts has appeared to present a different argument against the Robinson-Patman Act-a strain of irrationality. No longer do political differences somehow produce a logic; neither do interacting views of social policy and legal doctrine produce a workable rule of reason. Rather, antitrust legal doctrine in general and the price discrimination statute in particular are described as irrational, mad, even dangerously diseased. These texts argue that we must choose, not between two normative themes or two political paradigms of the proper bridge between an idea of the market and an idea of the polity, but instead between logic and illogic, reason and madness, health and sickness. In short, we must choose economics if we are to choose logic, reason, and health.

This claim of economics' monopolization of antitrust rationality is the subject of a well-known dialogue which began some twenty years ago

150. Compare R. Unger, KNowledge and Polmics (1975) with M. Foucault, Power/ KNowledge, supra note 4 and J. HABERmas, Toward a Rational SocietY, supra note 9 (differing formulations of the relationships among reason, argument, and belief). 
in the pages of Fortune magazine ${ }^{151}$ and overflowed into the Columbia Law Review. ${ }^{152}$ On one side, Columbia's Harlan Blake and William Jones argue for a traditional three-dimensional antitrust rule of reason, contending that, in addition to economic efficiencies, the political objectives of self-policing markets ${ }^{153}$ and of protecting individual freedom and opportunity ${ }^{154}$ are also significant antitrust objectives. On the other side, Yale's Ward Bowman and Robert Bork contend that an antitrust rule of reason must be one-dimensional and purely efficiency-based. ${ }^{155}$ But when Bork and Bowman's kindred price theorists turn their attentions to the Robinson-Patman Act, less sanguine forms of argument ${ }^{156}$ often displace such scholarly debate.

As early as 1952, Edivard Levi observed that "the literature on the Act has become something of a contest of witticisms."157 Levi also commented that "the more vulnerable position of the Robinson-Patman Act makes it take punishment intended for the Sherman and Clayton Acts . . . . [T]here is poetic justice in this, because the Robinson-Patman Act tends to be a price-fixing statute hiding in the clothes of anti-monopoly and pro-competition symbols."158

Levi asserts that such criticism has uncovered-perhaps unwittingly - a substantial anticompetition basis for concern. He argues that the Robinson-Patman Act-a sheep in wolf's clothing-really represents a deep distrust of competition and calls for an eeonomy of managed prices. ${ }^{159}$ But Levi's description of an antitrust masquerade is itself a cover. It serves only to suppress competition's ideological dilemma and

151. Bork \& Bowman, The Crisis in Antitrust, ForTUNE, December 1963, at 138.

152. See The Goals of Antitrust: A Dialogue on Policy, 65 Colum. L. Rev. 363 (1965) (five-part symposium, consisting of a critique of antitrust policy by Professors Bork and Bowman, a defense of antitrust policy by Professors Blake and Jones, and rebuttals of each).

153. See Blake \& Jones, Toward a Three-Dimensional Antitrust Policy, 65 Colum. L. Rev. 422, 426 (1965) (any decision to subordinate the political objective of self-policing markets to eeonomic efficiency must be made by Congress).

154. Id. at 430 .

155. See Bork \& Bowman, The Crisis in Antitrust, 65 CoLum. L. REv. 363, 374-75 (1965) (the creation of efficiencies is the main benefit competition offers society, and efficiency is inhibited when antitrust laws protect the competitors from competition).

156. See, e.g., Murray, Injury to Competition under the Robinson-Patman Act: Futility Revisited, 29 U. PITT. L. REv. 623, $625 \mathrm{n} .13$ (1968) ("One of the curious aspects of antitrust scholarship is the emotional tone surrounding discussions of the Robinson-Patman Act.").

157. Levi, The Robinson-Patman Act-Is It in the Public Interest?, 1 ABA SEc. ANTITRUST L. 60,60 (1952).

158. Id. at 61 (emphasis added). In short, is the Act a sheep in wolfs clothing? See Serres, The Algebra of Literature: The Wolf's Game, in J. HARAR1, TEXTUAL Strateg1es 260 (1979) (portraying western metaphysics as sets of ordering principles, derived from and serving the discourse of science).

159. See Levi, supra note 157, at 62. And what is the Act's "more vulnerable position"? This reference points either to the statute's not entirely convincing masquerade or to its perceived flaws of 
to cloak its conceptual incoherence. Rather than recognize the Sherman and Robinson-Patman Acts as problematic statements of both belief and doubt, Levi denies the dilemma by dividing its elements into two simplistic images, two diametrically opposed symbols. In short, he attributes all trust to the Sherman Act and all distrust to the Robinson-Patman Act. ${ }^{160}$ This dissolution of antitrust ambiguity not only encourages a stronger sense of doctrinal and ideological order, but also suggests a better rationale for Levi's observation that the Act takes punishment intended for the other antitrust statutes. Rather than springing from a general dislike of antitrust enforcement methods, the scholarly punishment perpetuates a symbolic scapegoating from which an ideological purity can emerge.

Levi claims that the retribution is just. He would deny the charge of scapegoating. One clear result of this justice is that competition's ideological dissonance remains masked. Levi prescribes an antinomy-the antitrust laws on the one hand and the Robinson-Patman Act on the other-whose asserted irreconcilability can and must be resolved. Ultimately, Levi's masquerade image offers only an ironic illusion of resolution by suggesting that we uncloak the Robinson-Patman Act to reveal the price-fixing statute in hiding. Rather, Levi's unmasking uncovers only another cover-a symbol. The initial symbolization is ignored. The underlying incoherence remains undisturbed.

Levi's article is but a brief introduction to a genre of antitrust argument whose particular focus is the Robinson-Patman Act and whose tone is affectively charged. This section investigates two works that share Levi's vision of essential difference between Robinson-Patman and Sherman Act beliefs about competition. Both authors agree with Bork and Bowman that antitrust analysis of competition should be founded in a one-dimensional rule of microeconomic reason. Moreover, both present antitrust argument that resembles Levi's hyperbole. While Frederick

legislative draftsmanship. See, e.g., C. Austin, Price Discrimination iv (rev. ed. 1953) ("The Robinson-Patman Act is an ineptly drawn statute.").

The argument of symbolic misrepresentation is founded in a claim of essential difference. That is, the metaphor requires that the Act be seen as essentially anticompetitive and that its symbolic clothes be taken as purely and simply pro-competitive. Such reductionism, even if appealing in metaphoric garb, makes little sense. Labeling the Sherman Act as an anti-monopoly symbol ignores the many monopolies it permits (the classic statements of monopolization doctrine's rule of reason analysis can be found in Standard Oil Co. v. United States, 221 U.S. 1 (1911), and United States v. Aluminum Co. of America, 148 F.2d 416 (2d Cir. 1945)); enshrining it as a protector of competition ignores its approval of some price-fixing, see Broadcast Music, Inc. v. Columbia Broadcasting System, Inc., 441 U.S. 1, 20 (1979) (permitting industry-wide price-fixing arrangement because of "unique market conditions"). Indeed, a belief in competition does not preclude distrust of competition. On the contrary, the history of Sherman Act doctrine and policy chronicles a tension that belies such reductionism. Certainly Levi does not mean to deny that complexity. Yet our attitudes about competition tend to be more ambivalent, more questioning, than the Levi metaphor allows.

160. See supra note 159. 
Rowe's Price Discrimination under the Robinson-Patman Act ${ }^{161}$ is still a standard reference book on the Act, Robert Bork's short piece is little known and deliberately unscholarly. ${ }^{162}$ Yet both offer clear opportunities to discover the concerns and strategies surrounding the familiar view of the Act as an anti-antitrust product. Finally, despite their differences in style, form, and purport, they share a striking resemblance at Levi's symbolic level: they characterize the Robinson-Patman Act as a strain of irrationality that poses "a considerable threat to the virtue of the Sherman Act."163

For both Rowe and Bork, the Act is not only the symbolic representation of antitrust irrationality but also the substantial anomaly that causes the doctrinal condition. This section analyzes how these two examples of the LEA forge a structure of the Sherman Act as system and the Robinson-Patman Act as its anomaly to demonstrate the monopolization of price discrimination argument.

\section{A. Rowe's Legal Discrimination as Mere Difference.}

Despite sharing a commitment to rationalize the statute, Rowe sharply disagrees with the Edwards view of discrimination. ${ }^{164}$ Rowe argues that the " 'political idea of discrimination' appears nowhere in the legislative documentation of the Act, and is refuted by the repeated assurances that . . . the 'economic idea' . . . was to be preserved."165 Still, Rowe cannot claim that a purely economic idea characterizes the Act; rather, he accepts the 1955 AG Committee Report's category of legal price discrimination. ${ }^{166}$ Nevertheless, Rowe ignores the Report's adoption of the Automatic Canteen definition of legal price discrimination. Instead, he takes a significantly different legal idea of price discrimination from his misreading of a more recent Supreme Court opinion-FTC v. Anheuser-Busch, Inc. ${ }^{167}$ Rowe's misreading of the case-still accepted by LEA adherents-marks the difference between the two earlier enter-

161. F. Rowe, Price Discrimination Under the Robinson-Patman Act (1962 \& Supp. 1964).

162. Bork, The Place of Antitrust Among National Goals, in BASIC ANTITRUST QUESTIONS IN the Middle Sixties, FifTh Conference on the IMPACt of ANTITRUST on Economic Growth 12 (Nat'1 Indus. Conf. Bd. 1966). 18.

163. Levi, supra note 157 , at 62 . See F. Rowe, supra note 161 , at 23 ; Bork, supra note 162 , at

164. F. Rowe, supra note 161, at 24 n.3 (discussing C. EDWARDs, supra note 21, at 2-13).

165. Id.

166. By "legal price discrimination" or "legal discrimination," I mean the legal doctrine of price discrimination.

167. 363 U.S. $536(1960)$. 
prises and this one, between the strains of rationality and irrationality. ${ }^{168}$ This initial investigation of the LEA strain of irrationality first examines Rowe's denial of Edwards' thesis of political discrimination, then his introduction and dismissal of "mere" legal discrimination, and finally the prevailing logic of economic discrimination.

1. The Denial of Political Discrimination. Rowe argues that legislative history does not support Edwards' thesis that the 1936 Congress considered a political idea of discrimination in its Robinson-Patman Act deliberations. ${ }^{169}$ Although Rowe finds the legislative record replete with references to economic factors, ${ }^{170}$ he asserts that "the analytic economic framework of 'workable' or 'imperfect competition' was not available to illuminate the legislative consideration of the Act." 171 Thus, the record's economic references should not be (mis)taken for 1960 conceptions of efficiency and imperfect competition. Yet Rowe ignores his own caveat: His insistence upon Congress' exclusively economic intent is the first step in the argument that the Act should be construed according to a 1960 form of the LEA. Like the 1955 AG Committee's transformation of the rule of reason, this reconstitution starts with a radical rereading of history and then denies the methodological constraints of history. In short, the argument asks us first to reconsider legislative history, then to ignore it.

Rowe describes the statute as at best a "masterpiece of obscurity"172 and at worst an "historic hoax." 173 He offers studies, showing that economic concentration has remained at or below 1929 levels ${ }^{174}$ in order to refute the "view of the chain-store menace feared at the time of the Robinson-Patman enactment." 175 Rowe asserts that, because the men-

168. First, like Edwards and the 1955 AG Committee, Rowe espouses economic analysis as the appropriate framework for resolving undesirable Robinson-Patman Act doctrine. See, e.g., F. Rowe, supra note 161, at 113-207. Moreover, Rowe repeats his predecessors' distrust of two institutions maligned as political-the FTC and Congress. Id. at 552-55. He asserts that the Commission wants only "scalps," and is "mesmerized by litigation statistics." Id. at 548. Congress, in turn, functions in turmoil and amidst subterfuge. See id. at 551-55 (describing the Act's taking a permanent place in American business life through the offices of its congressional exponents). Rowe's work, however, does differ dramatically in several significant respects. See infra notes 199-209 and accompanying text.

169. F. Rowe, supra note 161 , at 24 n.3.

170. See id. at 24-25.

171. Id. at 24. Although Clark, Toward a Concept of Workable Competition, 30 AM. ECoN. REV. 241 (1940), had not yet been written, J. RoBinson, THE ECONOMics OF IMPERFECT COMPETITION (1933) was certainly available.

172. F. Rowe, supra note 161 , at 19.

173. Id. at 553 .

174. Id.

175. Id. For example, in the retail grocery field, chains accounted for approximately $38 \%$ of the business in both 1929 and 1958. Id. at n.78. 
ace was a figment of the small business lobby's imagination, the enactment of the Act was an historic hoax. ${ }^{176}$ But Rowe's analysis is fatally flawed; the constancy of percentages can also reflect the enormous success of legislation aimed at stopping a succession of chain-store firms. Without more, however, neither interpretation of such figures is warranted. Rowe's stronger argument here dissolves in sloppy analysis.

Its weaker argument declares that the final compromise bill is "a masterpiece of obscurity"177 accomplished by "the technique of amending . . . rather than enacting a separate law . . . a political masterstroke which invested an anti-chain store measure with the venerable trappings of antitrust." 178 This claim is founded in a temporal distinction-in other words, the 1890 Congress apparently enacted respectable legislation, but its later counterpart did not. Some inferences can be drawn from this distinction. First, in contrast to Edwards' parable of two strong zealot factions struggling to a semblance of rationality, Rowe depicts a one-sided victory for "small business lobbies" over powerless consumers. ${ }^{179}$ His description of politics as irrational and unrepresentative denies not only the historical presence and ideological power of Jeffersonian entrepreneurialism, but also overlooks a significant third actor in this drama-big business interests. ${ }^{180}$ In addition, Rowe's portrayal of one interest group as the sole impetus behind the statute raises the question of whether he envisions such political power as momentary. $\mathrm{He}$ seems to suggest that this political scene is always controlled by the strength of one radical group: Rowe argues that amendment is unlikely, not only because the statute will "retain substantial 'small business' and radical support which other supporters of antitrust may feel must be humored in the interests of general policy," 181 but also because self-interested irrationality can be expected to flourish within the institution of Congress. ${ }^{182}$

In short, Rowe warns that we must learn to live with radical irrationality and to humor such madness, for we cannot cure it. Without

176. Id. at 553 .

177. Id. at 19.

178. Id. at 23 .

179. Id. at 554 .

180. Both monopoly and competition were blamed for the Great Depression. The National Industrial Recovery Act, Pub. L. No. 73-67, 48 Stat. 195 (1933), depicted as radical and collectivist, was pluralistically motivated and loosely drafted to allow for flexibility. See E. HAwLEY, THE NEw DeAl and the Problem OF MONopoly 31-46 (1966). However, it did suspend the antitrust laws and form the National Recovery Administration to administer prices. See, e.g., F. RowE, supra note 161 , at 10.

181. F. Rowe, supra note 161 , at 552 n.6, quoting A. NEALE, The ANTITRUST LAWS OF the USA 468 (1960).

182. F. RowE, supra note 161 , at 554 \& n. 81 . 
Edwards' countervailing contestants, ${ }^{183}$ how can the necessary task of rationalization be accomplished, and a reasonable doctrine of price discrimination emerge? Apparently, the category of politics must be rejected-institutionalized-in order to resolve this "paradox of antitrust at war with itself." 184 But will anyone enforce the commitment?

Rowe finds reason for hope; he suggests that the Robinson-Patman Act-this "relic of the Great Depression"185_can be reformed by a reasonable judiciary. Rowe asserts that the federal courts, "[r]ising above the turmoil and the pressures . . . [are] ideally constituted to effect the more enduring values of a rational antitrust policy." 186 Congress reacted passionately and irrationally to the Depression; now the courts must discipline one of the results of that irrationality ${ }^{187}$-the Robinson-Patman Act. Fortunately, Rowe finds, the Supreme Court in Automatic Canteen $^{188}$ has proclaimed an intent to reconcile the Act with "broader antitrust policies."189 Rowe's strategy for deradicalizing the concept of discrimination depends on that intent. First, the madness of politics must be institutionalized, contained to Congress. Next, discrimination, no longer political but not yet economic, must be reformed and assume the name of legal price discrimination. Rowe's strategy generates two significant changes. First, the judiciary's institutional boundaries are substituted for the legislature's and legal displaces political. Second, the inquiry into rationality narrows to one particular disciplinary formprice discrimination. So it is that a doctrine of legal price discrimination is nominated to replace an incorrigible idea of political discrimination. ${ }^{190}$

2. Mere Legal Price Discrimination. Despite the apparently simple solution of legalization, Rowe later characterizes the problem of depoliticizing discrimination as much more complex, declaring that the Robinson-Patman Act was "the offspring of a mixed marriage between antitrust and NRA [National Recovery Administration], born with a

183. See supra notes $89-92$ and accompanying text.

184. F. Rowe, supra note 161, at xi. Rowe's image seems to have impressed Robert Bork, who took the phrase to subtitle The Antitrust Paradox: A Policy at War With Itself, supra note 1. Originally Rowe's description of the Robinson-Patman Act, the phrase represents for Bork the dilemma of antitrust policy.

185. F. Rowe, supra note 161, at 555.

186. $I d$.

187. Id. at 555 .

188. 346 U.S. 61 (1953); see F. RowE, supra note 161, at xii.

189. 346 U.S. 61, 74 (1953); see F. RowE, supra note 161, at xii \& n.12.

190. Yet the "political impulse" cannot be entirely denied; thus it is rendered marginal. See F. Rowe, supra note 161, at $22 \mathrm{n} .89$ (quoting C. EDWARDS, supra note 21, at 12 (arguing that the impulse underlying the law was a political one: to assure the survival of small business)). 
legal split personality."191 Rowe's mixed metaphor presents two related claims about the statute's political origins. First, he sees it as schizophrenic ${ }^{192}$ - as the legacy of a mixed marriage. But once we give up the myth of politics-as-consensus, ${ }^{193}$ then all enactments suffer from some form of conjunctive mania. All statutes are born of interest mixtures. ${ }^{194}$

In addition to the charge of madness, Rowe's metaphor carries implications of illegitimacy. Heredity emerges as the culprit for an unacceptable antitrust-and-regulation mixture. The progeny of the unconstitutional National Industrial Recovery Act ${ }^{195}$ (NIRA) cannot be entirely constitutional-or legitimate. ${ }^{196}$ For Rowe, the price discrimination statute's purported lineage to the NIRA condemns it at the outset. Its madness is attributed to its ancestry.

Rowe points out that the Court has expressed confusion when confronted with the legal split personality of the offspring. ${ }^{197}$ Justice Jackson once remarked: "We have vacillated and oscillated between N.R.A. theory, roughly, and the Sherman Antitrust Law theory ever since I can remember, and we are still wobbling." 198 To meet this implicit request for assistance, Rowe encourages courts to look to commentators for guidance. ${ }^{199}$

191. F. Rowe, supra note 161 , at 23.

192. My use of the word "schizophrenic" derives not from the classical symptomology associated with traditional psychology and psychiatry, but rather from the more recent and rightfully influential notion of the "divided self," developed in the work of R. D. Laing. See R. D. LAING, THE Divided SElF 19-21 (1960); see also G. Deleuze \& F. GuATTARi, ANTI-Oedipus 273-382 (1977) (Laingian schizophrenia presented in sociopolitical context of capitalism).

193. The impossibility of politics-as-consensus is usually traced back to Hobbes. See T. HoBbEs, LEviathan (orig. ed. 1651). The most familiar rendering of a myth of politics-as-consensus is Locke's social contract. See Locke, Second Treatise: An Essay Concerning the True Original, Extent and End of Civil Government, in J. Locke, Two Treatises on Civil Government (orig. ed. 1690); E. PATTERSON, JURisprudence 359 (1953) (argues that Locke's formulation is self-consciously fictitious). For an illuminating critique of the modern version of that myth, see Tushnet, Following the Rules Laid Down: A Critique of Interpretivism and Neutral Principles, 96 HAlv. L. REV. 781, 783-85, 804-24 (1983).

194. The intercourse of difference need not produce madness, whether the transaction is conjugal or political.

195. See Schechter Poultry Corp. v. United States, 295 U.S. 495, 551 (1935) (holding that the National Recovery Act provided for an unconstitutional delegation of congressional authority and impermissibly attempted to regulate intrastate transactions that only indirectly affected interstate commerce).

196. See F. RowE, supra note 161, at 11 (describing the Robinson-Patman Act as the climax of organized efforts begun by business groups anticipating the collapse of the NRA and disappointed by their lack of success).

197. Id. at ix. See FTC v. Ruberoid, 343 U.S. 470,483 (1952) (Jackson, J., dissenting) (price discrimination law is "complicated and vague in itself and even more so in its context. Indeed, the Court of Appeals seems to have thought it almost beyond understanding.") (emphasis added).

198. Tianscript of Oral Argument, Oct. 9, 1950, at 49, Standard Oil v. FTC, 340 U.S. 231 (1951)

(cited in F. Rowe, supra note 161 , at ix).

199. See F. Rowe, supra note 161 , at xiii. 
Taking cues from the Edwards and the 1955 AG Committee prog- noses, Rowe couches his response to the judiciary's question in therapeutic terms. In effect, he recommends analysis. The legal definition of price discrimination must submit to the reason of economics. ${ }^{200}$ Yet Rowe's reading of Anheuser-Busch ${ }^{201}$ marks a significant shift in perspective. While the 1955 AG Committee Report views the Robinson-Patman Act as one of the antitrust laws and thus amenable to proper legal analysis under the rule of reason, Rowe reads Anheuser-Busch as standing for the proposition that the legal definition of price discrimination under the Act "is merely a price difference."202 In other words, Rowe's portrayal of the holding as unmindful of the significance of cost differences suggests that the legal doctrine, and by implication the statute, represents a simple-minded concern. This claim demonstrates the distinction between Rowe's irrational strain of analysis and the earlier one. In particular, while Edwards declares that such simplistic inquiries into inequality are political and thus inadequate, Rowe equates such inadequacy with irrationality and madness. The 1955 AG Committee prescribes the rule of reason as legal treatment of irrationality; here, Rowe, by defining legal price discrimination in terms of mere difference, asserts that legal reason has failed. Rowe concludes that the legal doctrine cannot escape its congenital defect-the irrationality inherited from political discrimination. It cannot overcome its schizophrenia. Confident of such therapeutic failure, Rowe recommends analysis in the form of the logic of economics. Edwards portrays this logic as neutral, as enjoying a classical inheritance that distinguishes it from the dark origins of political discrimination. ${ }^{203}$ Now Rowe counterposes reason and madness: ${ }^{204}$ reason is free to function only while madness remains an institutionalized problem confined to Congress. The courts must recognize that rational price discrimination doctrine requires a diagnosis of politics as madness and an exercise of economics as reason. Only then will price discrimination doctrine escape its legacy of madness, its strain of irrationality.

A closer reading of Anheuser-Busch suggests not only that Rowe ignored the practical context of the statement that legal price discrimina-

200. See id. at 29-31 (arguing that the legal definition of price discrimination as price difference actually compels discrimination in an economic sense under certain circumstances).

201. 363 U.S. 536 (1960).

202. Id. at 549 (emphasis added). See F. Rowe, supra note 161, at 29 (referring to Anheuser$B$ usch's equation of price discrimination with price difference under the Robinson-Patman Act as the "authoritative" legal interpretation). For a similar reading of Anheuser-Busch, see, for example, P. AREEDA, supra note 4, at 1054.

203. See supra notes $30-52$ and accompanying text.

204. See generally M. FouCAult, MADNESS AND Civilization, supra note 2. 
tion is merely a price difference, but also that he forgot that the Court is construing a "procedural text" 205 for an administrative or judicial setting. To establish that a price differential is actually price discrimination, the burden of proof shifts from the plaintiff to the defendant. Plaintiff's evidence of a price difference, its prima facie case, does not close the inquiry, but in practice only opens it. Evidence of cost-justification, meeting competition, and other defenses, as well as evidence in rebuttal, is considered along with the proof of price difference to reach the ultimate issue of undue discrimination. ${ }^{206}$ Despite extensive citation to the 1955 AG Committee Report, and despite his experience as a practicing attorney, Rowe ignores the Act's institutional context. ${ }^{207}$ Moreover, antitrust commentators still cite the case as standing for this undue reading of the statute. ${ }^{208}$ Current legal scholarship's perpetuation of this misreading signifies its agreement with Rowe's view of legal and economic analysis-at least as each applies to price discrimination. Those who believe that economic analysis generates absolute truth refuse to acknowledge the possibility of a logic in legal discourse. Rather, they diagnose its differences from economics' disciplinary forms as irrational. Rowe's view of Anheuser-Busch trivializes the legal doctrine by decontextualizing it. In essence, Rowe poses a leading question: Legal doctrine's reduction of price discrimination to mere difference is the product of madness, isn't

205. 1955 AG COMMITTEE REPORT, supra note 22, at 163 (quoting Automatic Canteen Co. v. FTC, 346 U.S. 61, 75-79 \& n.43 (1953) (distinguishing the procedural portion of section 2(b) of the Clayton Act, which addresses application of rules of evidence under the provision, from the provision itself)).

206. See FTC v. Anheuser-Busch, Inc., 363 U.S. 536, 553 (1960) ("What we have said makes it . . . evident . . . that our decision does not raise the specter of a flat prohibition of price differentials ... . In fact, . . . respondent has . . . contested this very case on the entirely separate grounds of insufficient injury to competition and good faith lowering to meet competition.").

207. Moreover, this legal allocation of proof makes traditional sense. Defendant's burden is appropriate: The elements in the category of affirmative defenses should remain there because the information needed to prove them is peculiarly within the knowledge and control of defendant.

208. See, e.g., infra note 328 and accompanying text (Posner's analysis).

Subsequent court opinions treat the case quite differently than does Rowe. For example, Utah Pie Co. v. Continental Baking Co., 386 U.S. 685, 696 n.12 (1967), eites it as authority for the doctrine that a price reduction below cost tends to establish predatory intent. Even $O$. Hommel v. Ferro Corp., 659 F.2d 340, 346 (3d Cir. 1981), which adopts a Law and Economics Approaeh and sidesteps Utah Pie, cites Anheuser-Busch for the proposition that price discrimination is not illegal per se. See, e.g., Bowman, Restraint of Trade by the Supreme Court: The Utah Pie Case, 77 YALE L.J. 70 (1965) (arguing that Utah Pie restrains competition). If price discrimination were merely a price difference, it would be illegal per se. That is, in a full trial on the merits nothing more than a showing of price difference would be necessary on the issue of price discrimination. See genterally Fulda, The Per Se Provisions of the Robinson-Patman Act, 49 TEx. L. REV. 961, 962-63, 972 (1971) (discussing how the relative ease with which plaintiffs ean prevail under the per se provisions of the Robinson-Patman Act, § 2(c)-(e), 15 U.S.C. § 13(c)-(e) (1982), has led to a flood of suits initiated under those sections). In a private suit for damages, evidence relevant to the issues of causation, injury, and damages would of course be required. 
it? The response is affirmative: Yes, legal doctrine is schizophrenic. The upshot of these two shifts in the idea of discrimination-first a depoliticizing and then a decontextualizing-is the relegation of first political and then legal ideas of discrimination to the category of irrationality. By a process of exclusion-something resembling a boycott-only the economic idea of discrimination remains in the category of rationality. Unrivaled, the economic idea can dominate the relevant market for rational antitrust argument. It can exact its monopoly price for supplying the argument demanded by those who produce price discrimination doctrine.

3. The Logic of Economic Discrimination. What product does the LEA offer that appears so attractive? It is the economic idea of price discrimination. Does it make better sense than its rivals? Or is its position of dominance secured merely in its success at convincing us to engage in a boycott? If so, what is it that convinces us? Rowe's answers, still attractive today, flow from argument about the economic idea of price discrimination, from argument founded on two basic propositions. First, cost/price relations-or "profit differentials"209_describe the proper view of discrimination. ${ }^{210}$ Second, price discrimination is a neutral economic phenomenon. ${ }^{211}$ These two normative statements are essential to the production of an argument that purports to have unrivaled access to reasoned analysis. Moreover, their normative nature is obscured in argument that appears to be analytical. The remainder of this subsection not only explores their analytical frailties but also suggests the ethical ingredients that help make this argument-product so attractive.

a. A cost/price matrix. The first measure of economic rationality is the familiar cost/price analysis prescribed by Edwards and the 1955 AG Committee. ${ }^{212}$ Rowe relies on the latter for his assertion that economic price discrimination occurs whenever price differences are not accounted for by differences in cost. ${ }^{213}$ In order to determine whether there is economic price discrimination, it is necessary to know both the price and the total applicable costs. ${ }^{214}$ The idea is significant in two re-

209. F. Rowe, supra note 161 , at 26 (citing Adelman, Price Discrimination as Treated in the Attorney General's Report, 104 U. PA. L. REV. 222, 223-24 (1955)).

210. F. Rowe, supra note 161 , at $30-31$.

211. Id. at 25. That is, the term "has developed a bad public relations connotation which is not implicit in the economist's use of the word." Id. (citing Backman, An Economist Looks at the Robinson-Patman Act, 17 ABA SeC. ANTITRUST L. 343, 344 (1960)).

212. Id. at 29-34 (citing C. EDWARDS, supra note 21, at 1-5, and 1955 AG COMMitTEE REPORT, supra note 22, at 333-36).

213. Id. at 28 (citing 1955 AG COMMTTTEE REPORT, supra note 22, at 333).

214. Id. 
spects. First, it involves an attractive element of competitive ideology-a competitive market is characterized by a convergence of price and cost. Profits will tend to decrease from monopolistic levels and resources will be allocated optimally. 215 Second, price must be weighed against total costs. ${ }^{216}$ While the statutory defense of cost-justification recognizes only a limited range of costs, ${ }^{217}$ Rowe's economic approach considers any element of cost, tangible or intangible, "whether or not precisely measurable or allocable to a particular product."218 Thus Rowe's economic notion of cost, though theoretically more complete, is imprecise and probably incalculable. As a result, his economic idea of price discrimination-founded in cost/price differences-cannot rationalize the statute in any practicable sense. It seems that we are left with an unrealizable theory that cannot make even a mere difference.

Rowe's analysis amounts to an argument for free markets. This preference for the status quo persists throughout Rowe's first measure of economic rationality. He acknowledges that the cost/price nexus is causal, but argues that price variations are based on the "interplay of manifold economic pressures."219 A pure cost approach, therefore, is irrational, 220 and a statutory or legal doctrine of price discrimination founded in such delusions must be mad. Such "archaic"221 notions are out of touch with both economic logic and commercial reality.

But Rowe twice misinterprets the idea of causation. First, he assumes that price variations are causally based-not on cost, but rather on an interplay of economic pressures. Modern scientific conceptions of relationships among variables tend to avoid the quagmire of causality. Both the physical and the social sciences have adopted probability models of correlation or other quantitative techniques to describe relation-

215. See, e.g., P. AREEDA, supra note 4, at 7-20; Markovits, A Basic Structure for Microeconomic Policy Analysis in Our Worse-Than-Second-Best World: A Proposal and Related Critique of the Chlcago Approach to the Study of Law and Economics, 1975 W1S. L. REV. 950, 1237-43.

216. F. Rowe, supra note 161 , at 30 .

217. Under the Robinson-Patman Act, the cost-justification defense is limited to price differences caused by "differences in the cost of manufacture, sale, or delivery resulting from the differing methods or quantities in which such commodities are to such purchasers sold or delivered" or by "changing conditions affecting the market for or the marketability of the goods concerned." Robinson-Patman Act, § 2(a), 15 U.S.C. § 13(a) (1982).

218. F. Rowe, supra note 161, at 30. Moreover, while the Robinson-Patman Act entertains only historic or actual costs, the economic view "takes into account any cost anticipated or realized by the supplier at any time in relation to a product." Id.

219. Id. at 31 .

220. Id. at 31-32.

221. Id. (quoting Backman, An Economist Looks at the Robinson-Patman Act, 17 A.B.A. SEC. ANTITRUST L. 343, 357 (1960) (terming the cost theory of pricing "antediluvian," "archaic," and "simple")). 
ships among variables. ${ }^{222}$ In the empirical discipline of microeconomics, such quantified formulations have long ago displaced ideas of logical or direct causation. ${ }^{223}$ On the other hand, contemporary price theorists tend to describe price as the independent variable, the model's element of causation rather than an effect. ${ }^{224}$

Second, like his misreading of the Anheuser-Busch doctrine of price discrimination, ${ }^{225}$ Rowe misses the mark because he refuses to acknowledge a logic in legal discourse in order to make a point about economic logic. Notwithstanding Rowe's equation, legal causation is not synonymous with logical or direct causation. Instead, the doctrine of legal causation incorporates value judgments about how foreseeability or fault affect the location of legal responsibility. ${ }^{226}$ The statutory defense of cost-justification for price discrimination certainly need not be based on a system founded in cost as the cause in fact of price. The legal doctrine of price discrimination can be seen as the result of an institutional value judgment-either a desire to emulate the competitive market feature of cost/price convergence or simply a belief that firms ought to price according to costs. Whether or not the logic of such legislative judgments is recognizable in given economic models or legal doctrines, it need not be founded, justified, or analyzed within Rowe's idea of causation. Nonetheless, Rowe suggests that there is no rational approach for assessing the relationship between cost and price.

222. See, e.g., S. J. Gould, THE Mismeasure of MAN 239-56 (1981) (critiquing historical development of intelligence testing); Underwood, Law and the Crystal Ball: Predicting Behavior with Statistical Inference and Individualized Judgment, 88 YALE L.J. 1408 (1979) (discussing underlying assumptions, costs, and benefits of social science techniques in various legal settings); Tribe, Trial by Mathematics: Precision and Ritual in the Legal Process, 84 HARV. L. REv. 1329 (1971) (critiquing use of statistical techniques in litigation).

223. For example, microeconomics pictures elasticities of demand-changes in demand that accompany changes in price-as ratios of percentages, not as causes and effects. See, e.g., R. POSNER \& F. EASTERBROOK, ANTITRUST 624 (1980) [hereinafter cited as POSNER \& EASTERBROOK]; ANTITRUST LAw, supra note 6, at 9-10, 56-57, 125-26, 194-95; P. SAMUELSON, ECONOMICS 362-65, 36869 (7th ed. 1967). Regarding science and uncertainty, see, for example, P. FEYERABEND, AGAINST METHOD (1975) (discussing methodological uncertainty); W. HEISENBERG, PHySiCS AND PHILOSOPHY: THE ReVOlUtion IN MODERN SCIENCE (1958) (discussing empirical uncertainty); M.F. Sciacca, Philosophical TRENDS IN the Contemporary WoRld 62-70, 460-69 (1964) (analyzing epistemological context); N. WeINER, THE HUMAN Use OF HUMAN BeINGS (1954) (describing the state of nature as uncertainty-seeking). For explanations of structural causality, see, for example, F. Jameson, The Political Unconscrous 9-14 (1981) (literary criticism and social theory); F. SCHERER, supra note 13, at 1-9, 151-56 (1980) (economics); M. SERRES, supra note 2, at 16-28.

224. Price theorists also describe price as codependent with output changes. See, e.g., R. BoRK, supra note 1 , at 116-33. In this sense, the price theory model is archaic.

225. See supra notes $201-08$ and accompanying text.

226. See, e.g., L. Green, Rationale of Proximate Cause (1927) (legal realist critique of proximate cause); Edgerton, Legal Cause, 72 U. PA. L. REv. 211 (1924) (analysis of doctrine of legal causation); Horwitz, The Doctrine of Objective Causation, in THE PolrTics of LAW 201 (D. Kairy ed. 1982) (legal historical inquiry into objective causation). 
b. Price discrimination: a neutral phenomenon. If we accept the proposition of unrealizability, then what can we do about the problem of price discrimination? Rowe responds that economic price discrimination, properly envisioned, is a neutral phenomenon. ${ }^{227}$ By implication, we need do nothing. That simple logic purports to rationalize the separations of price from cost, of the Robinson-Patman Act from rationality, and of economic price discrimination from practical applicability. In other words, this argument of neutrality seeks to legitimize the status quo. Rowe attempts to defuse the perceived danger by arguing that economic price discrimination has no normative overtones: It is not entirely bad. It is both good and bad. However, that claim is also grounded in questionable logic about the forms of price discrimination and their relationship within the confines of neutrality. In fact, the concept of neutrality can be viewed in two different ways-static or dynamic. Both forms seem to mimic the very legal schizophrenia to be cured and both ignore more promising treatments.

i. Static indifference. This static idea of neutrality portrays economic price discrimination as always self-offsetting. That is, while it may be a "predatory or preclusive tactic," 228 it can also be a "symptom of effective competition."229 The healthy form of sporadic, nonsystematic discrimination enhances competition and is good. The unwholesome form of stable, systematic discrimination implies monopoly and is bad. However, their net effect is neutral-at every moment there is perfect equilibrium of good and bad. And so we need do nothing. Although this notion of neutrality is not very convincing, what do we make of Rowe's characterization of the antipathy raised by the term discrimination as "a bad public relations connotation," as an obscuring projection of nonneutrality cast upon an essentially neutral core of economic rationality? ${ }^{230}$

ii. Dynamic indifference. A second and more complex image of neutrality requires a dynamic summation process-neutrality over time: Although at particular moments there may be an excess of procompetitive or anticompetitive price discrimination, over the long run it is selfnullifying. In effect, this form of neutrality does not differ from the first, for it appears that both versions-static and dynamic-encourage us to do nothing about price discrimination. Yet Rowe's book is not a twentyfive page article or leaflet that ends on that note. Rather, it continues for

227. F. RowE, supra note 161 , at 25 .

228. Id. at 28.

229. Id. at 25 (footnote omitted).

230. $I d$. 
hundreds of pages and through a later supplement to describe the potential harms of stable, systematic price discrimination. It restates the axiom that "[p]rice discrimination, in the economic sense, occurs whenever ... price differences . . . [are] not accounted for . . . by changes in the level of demand."231 In other words, shifts in buyer preferences cause sporadic, unsystematic price differences. This is the familiar microeconomic model of a competitive market's movements to equilibrium. ${ }^{232}$ On the other hand, a market at equilibrium exhibits no such price differences, unless it is monopolized, and then the pattern is stable and systematic.

This distinction is troublesome. First, because almost all markets under antitrust scrutiny fall outside the ideals of perfect competition or monopoly, ${ }^{233}$ we must usually characterize the form of discrimination without reference to a clear structure of industrial organization. Thus, the economic problem of price discrimination calls for regular and longterm observations in order to distinguish between sporadic and systematic discrimination. But such consideration cannot consist merely of looking at pricing conduct, because recognizing sporadic discrimination presumes static equilibrium as the normal context. Because markets are almost always in flux, the assumption of stasis is untenable. Indeed, the dynamic model of neutrality formalizes the premise of flux. In consequence, markets are envisioned in the constant state of adjusting to demand and other changes. A constant state of purportedly sporadic discrimination looks constant. As a result, the model insists upon a systematic characterization of all discrimination.

c. Analysis without cure. With both structure and pricing patterns as indeterminate indicators, the inquiry has no clear analytic methodology. Still, both economic rationality and competitive ideology demand differentiation between sporadic and systematic forms of economic price discrimination. ${ }^{234}$ In light of the methodological impossibility of differentiation, the significance of Rowe's asserted neutrality emerges: Because failure to enforce the Robinson-Patman Act would simply support neutrality, nothing need be done. In theory, therefore, it is not important that we cannot distinguish forms of price discrimination.

231. Id. at 29 (quoting 1955 AG COMMITTEE REPORT, supra note 22, at 333-34).

232. For clear descriptions of the economic notion of equilibrium, see, for example, P. SAMUELSON, ECONOMics 43-45 (10th ed. 1976); L. Sullivan, supra note 14, at 2-5.

233. See, e.g. P. AREEDA, supra note 4, at 12-17; 1955 AG COMMITTEE REPORT, supra note 22, at $318-20$.

234. See, e.g., F. Rowe, supra note 161, at 28. 
But in practice, it is important to assure that nothing is done. The undisciplined and irrational politics of the Robinson-Patman Act destroys the theoretical neutrality of economic price discrimination. Whether by amendment or reinterpretation, the madness of legal price discrimination must be treated with the prescriptions of rational economic argument.

While both measures of economic rationality discussed-cost/price logic and neutrality-predate the Rowe book, ${ }^{235}$ here they participate in an argument that clearly shows the effects of the strain of irrationality. On the one hand, legal discrimination doctrine is portrayed as accepting the counterfeit logic of mere difference. Rowe describes such false currency as the legacy of an extreme form of irrationality. Thus, the cure for a legal schizophrenia is to break the legal idea's unacceptable lineage to politics. In other words, legal price discrimination has within it an imprisoned rationality-economic price discrimination. Only by institutionalizing the legal idea and constraining its irrationality can the economic idea emerge.

Nonetheless, the attractive logic of economic price discrimination itself appears to contain the frailties of the legal doctrine it purports to rationalize. Its cost-price matrix explicitly denies a practice and thereby lapses into the insignificance of its legal counterpart. Its conjunctive form of neutrality - both good and bad-traces the path of schizophrenia attributed to legal price discrimination. In sum, Rowe exploits a metaphor of madness to characterize legal schizophrenia as the price of pluralism and to prescribe economic analysis as the treatment. Despite its weak condition, such economic analysis retains its position of dominance in the field of rational price discrimination argument.

\section{B. Bork's "Typhoid Mary": A Call for Quarantine.}

Robert Bork's The Place of Antitrust Among National Goals ${ }^{236}$ is the footnote-free text of a speech given at an industrialists' conference on the proper place of antitrust in the economy of the mid-1960's. Thus, both the topic-antitrust policy issues-and the forum-a conference of industrialists-invite informality. This pointed assault on antitrust policy begins and ends with entertaining parables that share a political moral with a decidedly serious purport. It argues that antitrust doctrine and

235. See, e.g., Burns, The Anti-trust Laws and the Regulation of Price Competition, 4 LAw \& CONTEMP. ProB. 301, 301 (1937); Clark, supra note 129. For a recent shift in Rowe's perception of the relationship between law and economics, see Rowe, The Decline of Antitrust and the Delusions of Models: The Faustian Pact of Law and Economics, 72 GEo. L. J. 1511 (1984) (delusive certitude of economic models yiclds false norms and thwarts discourse toward wise policies).

236. Bork, supra note 162 , at 12 . 
policy, as developed, are overextended, incoherent, and socially unredeeming. 237

In general terms, Bork argues that antitrust cannot "be fully worthy of the free-market ideal it purports to serve"238 as long as it is "serving every national goal except the prevention of lascivious carriage."239 It "can only resume its rightful high place among our national goals if we cleanse it of the social purposes doctrine and the transfer-of-power theory which give it its protectionist bias." 240 The first wash would focus the vision of myopic policymakers, while the second would remove the st(r)ain of irrationality from an otherwise clear lens of microeconomic analysis.

This section first investigates Bork's twin call to argument purification by examining the logic and the underlying premises that purport to substantiate his claims that the social purposes doctrine and transfer-ofpower theory should be eliminated from antitrust doctrine. The section then identifies the particular treatment called for and finds a free marketeer's call for protection from the danger of the Clayton Act and the Robinson-Patman Act amendment-a call for quarantine of this " 'Typhoid Mary' of the protectionist disease."241

1. Social Purposes Doctrine. Bork finds two things wrong with the law: "One is the part of it that is not economics; the other is the part that is." 242 The noneconomic part consists of the notion that doctrine should serve social and political purposes other than wealth maximization. ${ }^{243}$ Bork does not contend that such purposes have no place among national goals. They simply do not belong to antitrust, whose designated mission is a narrow one of "keep[ing] markets free so that our nation can be wealthy."244 It is also a neutral mission; how we use that wealth is a question "to be answered in other ways." 245 The social purpose of free markets apparently interacts with other social purposes in a unique antitrust variable-sum game. If we choose free markets first, then that choice does not impinge upon and perhaps serves other purposes-a positivesum game. But if another social or political purpose is given priority,

237. See id. at 12-13, 22. The arguments are repeated in $\mathrm{R}$. BoRK, supra note 1 , at $382-401$.

238. See Bork, supra note 162, at 22.

239. Id. at 12.

240. Id. at 22. A third problem is mentioned in passing: the evolution of the Antitrust Division of the Justice Department into an administrative agency. Id. at 13.

241. Id. at 18 .

242. Id. at 13.

243. Id. Bork's form of wealth maximization, which he also calls consumer welfare, is comprised of allocative and productive efficiencies. See R. BORK, supra note 1, at 90-106.

244. Bork, supra note 162 , at 13.

245. Id. 
then wealth maximization suffers-a zero- or negative-sum game. Within the borders of antitrust argument, wealth maximization should be given priority, because social and political purposes are "subversive of all that antitrust should stand for."246 Once outside antitrust, we can serve the other purposes.

The idea of boundaries between antitrust and other doctrinal statements of national goals is critical to Bork's scenario. He makes two arguments to convince us that such boundaries are desirable-the first founded in an image of neutrality, the second in the notion that both Congress and the federal courts share an original antitrust intent of maximizing wealth. ${ }^{247}$

a. Wealth maximization and political neutrality. Before proceeding to Bork's propriety justification, a brief discussion of the claim of neutrality is necessary. If wealth maximization is not a neutral social or political purpose, then we must be on the lookout for this goal's effects on other values. Recent scholarship has already demonstrated the impossibility of claiming such neutrality. ${ }^{248}$ The claim that consumer welfare is a neutral and thus an uncontroversial social or political purpose can no longer provide the stylus for drawing normative borders around antitrust doctrine. Rather, the choice of any particular social or political purpose is a transaction whose normative and analytical consequences cannot be contained by the categorical boundaries we imagine. If neutrality cannot support the claim that wealth maximization should be the only antitrust goal, then such analytical isolation is no longer possible. At least three alternatives for policy analysis present themselves: (1) antitrust doctrine must take account of those other concerns; (2) we must be convinced not only that consumer welfare is an important social or political purpose but also that it is the most important social purpose; or (3) some nonnormative basis for choosing consumer welfare must be offered.

b. Wealth maximization and congressional intent. Bork's boundary argument relies on a traditional legal form of the third strategy. $\mathrm{He}$ contends that the federal courts and Congress share an original antitrust intent of maximizing wealth. ${ }^{249}$ This claim quickly fails. It begins with the assertion that antitrust statutory language has the "polar models" of "competition" and "monopoly;" such models are "appropriate to eco-

246. Id.

247. Id. at 15-17.

248. See Symposium on Efficiency as a Legal Concern, supra note 19; A Response to the Efficiency Symposium, 8 HOFsTRA L. REV. 811 (1980).

249. Bork, supra note 162 , at 14-15. 
nomic analysis and not to political science or sociology."250 But can we take seriously the proposition that Congress had in mind only or primarily wealth maximization when it outlawed trusts in 1890 ? Certainly legal and social historians agree that the concern for the social and political consequences of great aggregations of capital —of trusts-was clearly and repeatedly articulated not only in the halls of Congress but also in the publications of the day. ${ }^{251}$ There is little question that current microeconomic notions such as allocative efficiency were not even part of the imagination of the times. ${ }^{252}$ Rather, the discourse was political economy and the central interest in competition and monopoly was distributive. ${ }^{253}$ And what do we make of the claim that passage of the 1914 Clayton Act was only, or primarily, motivated by contemporary ideas about Pareto efficiency, ${ }^{254}$ not the well-documented congressional disapproval of Standard Oil ${ }^{255}$ so approvingly cited in the Bork text?256 This claim of such singular or primary Congressional intent is historically, practically, and theoretically unsound. ${ }^{257}$ The only rationale for this claim of a legitimate monopolization of the meaning as well as the proper use of such historically familiar terms as "competition" and "monopoly" is that they are "models appropriate to economic analysis and not to political science or sociology."258

Bork proceeds by criticizing those who refuse to read the antitrust statutes as law and economics texts: "[T] here is surely a strong case for taking Congress at its word and requiring that body, if it wants to protect

250. Id. at 15 .

251. See, e.g., Harris \& Jorde, Market Definition in the Merger Guidelines: Implications for Antitrust Enforcement, 71 CALIF. L. REv. 464, 465-68 (1983) (the antitrust laws were enacted in large part to respond to the concerns of fairness in economic distribution and fairness in the process of exchange, not just economic efficiency).

252. Wilfredo Pareto's Cours D'Economie Politique (1897) (A Course in Political Economy) certainly was not available in 1890 and not in translation until 1936. Thus, the strict economic form of allocative efficiency-Pareto superiority-had not yet developed. For a brief discussion of forms of allocative efficiency, see infra notes 412-59 and accompanying text. Although Jevons' Theory of Political Economy (1871) (marginal utility) had already demonstrated a quantification of Bentham's utilitarian ethic, not even late nineteenth-century American economists, much less legislators, showed interest in demand. Rather, they concerned themselves with supply-side market problems. See, e.g., W. L. LETwIN, supra note 13, at 71-77 (rise of American Economic Association, Henry Carter Adams' tripartite classification of industry based on returns to scale, and the propriety of government intervention). The Sherman Act's passage has been described as a political impulse whose economic underpinnings were, at best, unarticulated. See Hofstadter, What Happened to the Antitrust Movement?, in The Paranoid StYle in AMERICAN Politics and Other Essays 19698,233 (1965).

253. See T. W. Hutchinson, A Review of ECONOMIC Doctrines: 1870-1929 252 (1953).

254. See supra note 252.

255. Standard Oil Co. v. United States, 221 U.S. 1 (1911).

256. See Bork, supra note 162 , at 15.

257. See supra notes $74-82$, infra notes $412-17$, and accompanying text.

258. Bork, supra note 162 , at 15 . 
inefficiency, to face and debate the question directly and phrase its command in words that make the political decision and its costs apparent . . ."259 Certainly if the issue were ever debated, no one in or out of Congress would want to protect inefficiency. But perhaps a different question would yield a different answer. The question whether Congress ever expressed concern about "other social and political purposes" would certainly elicit an affirmative response. Indeed, both the Clayton Act and its Robinson-Patman Act amendment represent clear examples of such concerns.

It is not surprising that Bork decries these statutes as dangerous to the health and virtue of a wealth-maximizing Sherman Act. They inject other harmful social and political purposes into an otherwise proper freemarket antitrust calculus. The problem with the noneconomic part of antitrust law, we are told, is its very existence.

2. Transfer-of-Power Theory. Even if such excision purges antitrust argument of its social and political impurities, recall that Bork demands also that the economic part of antitrust law be cleansed of something called the "transfer-of-power" theory. ${ }^{260}$ For, like its contaminated counterpart, "[i]t, too, imports a protectionist virus into antitrust."261 This demand raises three questions. First of all, how is this theory translated into familiar antitrust doctrine? Next, what does Bork claim is wrong with it? And finally, what's to be done?

a. From theory to doctrine. Initially, Bork associates the "transfer-of-power" theory with the antitrust doctrine of "incipiency." That is, the Clayton Act and the Robinson-Patman Act are concerned with restraints "before they grow to Sherman Act proportions"262 - that is, before that statute's threshold of monopoly power is crossed. "These statutes prohibit certain behavior . . . when their effect 'may be substantially to lessen competition, or to tend to create a monopoly.' The key word is 'may'."263 For example, a merger or price discrimination need not create a monopoly; it need only tend to create one. In particular, Bork describes and then repudiates the theory's purported "premise . . . that it is possible to transfer power from one place to another, and keep it in the first place, too."264 This alludes to the familiar antitrust "leverage" theory. While the speech does not explicitly relate the three no-

259. Id.

260. Id. at 22.

261. Id. at 18.

262. Id.

263. Id.

264. Id. 
tions-incipiency, transfer-of-power, and leverage-it does treat the last two as synonymous terms that describe inadequate economic theory for the antitrust doctrine of incipiency. ${ }^{265}$ As a prelude to tracing Bork's aversion to the incipiency doctrine, this section analyzes the rationales given for finding the leverage or transfer-of-power image to be inadequate economic theory.

b. Two critiques of leverage theory. Bork adopts two forms of argument to convince us that leverage theory makes no sense. One rests on the power of explicit analogy, the other on the appeal of purported economic rationality.

The first argument proposes that leverage theory "resembles a particularly weird form of non-Euclidean geometry that starts from premises that seem contradicted by common sense, and then reasons inexorably to conclusions that have nothing to do with anything on this planet." 266 The premise is the possibility of transferring power from one place to another while keeping it in the first place, which, like a nonEuclidean premise, seems to contradict common sense. But are non-Euclidean premises, even if counterintuitive, inapplicable to the real world? In fact, a number of familiar physical phenomena can best be explained by abandoning one or more of the strict Euclidean postulates. ${ }^{267}$ Despite

265. See id. at 18.

266. Id. See Frank, Mr. Justice Holmes and Non-Euclidean Legal Thinking, 17 CoRNELL L. REV. 568, 572-79 (1932) (non-Euclidean means non-axiomatic).

267. First of all, what might it mean to resemble non-Euclidean geometry? Euclidean geometry is founded in five basic beliefs or postulates and in a syllogistic methodology. See Barker, Geometry, in 3 ENCYCLOPEDIA OF PHILOSOPHY 285, 285 (1967). Until the nineteenth century, mathematicians believed that all true statements about geometry could be deduced from these postulates and a small number of axioms. Critiques of Euclidean geometry and developments of alternatives focused on both its deductive logic and its premises. The most familiar form of non-Euclidean geometry abandons the fifth postulate-a notion that we all take for granted and rely upon-that parallel lines do not meet. See Barker, supra. See also Penrose, The Geometry of the Universe, in Mathematics TODAY 83 (L. Steen ed. 1978) (description of the evolution of Euclidean geometry into differential geometry). It derives alternative systems of geometry that do not allow us to imagine such straight lines. Notwithstanding that counterintuitive demand, the conclusions reached have everything to do with this planet. The simplest example is the familiar set of longitude lines on a globe. Each represents the shortest distance between the North and South Poles to meet the Euclidean definition of straightness; each also passes through a point not on the other lines. Thus, they are all parallel; yet they all meet. The obvious complication is the surface. By imagining a sphere rather than a flat plane, we can make a different common sense. It is easy to see how non-Euclidean premises can quickly eclipse their initial appearance of "weirdness." Nonetheless, Bork laments that the "lawyer is compelled to analyze a Euclidean world with non-Euclidean theorems." Bork, supra note 162, at 21. Bork's vision of a Euclidean world would require us to forget that the world is round. We would also have to forget Einstein, relativity, and most of theoretical physics; for all of these ideas emerge from non-Euclidean counterintuitive geometries. See Penrose, supra, at 83-84. Especially if Bork desires to identify economics with the modern sciences, see $\mathrm{R}$. BORK, supra note 1 , at 8 , and if he purports to appeal to twentieth-century beliefs about what constitutes "the real world," then analog- 
Bork's rhetoric of implausibility, likening transfer-of-power theory to non-Euclidean geometry seems instead to support that theory's implausibility.

But even if there is nothing wrong with such postulates in general, perhaps the particular one at issue makes no sense. The transfer-ofpower theory in a mechanical context is clear enough-the simple lever is a machine that transfers power from a point of exertion to a point of resistance. Depending not only upon the force exerted but also upon the lever length and fulcrum placement, the principle of leverage has come to represent the capability of enhancing the power exerted. None of that appears particularly weird or otherwise unacceptable. And so it must be the principle's descriptive power in the antitrust context that has "nothing to do with anything on this planet." 268

Having drawn the analogical argument to unconvincing conclusions, Bork shifts to a critical strategy founded in an economic logic. In particular, he quickly reviews several Supreme Court opinions to illustrate the inadequacy of the economic theory of leverage. He proclaims that this short-sighted theory requires the Court to err by "double counting of market power."269

The first opinion chosen to represent the inadequacy of leverage theory is a Sherman Act case, United States v. Griffith, ${ }^{270}$ in which the Court held unlawful a motion picture theatre chain's master agreement with individual film distributors to cover its entire circuit of eighty-five towns. ${ }^{271}$ In thirty-two of those towns, there were competing theatres. Film distributors granted to the chain certain exclusive privileges in both monopoly and competitive towns, including pre-emption in film selection and clearances over competing theatres. ${ }^{272}$ The Court found that films were "licensed on a non-competitive basis in what would otherwise be competitive situations."273

ical argument founded in pre-nineteenth-century conceptions of a world uniquely describable in Euclidean terms cannot be counted on to convince anyone. Certainly no one is ready to believe again that the world is flat, even if that image stakes an unrivaled claim to economic rationality. In short, what's wrong with a non-Euclidean premise?

268. Bork, supra note 162 , at 18 .

269. Id. at I9.

270. 334 U.S. 100 (1948). There are two companion cases: Schine Chain Theatres, Inc. v. United States, 334 U.S. 110 (1948) (chain of 148 theatres exercised monopoly power in violation of the Sherman Act), and United States v. Paramount Pictures, Inc., 334 U.S. 131 (1948) (vertical combinations of producing, distributing, and exhibiting motion pictures violated the Sherman Act).

271. 334 U.S. at 109; see Bork, supra note 162, at 19 (discussing Griffith).

272. Griffith, 334 U.S. at 102. That is, the chain had first choice of films in all 85 towns, and the agreement specified the time interval between first-run and later exhibitions.

273. Id. at 108 . 
Bork's discussion focuses on the distributor's purported role in the plan of the chain:

The Court necessarily assumed that the theatre chain could keep its monopoly advantage - a lower price-in its monopoly towns, and simultaneously use the same power to get monopoly advantages in towns where it faced competition. . . . The film distributor may be willing to pay the monopoly price for a town once, but when he is asked to pay for it again by giving extra concessions in competitive towns, he will surely reply that he is not accustomed to buying the same thing twice. The Court's economic theory involves double counting of market power. ${ }^{274}$

How is it that the Court's analysis requires an assumption that individual film distributors paid twice? First, Bork offers the following scenario to describe an unsustainable predicate for transfer-of-power theory: The distributor paid first by receiving only a monopsonist's ${ }^{275}$ price for its films in monopoly towns. It paid again by giving concessions like preemptions and clearances in competitive towns. ${ }^{276}$ In short, Bork's critique of leverage theory asserts that the foregoing vignette properly describes the double counting of one source of market power. It does not.

In order to portray the Griffith opinion as founded in double counting, Bork shifts the focus from excluded competitors to exclusive distributors. In so doing, he can profess concern for firms that enjoyed market domination. He can overlook industry practices indicating that the master agreement benefitted both parties. ${ }^{277}$ These two oversights illustrate the economic irrationality of reading this opinion as necessarily founded in the "old double counting game."278

274. Bork, supra note 162 , at 19.

275. Monopsony describes a market with only one buyer for a good or service.

276. See id. Otherwise, the master agreement would have no economic consequences. The chain can pay for competitive town concessions with monopoly town profits without an agreement.

277. Bork's critique can thereby overlook Justice Douglas' two related film industry opinions that directly follow Griffith. See supra note 270 .

278. See R. BoRk, supra note 1 , at $141-42$, and Bork, supra note 162 , at 19 , for an expanded Griffith critique. A brief relevant market analysis introduces the economic circumstances underlying the master agreement and undermining Bork's arithmetic simplification. Given an initial proposition that full-length films describe the product market, there are several possibilities for subdividing that market. Here, a reasonable definition of relevant geographic market is the area in which the chain operated. A traditional demarcation posits product submarkets of first- and second-run exhibitions. The appeal of second-runs, if described by the amount we are willing to pay for them, is less. This formulation suggests a way other than functional equivalency to describe the relation between first- and second-run exhibitions of films. The economic idea of cross-elasticity of demand asks how ticket price changes of first-runs relate to the quantity of tickets sold to second-runs; more rigorously, cross-elasticity is the ratio between percentage changes in first-run ticket prices and secondrun tickets sold-here, runs of the same film. The analysis is more complex with runs of multiple films.

That is, how close is the competition between these two submarkets? Begin by assuming some price difference between them. The difference can reflect lower or higher prices: If there is no 
As an initial matter, can the Court's theory rest upon the proposition that individual distributors would pay the monopsonist theatre chain twice? A closer look at industry practice uncovers that very possibility. The salient inquiry finds that distributors did not license their films for flat fees but rather for percentages of exhibitors' revenues. 279 Several implications emerge. First, any distributor could expect higher revenues from one chain of eighty-five theatres than from thirty-two individual ones, simply because of the increased number of theatres. Even if given an either/or choice, the distributor would pay more to deal with the eighty-five theatre chain. This implication is significant because it represents a second source of theatre chain power-not only its monopoly towns but also its larger number of screens. The Court twice recognizes the attraction of sales volume, ${ }^{280}$ but Bork misses this second power source and thereby the possibility of an economically rational second payment.

Thus far, it appears that we have a doubly underpowered distributor, which makes a double payment theory tenable. Still, it need not follow that the distributor paid twice in the way Bork describes. Rather, it is possible that the distributor not only paid more, but also made more profits. A second implication of the industry practice of licensing fees based on revenues is the distributor's potential benefit derived from the chain's monopoly position: Monopoly ticket prices can increase the chain's revenues and thus can benefit the distributor, the theatre chain, or both. At the very least, the distributor and the theatre chain share an interest in increasing revenues. Does the chain with its double dose of monopoly power win all of those profits? Or does the distributor participate in them? Bork never reaches this question because he founders on the power issue. Nonetheless, the distributors' bargaining power merits

accessible first-run theatre, then a film, though shown later, can get a "first-run" price. Within each submarket, as the number of competing theatres increases, the ticket prices decrease. It is easy to understand the chain's interest in excluding first-run competitors: a monopoly ticket price can be charged. Yet in order to receive that profit-maximizing price, the chain must also enforce an adequate clearance between first- and second-runs. See, e.g., Schine Chain Theatres, Inc. v. United States, 334 U.S. 110, 115 n.6 (1948) (clearance is the elapsed time between runs of the same feature within an area or in specified theatres). As the time period between them decreases, ticket price competition between them increases. We are willing to pay a lot more now if we must otherwise wait six months to see a desirable film for less. But if we need only wait one month or two weeks, we tend to resist ticket price differences. The chain's receipt of clearances over competing theatres was a necessary element for effective foreclosure of competition in the first-run market. See also United States v. Paramount Pictures, Inc., 334 U.S. 131, 144-45 (1948) (distributors fixed prices).

279. Schine Chain Theatres, Inc. v. United States, 334 U.S. 110, 121-22 n.10 (1948).

280. Griffith, 334 U.S. at 107-08. Schine Chain Theatres, Inc. v. United States, 334 U.S. 110, 115 (1948). There were a few fiat license fees. United States v. Paramount Pictures, Inc., 334 U.S. 131, 141 (1948). 
attention - not only to elucidate the distributors' position but also to provide the context for Bork's image of incipiency.

Did the distributors have any power? Even if we begin by assuming that individual distributors were disciplined by rivalry, their competition was imperfect and probably unworkable. Each of only eight distributors had exclusive rights to a substantial number of nonidentical films and thus each had market power. ${ }^{281}$ The eight film distributors and their corporate parents, including the five major film producers, enforced their pricing interests by agreeing among themselves and with their licensees on minimum ticket prices. ${ }^{282}$ Moreover, the five major film producers had interests, individually or jointly, in over 1500 theatres. ${ }^{283}$ With that brief description of economic circumstances, the theatre circuit no longer looks so powerful in its bargaining with distributors-despite its own second source of power and despite its domination of first-run theatre rivals. Whatever the balance of power between distributor and chain, each certainly had market power vis-á-vis its own rivals. It seems likely, therefore, that the master agreement can be characterized as an instrument for coordinating market power, for more effective exploitation, if each party believes that it will increase profits through cooperation. ${ }^{284}$ Such cooperation makes sense to the extent of their shared interests-their desire to control the film exhibition market for the purpose of increasing revenues and monopoly profits. ${ }^{285}$ While the imposition of clearances solidifies the

281. Griffith, 334 U.S. at 103; Schine Chain Theatres, Inc. v. United States, 334 U.S. 110, 115 (1948).

282. United States v. Paramount Pictures, Inc., 334 U.S. 131, $141-42$ (1948).

283. Id. at 150 .

284. Lowering transaction costs is an acceptable motivation. See Schine Chain Theatres, Inc. v. United States, 334 U.S. 110, 118 (1948); Griffith, 334 U.S. at 108.

285. The agreement also reflects their conflicting interests-their efforts to win those profits from one another. It is in the division of these revenues that the parties' relative bargaining strengths take effect. Such allocation involves bargaining along three dimensions. First, distributors want to increase the percentage of revenues paid, while exhibitors want to decrease it. Second, each might have a different profit-maximizing ticket price. Finally, each has a different optimum clearance between first- and second-run showings. The interplay among all three factors determines the effective revenue allocation. For a fuller description, see Schine Chain Theatres, Inc. v. United States, 334 U.S. 110,121 n.10 (1948).

The master agreements' particular revenue percentage provisions are not mentioned in the three related cases. But see id. at 153-56 (regarding national formulas); id. at 156-59 (regarding blockbooking). In contrast, ticket price and clearance provisions occupy the Court's attention in all three opinions. See supra notes 281-83 and accompanying text. The industry combined to regiment all price competition-whether among different producers, one producer's various films, or multiple showings of any single film. For an argument that tracks the district court's analysis, but in the context of resale price maintenance, see generally Liebeler, Intrabrand "Cartels" Under GTE Sylvania, 30 UCLA L. REv. 1 (1982). It is clear from Justice Douglas' opinions in all three cases that the Court was aware of the motion picture industry-wide foreclosure of competition. See United States v. Paramount Pictures, Inc., 334 U.S. 131, 142-46, 150-52 (1948); Schine Chain Theatres, Inc. v. United States, 334 U.S. 110, 116 (1948); Griffith, 334 U.S. at 108. 
chain's hold on the first-run movie market, that practice also benefits the distributors. ${ }^{286}$ The market differentiation engendered by multiple-tier price discrimination benefits distributors-and producers-since they can expect more revenues and more profits industry-wide than they can from a single-price strategy. ${ }^{287}$ More revenues and percentage-based licensing fees means higher licensing fees to distributors. In short, clearances in combination with minimum ticket prices support an industrywide profit-maximizing strategy of price discrimination that benefits both chain and distributors.

If the Court subscribed to Bork's unitary purpose of wealth maximization, such product differentiation and price discrimination would be viewed as beneficial. The Court in Griffith should applaud the wealth maximizing effects of the practices. To a free-marketeer like Robert Bork, the only problem might be the price-fixing conspiracy. ${ }^{288}$ But the Court does not hold to one unrivaled purpose; it is concerned with the economic effects of market power coordination. Bork insists that a distinction between competitors and competition must be honored; concern for the former is labeled protectionism. ${ }^{289}$ But when a movie theatre circuit's only competition in town is one rival theatre that is excluded from bidding for and exhibiting films, concern for individual competitors and for competition are distinguishable only in the abstract. ${ }^{290}$ Nevertheless,

286. That benefit can be understood as follows: from any competing theatre's perspective, the master agreement excludes the chain's rivals and allows the chain to engage in monopoly pricing. Even if individual rivals show a particular film later, after clearance, they must charge lower ticket prices to attract customers. Regarding lower licensing fees, see Schine Chain Theatres, Inc. v. United States, 334 U.S. 110, $121-22$ n.10 (1948). Alternatively, first-run theatres might choose to show independent distributors' films or those not pre-empted. Independent first-run theatres face two fates: either they are simply excluded from desirable movies or they must compete with secondrun theatres for later exhibition.

If the former, they must then content themselves with less desirable films and presumably lower profits. Nonetheless, distributors benefit to the extent that such films generate additional revenues. If individual theatres compete with second-run theatres for later showings, they might have some Iocational or other advantage over them and receive clearances; on the other hand, they might face second-run chains. In any event, further stratification would tend to benefit the distributors-further price discrimination, even lower ticket prices, would presumably attract some movie-goers who would not have paid higher ticket prices. Industry ticket revenues would be higher and thus licensing fees would also be greater.

287. For a clear description of price discrimination as a profit-maximizing strategy, see Bowman, Tying Arrangements and the Leverage Problem, 67 YALE L. J. 19, 25-27 (1957) (the only material consequence of tying arrangements is the additional profits resulting from price discrimination).

288. See Bork, supra note 162 , at $2 \mathrm{I}$. His only other enunciated concern is with horizontal mergers to monopoly. R. BoRk, supra note 1, at 217-24. Cf. Dewey, Information, Entry, and Welfare: The Case for Collusion, 69 AM. EcoN. REv. 587, 593-94 (I979) (pro-cartel argument positing that legalizing collusion might not harm economic welfare).

289. Bork, supra note 162 , at 13,15 , I8.

290. The Court is also concerned with other discriminatory practices. United States v. Paramount Pictures, Inc., 334 U.S. 131 (1948). These include clearances, id. at 144-48; pooling agree- 
Bork concludes that the corpus of proper antitrust policy must be purged of the Court's economic theory of leverage.

Bork categorically describes the Court's social and political purposes as unacceptable because he fails to recognize therein any rationality-economic or otherwise. But even within the narrow category of economic rationality, the Court's leverage logic is more complex and more appealing than the label of "double counting" allows. To offer Griffith as an opinion ill-founded in a mirage of double-counting, Bork must ignore the competitive context and focus on individual competitors-the chain and the distributor-in splendid isolation. The market power of each is underestimated. ${ }^{291}$

In sharp contrast, the Court takes a more studied view of a cartelized industry and its excluded class of competitors. Individual theatres are losers, while both chains and distributors/producers are winners. Clearly the Court's theory need not rest upon an advantage of double counting. Rather, it can find added strength in the market power of both parties to the master agreement-that common lever set upon a fulcrum of mutual benefit from increasing revenues. Yet their interests are not identical; they do exert some bargaining power against one another. Thus, such leverage also combines multiple market forces at a second point of resistance. But because the Bork vignette depicts only the second point-the tension between distributor and theatre chaineven a narrow economic assessment of the Court's efforts is lacking. It ignores industry practices amounting to de facto vertical integration. When Griffith is read within its industry context, it becomes clear that Bork's bargaining scenario excludes all evidence of the Court's concern. By overpowering individual competitive resistance, these contracts between a powerful chain and powerful distributors structure the market to foreclose all theatre competition. ${ }^{292}$ As a result, both parties maximize their profits. The chain can charge monopoly ticket prices; the distributor receives higher licensing fees from the chain and benefits from optimized secondary showings-from price discrimination. Although Griffith is offered as an example of the Court's double counting, it appears to represent instead an instance of Bork's mistaken discounting of market power and blindness to vertical cooperation.

ments, id. at 149-53; formula deals, master agreements, and franchises, id. at 153-56; and blockbooking, id. at 156-59.

291. Bork's treatment is not offhand. He repeats it 11 years later in R. BoRK, supra note 1 , at 141-44.

292. Griffith, 334 U.S. at 107. 
3. Typhoid Fever and Quarantine. Both Bork's economic argument and its analogical predecessor are ultimately unconvincing. Yet if we take Bork at his word, leverage theory is unacceptable even if logical. It is unacceptable because it does not comport with wealth-maximization purposes, because it effects other social and political purposes-in particular, the "incipiency" doctrine. But the choice of Griffith as an example of incipiency raises a significant question about Bork's alternative "Sherman Act proportions" standard. If not the cartelized film industry, if not the theatre chain with its master agreement, then how much market power and what sort of structure is necessary to meet Bork's standard?293 Apparently, the Griffith pattern does not reach that Sherman Act standard. Rather, it carries forward an incipiency doctrine that Bork deplores and fears.

Bork calls the incipiency concept "a protectionist disease."294 The idea that something less than monopolization should amount to competitive injury, we are told, carries the germ of an anti-antitrust virus into the healthy body of economics-nurtured public policy: "[T] he focal point of the infection is the Clayton Act and its Robinson-Patman Amendment. . . . That makes [it] the "Typhoid Mary" of the protectionist disease."295 After the Griffith discussion, Bork identifies the contaminated carrier of this contagious disease. Griffith represents a diagnostic study of the antitrust corpus reeling from its encounter with infectious social and political values. It is Sherman Act doctrine already infected by "Typhoid Mary."296 Double counting appears to demonstrate the Court's otherworldly vision of leverage theory. Bork presents us with symptomatic evidence that a protectionist virus already threatens the doctrinal health of the Sherman Act. In short, he offers double counting as proof of viral delirium - as confirmation of irrationality.

The indicated treatment purports to be a purgation, a cleansing of the doctrinal body. Whatever normative prescriptions are later applied, any infection carrier-any Typhoid Mary-must first be quarantined. First and foremost, the social necessity of such health maximization requires us to protect and cleanse the proper body of antitrust policy and doctrine. A failure to protect the host from such parasitic invasion en-

293. In Bork's world, that question turns out to be immaterial. Market conduct-like price discrimination-that maximizes wealth never reaches a Sherman Act proportion. Bork, supra note 162, at 18. Only rules against cartels and large horizontal mergers might be retained. Id. at 21 . Thus only by neglecting the companion cases to Griffith can the Bork narrative purport to countenance such cartelized market behavior.

294. Id. at 18.

295. Id.

296. See Levi, supra note 157, at 62 (the Robinson-Patman Act is a threat to the virtue of the Sherman Act). 
dangers the very life and vigor of that host-the free-market ideology of competition. ${ }^{297}$

Reminiscent of the text's Euclidean analogy in both form and purport, this extended metaphor depends upon our acceptance of several underlying premises. First, we must connect "other social and political purposes" to protectionism, then to virus; the Clayton and RobinsonPatman Acts to Typhoid Mary; and the Sherman Act to market healthmaximization, then to body politic wealth-maximization. Then we can see how the amendment has corrupted the Sherman Act-as an infected carrier brings an external virus into a previously healthy system. Once we accept the imagery of that dramatization, the structural logic becomes apparent. First, the nomenclature of "Typhoid Mary" portrays the infection's source as alien, outside the system. Next, the virus is dangerous-protectionism kills healthy competition. Finally, the endangered health of the host necessitates immediate treatment for degenerate argument-other social and political purposes must be driven from the body of proper antitrust policy. This emergency scene calls for immediate administration of strong medicine: a powerful prescription of wealth maximization. Still, we should not ignore the possibility that this medicine may have harmful side effects. ${ }^{298}$ It may be that Bork's remedy will destroy both virus and body.

As a context for considering that possibility, let us shift the scene from Bork's infection/healthy body antinomy to the unmelodramatic opposition of anomaly/system. If we abide by an isomorphic formulation of Bork's portrayal-that is, that a Sherman Act notion of competition describes a coherent system and that the Robinson-Patman Act adds an anomalous element-then another structural logic can emerge. ${ }^{299}$ In general, the development of explanatory systems involves an identification and exclusion of anomaly. The process of rigorous system definition throws out elements tentatively deemed anomalous. Yet like the relation between figure and ground, anomaly and system depend upon one another for recognition. Moreover, their status is uncertain and exchan-

297. Bork, supra note 162 , at $18,21-22$.

298. These side effects are not mentioned in the Bork speech; but see, for example, Kornhauser, A Guide to the Perplexed Claims of Efficiency in the Law, 8 HofsTRA L. REV. 591, 599-604 (1980) (utilitarian objections to wealth maximization); Bebchuk, The Pursuit of a Bigger Pie: Can Everyone Expect a Bigger Slice?, 8 HoFsTRA L. REv. 671, 677-79 (1980) (nonneutrality of wealth maximization); Markovits, supra note 149, at 819-27 (criticism of allocative efficiency analysis as underestimating efficiency of policies designed to aid the poor).

299. See M. FouCAulT, Power/KNOWLEDGE, supra note 4, at 78 (genealogical history of theory of system and anomaly); see generally T. KUHN, supra note 18 (interrelationships between ideas of system and anomaly in structuralist historiography of science); N. WEINER, THE HUMAN USE OF HUMAN BEINGS (1954) (information theory-its elements of information and noise-founded in entropy as system and negentropy as anomaly). 
gable. Each can be figure for the other as ground, anomaly for the other as system. ${ }^{300}$

Given this transformation of Bork's metaphor, necessity no longer takes the epidemiological form of quarantine. No contagion threatens and demands isolation. Rather, necessity takes the shape of mandatory choice between one form or another of figure/ground relation. Yet we confront a logically indeterminable choice of alternatives-each can serve as figure or ground, each as anomaly or system; if there is no natural or pre-ordained background system-no single right choice-how is it that we agree to call some elements a system and others anomalies? We base analysis and other forms of argument on ordering principles founded in our social and political values. That is, we build metaphorical visions of our interests and desires. ${ }^{301}$

Bork's invention of an ill-founded model of necessity is such an exercise in political choice. Its kinship to its imaginary companions-nonEuclidean premises and double counting-derives from a common logic of infection/symptom - of cause/effect. Unworldly visions and irrational ravings are said to attend this typhoid fever. But this evidence has been called into question. This section has already suggested how non-Euclidean premises and double counting can be characterized as worldly and rational. Without Bork's symptomology, what do we make of his diagnosis? Is this viral condition typhoid fever or is it something else? Is it a malignant strain at all?

The foregoing questions suggest another and perhaps healthier view of antitrust argument's convalescence-its endemic disorder. If the viral strain appears benign, then we must return to the operative question earlier posed. Will Bork's remedy destroy both virus and body? We have witnessed the danger of ignoring side effects-a good dose of wealth maximization risks other social and political purposes that wait just

300. Note how the LEA argument co-opts both perspectives in one respect. The 1955 AG Committee Report reformulated the 1890 Sherman Act according to its economic metaphor of workable competition and responded to that mirrored image by a reversal of its own. See 1955 AG Comm1TTEE REPORT, supra note 22, at 318-36. It rescues the Standard Oil rule of reason with "modern developments," with an economic image that follows and thereby purports to supercede the 1914 and 1936 enactments. The Committee transforms the first antitrust statute into the last. Bork, on the other hand, argues for Sherman Act supremacy because of its prior historical position. Apparently, therefore, whether first or last, the Sherman Act stands in a preferred position vis-à-vis later legislation.

301. See On Truth and Falsehood in an Extra-Moral Sense, in 2 THE CoMplete WoRks of FRIEDR1CH NIETzSCHE 179 (O. Levy ed., M. Mugge trans. 1911) (dead metaphors are dailgerous because encoding of interests and desires is forgotten; thus words are mistakenly taken as true or false representations rather than as metaphors serving interests and desires); Serres, supra note 158, at 260 (ordering principles and powerful argument). 
outside the domain of antitrust. ${ }^{302}$ And what if those outside purposesthose dreaded viruses - are always already present here within antitrust's doctrinal boundaries? Then we cannot be sure of an external origin-a Typhoid Mary. Perhaps this infectious state is an original one. Certainly we should not ignore overwhelming documentary evidence that the body of antitrust argument-from The Case of the Monopolies ${ }^{303}$ in 1602 to the present-has carried the virus of social and political purposes. Since both corpus and virus have survived for almost 400 years, it seems metaphorically sound to assume that the strain is not deadly. Indeed, the condition might even be necessary for the body's survival.

This symbiotic reconception of necessity calls for treatment very different from the quarantine and purgation envisioned in Bork's feverish imagery. His metaphor of epidemic only continues by other means the LEA's ideological warfare against social and political purposes symbolized by the Robinson-Patman Act. ${ }^{304}$ Edwards envisions dark democratic origins and unavoidable political zealotry. Rowe finds legal schizophrenia. Bork advances a common desire to isolate, institutionalize, and boycott the Act and all that it symbolizes. Each commentator wishes to "protect the virtue of the Sherman Act." That is, each wants to protect it from protectionism. The contradiction of such freemarketeering is obscured by the imagery of zealotry, madness, and viral dementia. But if the corpus of antitrust argument is recognized as already-and always-impure, then it is the free-marketeers' rage for purification that is dangerous. If the traditional rivals for antitrust argument-law and economics, Jeffersonian entrepreneurialism, fair competition, equitable distribution, and common law methodology-instead compose a vigorous body of impure antitrust argument, then quarantine describes dangerous treatment. Then the LEA's prescription of antitrust argument monopolization would kill both host and parasite by its exclusion of an always already present anomaly-the viral rivalry that inhabits and apparently sustains an antitrust ideology of competition.

Most commentators and critics who think about antitrust accede to Bork's quarantine and thus participate in its social and political purposes. This boycott seeks to transform the Sherman Act into a pure symbol of the ideology of competition. Once we engage in such symbolic transactions to sustain production of purified antitrust argument, we need no longer choose among competing argument suppliers and thus we

302. Bork, supra note 162 , at 13 .

303. 11 Co. REP. 84 b, 77 ENG. REP. 1260 (K. B. 1602). It may be interesting to note that the Posner and Easterbrook casebook begins with excerpts from The Case of the Monopolies. POSNER \& EASTERBROOK, supra note 223, at 1 .

304. See R. BORK, supra note 1 , at $242-45$. 
need not justify preference. That position is desirable-comfortablebecause it allows us the illusion that we need not make and justify value choices-social and political judgments. Rather, we deal exclusively with one supplier, with the antitrust industry's monopolistic argument, the LEA. Now we can spend our time arguing about intramural questions like the proper form of cost for purposes of measuring predatory pricing. ${ }^{305}$ We feel more comfortable taking measurements than making judgments. We feel more comfortable within the LEA.

\section{The Strain of Monopolization: A Logic of EfFiciency}

This section demonstrates how legal commentators and critics both depend upon and perpetuate the LEA's monopolization of price discrimination argument. ${ }^{306}$ To introduce this section's hermeneutical methodology, ${ }^{307}$ a brief analytical vignette illustrates a Harvard School form of monopolization. Following that, an analysis of Richard Posner's Chicago School approach finds an isomorphic monopolization, then takes Posner's work as representative of LEA strategies to map out an efficiency-based logic for price discrimination doctrine.

\section{A. An Areedaic Vignette of Monopolization.}

Areeda and Turner's antitrust treatise does not deal directly or systematically with the Robinson-Patman Act. However, it does methodically apply an economic notion of price discrimination in its analysis of various doctrinal categories, including monopolization..$^{308}$ Thus, a barrier between the Robinson-Patman Act and the "proper" antitrust

305. For an interesting dramatization of the vagaries of predatory pricing doctrine as well as an up-to-date bibliography, see generally Brodley, The Goals of Antitrust-Pretrial Hearing No. 1: $A$ Verbatim Account of an Imagined Proceeding, 28 ANTITRUST BuLl. 823 (1983).

306. Not surprisingly, commentators agree on this point. Compare Baker \& Blumenthal, The 1982 Guidelines and Preexisting Law, 71 CAL.IF. L. REv. 311, 317 (1982) (suggests that 1982 Department of Justice Merger Guidelines are economic, not populist) with Spivack, The Chicago School Approach to Single Firm Exercises of Monopoly Power: A Response, 52 ANTITRUST L.J. 651, 655 (1983) (suggests that three recent cases herald a new trend).

307. By hermeneutics, I mean a reconstruction of the motivations-the imaginative structureof a text or set of texts. Whether or not this contextualization coincides with an author's expressed intent, it neither depends upon nor gives special credence to such intent. Thus, for example, this methodology views legislative history as nothing more than one source for reconstructing the imagination(s) that produced a piece of legislation. At the same time, hermeneutics is to be distinguished from empiricism, which proceeds from the belief that proper methodology holds the promise of validity. In sharp contrast, hermeneutics proceeds from two notions that prescribe a more modest enterprise: first, that the idea of validity is a dangerous fiction; and second, that we can expect no more than principled interpretation. See, e.g., H. GADAMER, TRUTH AND METHOD 289-305 (1975) (discusses the exemplary significance of legal hermeneutics); Rorty, Hermeneutics, General Studies and Teaching, in 2 Synergos: Selected Papers From the Synergos Seminars 1-16 (1982).

308. 3 AREEDA \& TURNER, supra note 7, at 148-94 (discussing various pricing policies). 
laws, ${ }^{309}$ and between the statute and a proper idea of price discrimination, is maintained. Yet, Areeda's antitrust casebook seems to dishonor the boycott: One of the text's seven chapters-some 166 pages-is devoted to the statute. ${ }^{310}$ Nevertheless, the chapter's placement at the end of the text may encourage the reader to neglect the Act. ${ }^{311}$ Moreover, the author's preface, stressing the "unity of the subject matter" 312 and "the usual progressions" 313 of topic presentation, includes the following footnote: "Chapter 7 (price discrimination) is rather self-contained and could be treated any time." 314 Or, perhaps, not treated at all. Apparently, it falls outside the subject's "unity" and its "usual progressions." In short, Areeda's "self-contained" chapter design suggests that the Act has nothing to do with or to say about six preceding chapters of unified and progressive antitrust doctrinal development.

In contrast, a doctrine of economic price discrimination appears prominently in four chapters treating monopolization, patents, tying, and vertical integration. ${ }^{315}$ The structural logic of these two texts supports an inference of statutory exclusion and consequent doctrinal monopolization.

\section{B. An Isomorphic Structure: Posnerian Monopolization.}

The remainder of this section investigates the form and content of Richard Posner's two 1976 antitrust monographs, one well-known and the other a well-kept secret: Antitrust Law: An Economic Perspective 316 (hereinafter Antitrust Law) and The Robinson-Patman Act ${ }^{317}$ (hereinafter The RPA ), respectively. The former counsels policymakers to focus on the "common core" of antitrust doctrine-"the economic theory of monopoly." 318 Posner promises that he will discuss only major antitrust problems and will "ruthlessly ignore the peripheral areas." 319 Thus, his "central concerns" permit only "incidental discussion of the Robinson-

309. See Baxter, Separation of Powers, Prosecutorial Discretion and the "Common Law" Nature of Antitrust Law, 60 TEx. L. REv. 661, 662 n.6 (1982) (Robinson-Patman Act "is not regarded as a true 'antitrust' law").

310. See P. AREEDA, supra note 4, at 1050-1216.

311. The point is that the subject's placement in the last chapter suggests its optional nature-its marginal importance.

312. P. AREEDA, supra note 4 , at xxxvi.

313. Id. at xxxvii.

314. Id. at xxxvi n.2.

315. See id. at 1348 (index).

316. ANTITRUSt LAw, supra note 6.

317. ThE RPA, supra note 10.

318. ANTITRUST LAW, supra note 6, at 4.

319. Id. 
Patman Act."'320 Yet Posner does apply an economic idea of price discrimination to other antitrust issues.321 While the statute is considered peripheral, the idea of price discrimination is a central concern. Thus The $R P A$, by its very dedication to the statute, has identified itself as a work of only peripheral importance and of merely marginal significance. ${ }^{322}$

Notwithstanding that structural logic, a performative logic suggests that authorizing power resides not at the center, but at The RPA's marginal location. In other words, it may be The RPA's citation of Antitrust Law that prompts us to treat Antitrust Law as a source of power. Authority can be seen to derive from the conduct of citation rather than from the source cited. Thus, references at the margin can be seen as the origin, grant, or exercise of authority as well as simply a call to authority. 323 In short, a "true" center cannot be observed or proved.

Yet Posner's center/margin structure is not controversial. No one would place the Robinson-Patman Act at the center of antitrust law. The success of The RPA's rhetorical style depends not only upon our prior belief in the centrality of Antitrust Law and its politics of economic efficiency but also upon our acceptance of arguments repeated from earlier texts. Posner repeats arguments from Edwards, ${ }^{324}$ the 1955 AG Committee, ${ }^{325}$ and especially from Rowe. ${ }^{326}$ What is new, what is possible only now that the LEA dominates antitrust argument, is the presumptive

320. Id. at $\mathrm{x}$. Though Posner calls the Act a "major antitrust statute," id. at $\mathrm{x}$, its importance is apparently peripheral.

321. Id. at 173-74, 193-94.

322. This structure of core-periphery, of center-margin, is further reflected in the cross-referencing pattern of the two books. Antitrust Law is cited for authority on at least eight occasions, while no return references are made. Although the citation pattern may reflect the order of publication, an equally strong inference is that only one text is authoritative. Antitrust Law, given its central position, need not and cannot call upon its antinomic twin, given its location at the margin.

323. A second performative argument that authority does not reside at the center-in Antitrust Law-issues from the text's very assertion of centrality: Antitrust Law announces an intent to deal only with topics of major importance and to ignore peripheral areas like the price discrimination statute. ANTITRUST LAw, supra note 6, at $\mathrm{x}$. Its self-proclaimed center of gravity rests upon a characterization and an exclusion. The RPA is labeled peripheral and pushed away to the margin. Why does not the Act's exclusion render the Antitrust Law marginal or otherwise seriously deficient? Our acquiescence derives from antitrust imaginations already captured by arguments for the Robinson-Patman Act's exclusion. It depends upon our participation in a systematic exclusion to fabricatc a system, in a doctrinal boycott to protect proper argument. In sum, it testifies to the monopolization of our antitrust imaginations.

324. Compare ANTITRUST LAW, supra note 6, at 231 (Department of Justice Antitrust Division's enforcement program depicted as political zealotry) with C. EDWARDS, supra note 21, at 657 (politics of price discrimination as zealotry).

325. Compare ANTITRUST LAw, supra note 6, at 62 (price discrimination one of 10 elements in oligopoly pricing analysis) with 1955 AG COMMITTEE REPORT, supra note 22, at 333 (price discrimination one of 12 elements in workable competition analysis). 
and unrivaled value of efficiency. Moreover, argument in favor of other social values is viewed as argument opposing efficiency. Thus, issues that once were points of vigorous argument are now resolved in the comfortable presumption of power. The Posner texts' rhetoric of authority derives from a status quo of monopolization and exclusion. Where the earlier LEA commentators and critics argue for the Robinson-Patman Act's exclusion from proper, healthy, and sane antitrust laws, Posner finds a quarantine in place. Here, we find no mention of typhoid fever and schizophrenia, no traces of epidemic and madness; instead we hear strains, if at all, of silenced competition-of monopolized rivalry for antitrust argument supply.

This section investigates the kind of analysis produced in the now unrivaled market for price discrimination argument. The first subsection examines The RPA's disposition of noneconomic concerns and finds inadequate Posner's interplay of limited definition and unexplained presumption. Thus, it finds unwarranted the author's ultimate claim-that he need not confront the political value questions of protection and competition. The next subsection argues that this rhetorical failure is compounded, not averted, by Posner's unconvincing attempt to maintain LEA orthodoxy - by separating monopolistic from sporadic price discrimination. Founded in economic efficiency, this distinction ultimately calls for a political economy of conglomerate competition.

1. Monopolized Argument: Exclusion and Presumption. The success of The RPA's argument depends upon the strength of antitrust presumptions against the value of the Act in particular and noneconomic concerns in general. ${ }^{327}$ It imposes a burden of proof on those who believe that the antitrust laws should serve values other than efficiency and on those who believe that the Robinson-Patman Act should not be repealed.

The text's dismissal of nonefficiency objections to price discrimination proceeds in four stages. The first two imitate Rowe's narrowing of the legal doctrine and Bork's foreclosure of social policies to be served. The third recounts a legislative history mired in indeterminacy. The last stage uses an empirical strategy to assert the statute's ultimate undesirability.

326. The distinction between legal and economic price discrimination is based on the misreading of Anheuser-Busch that first appeared in F. RowE, supra note 22, at 95-97. See supra note 202 and accompanying text.

327. These values include everything except efficiency. THE RPA, supra note 10 at 3-4; ANTITRUST LAw, supra note 6 at 4, 22. Such a limited notion of economic value is unusual, if not controversial. 
a. First exclusion: legal price discrimination. The RPA begins its doctrinal analysis by echoing Rowe's erroneous definition of legal price discrimination-it too cites Anheuser-Busch for the proposition that the legal doctrine requires "simply a price difference." ${ }^{28}$ But $T$ he $R P A$ later contradicts its own reference. In a discussion of the section 2(a) costjustification defense, Posner states that "the difference between what is part of the prima facie case and what is part of the defense is unlikely . . . to be a critical factor in deciding most cases." 329 Embedded in that comment is a clear recognition that the Court requires more than "simply a price difference." A prima facie case and the cost defense approximate the economic idea of price discrimination-differential profits. ${ }^{330}$ Yet Posner chooses to focus on their purported difference. He claims that the Sherman Act provides sufficient and proper coverage for the economic idea of price discrimination. ${ }^{331}$ In short, Posner argues that monopoly power must be proved. Whether or not the LEA's political position is appealing, Posner's exegesis rests in artful caricature of the legal doctrine. As it does in Rowe's book, casuistry initiates this study of price discrimination.

b. Second exclusion: social grounds. In contrast to his dismissal of the legal idea, Posner asserts that the economic idea of price discrimination constitutes "evidence of monopoly power," 332 that its persistent practice tends to waste resources even beyond the loss resulting from a single-price monopoly. 333 Finally, Posner argues that it is "perhaps obnoxious on social grounds." 334

The second stage of eliminating nonefficiency objections to price discrimination presents and then discredits the social grounds "for protecting small business from more efficient big business." 335 Because Posner

328. THE RPA, supra note 10, at 2 (citing FTC v. Anheuser-Busch, Inc., 363 U.S. 536 (1960)).

329. Id. at 40.

330. See id. at 3.

331. Id. at 22-23 (suggesting that the Supreme Court could have obviated the need for the Robinson-Patman Act by a more far-sighted decision in Standard Oil); ANTITRUST LAw, supra note 6, at 212-17 ("Section 1 of the Sherman Act . . . is sufficiently broad to encompass any anticompetitive practice worth worrying about . . .").

332. THE RPA, supra note 10, at 5 (indicating, however, that such evidence is not conclusive).

333. Id. at 8-12.

334. Id. at 7.

335. Id. at 16. Posner's formulation of social grounds raises several questions. First, why envision the protection in terms of more efficient big business? Why not all big business? If the costjustification defense for charging a lower or higher price is to make any sense at all, it must be read to allow for productive efficiency differences. Next, "all big business" as a category would not correspond to a statute focused on conduct, unless all firms by their very size are found to price discriminate. Although such a per se illegality interpretation is possible given the differing competitive conditions faced by big businesses, not even the much-maligned opinion in Utah Pie Co. v. Continen- 
does not describe a third category of norms, efficiency and social grounds appear to comprise the argument's ethical universe. Given this, one might expect that the social grounds category would include a large set of values. It does not. Rather, Posner narrowly defines the category in terms of one particular concern. As a result, his analysis is incomplete and misleading. He argues that to protect small business "by trying to limit price cuts given to competing big businesses would be an oblique, very costly, and probably ineffective method. A lower tax rate on small firms, for example, would probably be a preferable means for accomplishing this objective."336

A lower tax rate would increase the profits of small firms by redistributing income. Does Posner's "example" equate social grounds with redistribution? Apparently so. First, Posner offers no other examples of social grounds. ${ }^{337}$ Second, he describes price discrimination's "perhaps obnoxious" character on social grounds defined as "distribution of income and wealth."338 Besides overlooking a tax break already directed to small corporations, ${ }^{339}$ this radical foreclosure of antitrust grounds omits a significant social concern-the process of fair competition.

The importance of fair competition cannot be denied. Here it barely escapes mention. While Antitrust Law asserts that "the antitrust laws were never intended to protect unfair competition,"340 neither of Posner's texts makes the short yet dangerous leap to a claim that the antitrust laws were intended to protect fair competition. Yet it seems uncontroversial that the attractiveness of the competitive system depends upon our perception that the competitive process is fair and meritocratic. ${ }^{341}$ Whether described in ethical terms like "fairness" or in ide-

tal Baking Co., 386 U.S. 685 (1967), has been so read. Moreover, as The RPA's references to Federal Trade Commission enforcement illustrate, that agency has not limited its efforts to prosecuting big businesses. See THE RPA, supra note 10, at 16 ("small-business purchasing cooperatives have been a favorite target of Robinson-Patman enforcement"). Thus we seem to be left with some other subset of business, perhaps one that engages in statutorily proscribed price discrimination. The issue so rephrased seems to be even more compelling than protecting small businesses from more efficient big businesses-although we might want to do that. See E. F. SCHUMACHER, SMALL is BEAUTIFUL: ECONOMICS AS IF PEOPLE MATTERED 146-59 (1975) (argues the sociopolitical desirability of intermediate technology). Cf. Federal Trade Commission, Relative Efficiency of Large, MEDIUM-SIZED, AND SMALL BUSINESS 12-14 (TNEC Monograph No. 13, 1941) (large size most efficient in $11 \%$ of total tests, medium size in $55 \%$, and small size in $34 \%$ ).

336. THE RPA, supra note 10 , at 16.

337. Taxation is also the sole "example" in Antitrust Law. See ANTITRUST LAw, supra note 6, at 4,20 .

338. THE RPA, supra note 10 , at 7 .

339. See, e.g., I.R.C. $\$ 11$ (b) (1984) (first $\$ 100,000$ of corporate income subject to lower rates).

340. ANTITRUSt Law, supra note 6, at 210.

341. Brodley, Joint Ventures and Antitrust Policy, 95 HaRv. L. REv. 1523, 1533 (1982) ("Exclusion of a business rival by a group of competitors combined in a joint venture may . . . undermine competition on the merits ... This exclusion both offends notions of fairness and impairs the 
ological terms like "individual entrepreneurialism," the antitrust laws certainly provide an appropriate instrument for enforcing the belief that fair competition is important.

c. First presumption: legislative history and efficiency. The RPA does not recognize the process value of fair competition or any social concerns beyond one form of redistribution. Posner grounds that refusal in two presumptions. First, he presumes that the Robinson-Patman Act's legislative history does not clearly indicate that Congress intended to protect social concerns. ${ }^{342}$ Posner traces the statute's roots not only from the Clayton Act, seen as a statement of dissatisfaction with the Standard Oil rule of reason, ${ }^{343}$ but also from the late nineteenth-century trusts to the passage of the Sherman Act. ${ }^{344}$ Finally, Posner asserts that both judicial interpretation of the Clayton Act and the Great Depression of the 1930's "created all sorts of demands for government assistance to businessmen." 345 Here, Posner again echoes Rowe. He views references to competition as efficiency-based and antithetical to social concerns, and denies the logic of the legislative process. ${ }^{346}$ In that context, Posner observes:

The great question raised by the history and language of the . . . Act is the extent to which Congress wanted not merely to provide more effective regulation of . . . price discrimination that [is] inefficient or anticompetitive in some legitimate economic sense, but also (or instead) to prevent price differences that ... might be injurious to segments of the business community that were influential in the enactment of the legislation. 347

Although Posner regards the great question as "largely unanswerable," ${ }^{348}$ his positions on three issues are quite clear. First, only economic sense is legitimate. Second, social concerns are not legitimate or even present. Third, the choice is not between efficiency and social concerns but between efficiency and illegitimate political bargaining. Moreover, the excerpt's syntactic structure contains the very presumption of efficiency's primacy. ${ }^{349}$ Thereby are we led to believe that legislative intent

efficiency of the market mechanism.") (citing North, Structure and Performance: The Task of Economic History, 16 J. ECON. LIT. 963 (1978) (arguing that market participants must be persuaded of system's fairness and legitimacy)).

342. See THE RPA, supra note 10, at 29.

343. Id. at 23.

344. Id. at 17 .

345. Id. at 25 .

346. Id. at 28 .

347. Id. at 27 (emphasis added).

348. Id.

349. The phrases "not merely efficiency" and "instead of efficiency" presuppose the prior presence of efficiency. 
to further efficiency need not be proved; only its substitution requires -proof. Although that unstated yet crucial premise is unsubstantiated, its practical consequence is significant. In effect, efficiency is insulated from the proof requirements imposed on competing social concerns that arguably motivated Congress. So, the argument concludes, the legislative indeterminacy that excludes social concerns does not exclude efficiency. ${ }^{350}$

d. Second presumption: two instances of empirical determinacy. The initial presumption protects the idea of efficiency from the impossible test of factual validation to which social concerns are subjected. Posner's logic then shifts radically from a standard of indeterminacy to one of determinacy. He offers two presumptively determinate facts to establish the unrivaled social value of efficiency. First, Posner asserts that the Act has not been enforced in favor of small businesses. ${ }^{351}$ In support, he reviews the FTC's earlier ill-conceived and now dormant enforcement program. ${ }^{352}$ For example, he points out that small-business purchasing cooperatives were at one time favorite Commission targets. ${ }^{353}$ The Act was not repealed, Posner implies, because the commodity distribution industry's small firms were able to convince Congress to retain it. ${ }^{354}$ How has such a small interest group wielded so much power for so long? Is there support outside that small group for protection against the buying power of chain stores? Perhaps protection against the buying power of chain stores has particular applicability to an industry whose commodity input costs have special significance. ${ }^{355}$ Whether or not the Act's detractors can call such motivation archaic or inefficient, it is not arbitrary.

The second presumptive "fact" is Posner's assertion that "in fact discriminatory prices in the economic sense are surely the exception rather than the rule." 356 Again, he describes a proposition as fact, asserts that it "surely" must be so, and then proceeds without any empirical foundation. Furthermore, this second "fact" seems inconsistent with a later assertion that "below-cost pricing is a rational method of obtaining

350. THE RPA, supra note 10, at 29. Posner questions "whether Congress accepted a view of public policy ... that would go considerably beyond the suppression of economically unjustified price differences." Id. (emphasis added). Again, to go "beyond" efficiency-justified discrimination implies an original position of efficiency: The RPA is sure of a singular congressional public policy founded in efficiency. But that assurance is founded in neither fact nor logic; it is merely presumed.

351. Id. at 16.

352. Id. at 29-34.

353. Id. at 16.

354. See id.

355. Id. at 37. See also ANTITRUST LAw, supra note 6, at 188-93.

356. THE RPA, supra note 10 , at 40 (emphasis added). 
or maintaining a monopoly." 357 Certainly Posner does not mean to suggest that monopoly power is rare or that monopolists, given the opportunity, are rarely economically rational. Instead, some wealth-maximizing firms might evaluate the Robinson-Patman Act as a disincentive to price discriminate and choose its avoidance as the lowest-cost alternative of doing business. In short, perhaps such conduct would increase without the statute. Perhaps not. But given the "fact" that such discrimination occurs infrequently, the Act's effectiveness cannot be dismissed out of hand. ${ }^{358}$

In sum, The RPA stands on two presumptions labeled "facts": (1) the Act has not benefitted small business in general, and (2) monopolistic price discrimination is rare. But juxtaposing these two instances of "fact" can suggest something very different. Perhaps small business has benefitted from less monopolistic price discrimination. To avoid that interpretation, the text must further presume that these two propositions have no connection. All three presumptions accrue to the benefit of one social value-efficiency. Like the earlier argument of the legislative history's empirical indeterminacy, this argument of determinacy is raised against social concerns. Consistency in Posner's empirical argument is limited to its desired conclusion that efficiency is the only proper antitrust concern.

That conclusion is not subject to any scrutiny at all. The foregoing exclusions and presumptions illustrate The $R P A$ 's dependence upon a status quo of argument monopolization-upon prior consensus in the boycott of nonefficiency concerns. For only then can Posner declare that " $[t]$ here is accordingly no occasion for me to reach in this study the ultimate question whether public policy should favor small business." 359 If Posner believed that social concerns have some legitimate claim, then the question would be addressed. If the desirability and possibility of small business benefit were considered, then the ultimate question would demand an answer. But unlike the authors of earlier commentaries and criticisms of the Robinson-Patman Act, Posner need not confront social concerns other than efficiency. He need not take seriously any desire to clarify the Act and consider nonefficiency objections to price discrimination, for such values are now held presumptively improper. This pre-

357. Id. at 19. See also ANTITRUST LAw, supra note 6, at 188-93.

358. This dismissal cannot occur unless Posner somehow attributes deterrence to all antitrust legislation except the Robinson-Patman Act. For a similar critique of anti-Sherman Act "empiricism," see ANTITRUST LAW, supra note 6, at 14-15 (studies which suggest that the Sherman Act is ineffective should be heavily discounted).

359. THE RPA, supra note 10, at 17; see also id. at 37, 41 (the Robinson-Patman Act's beneficial effect on certain small businesses has been too random to provide justification for the Act on social grounds). 
sumption marks the power of the LEA to monopolize our antitrust imaginations, to convince us that the price discrimination statute cannot make sense, that it ought to be repealed. ${ }^{360}$

2. Monopoly and Ideology: A Contradiction Transformed. In addition to its dismissal of nonefficiency concerns, ${ }^{361}$ The RPA also addresses LEA orthodoxy and the distinction posed between the systematic/monopolistic and sporadic/competitive forms of price discrimination. ${ }^{362}$ Posner points out that price discrimination is economically objectionable as a symptom of monopoly or cartel pricing. ${ }^{363}$ In the twenty years since Rowe's book, these categories have been generally accepted as the matrix for analyzing price discrimination doctrine. This subsection demonstrates how the methodology requires social value judgments, not neutral economic analysis. Indeed, Posner's efficiency-based treatment in both The RPA and Antitrust Law not only obfuscates the subject's political dimensions but also transforms a fundamental contradiction between the ideologies of competition and private property. ${ }^{364}$

a. Uncovering a political economy. The LEA analytic matrix purports to distinguish two types of price discrimination: systematic and sporadic. The systematic variety may be a symptom of monopoly power. But it may or may not make economic and strategic sense for monopolists to discriminate. ${ }^{365}$ Thus we cannot identify the systematic genre by an empirical showing of uniformity or regularity. As the earlier analysis of Rowe's distinction has already demonstrated, ${ }^{366}$ systematic does not mean constant. Monopolistic price discrimination can appear sporadically. To make matters even more difficult, so-called sporadic discrimination seems to be systematic, because it accompanies the transition from one competitive market equilibrium to another. It traces firms' price adjustments to changing conditions of demand or supply. Because such conditions are constantly changing, ${ }^{367}$ firms are constantly adjusting. Sporadic discrimination occurs systematically. So far, the problem appears only to be one of transcribing good theory into good legal doctrine.

360. Posner advocates repeal of the Robinson-Patman Act, followed by judicial expansion of the Sherman Act into the area of price discrimination. See id. at 52-53.

361. See id. at 15-17; supra notes 359-60 and accompanying text.

362. See THE RPA, supra note 10, at 12-15.

363. See id. at 4 . It may also distort competitive relationships and impair efficiency at the customer level. Id. at 3.

364. See supra notes 74-82 and accompanying text; infra notes 412-17 and accompanying text.

365. For example, in a world of imperfect information, the costs may be too high-whether or not anti-price discrimination enforcement is a danger. ANTITRUST LAW, supra note 6, at 62-65.

366. See supra notes 228-35 and accompanying text.

367. THE RPA, supra note 10, at 12-13. 
But when we further investigate the relationship between these two ideas, we find the theory itself inadequate. To describe the deficiency and to uncover the social value judgments submerged in the analysis, we can begin with The RPA's example of a firm with plants in two markets separated by high transportation costs. ${ }^{368}$ In one location, the firm finds that its demand has increased while supply currently cannot. It can raise its price in that location without fear of losing customers, because they have no alternative source of supply. Until supply increases, the firm has temporary monopoly power. Posner offers the price increase as an attractive example of sporadic price discrimination. ${ }^{369} \mathrm{He}$ assumes that discrimination will be transitory, because the higher profits will attract new supply and thus prices will subside. ${ }^{370}$ But unless the old price is now profitmaximizing, it is also possible that an increase in supply will not cause prices to decrease to the earlier level. In short, industry members may agree to make higher profits simply by maintaining subcompetitive industry output at a higher price. ${ }^{371}$ How long should we wait for a price equalization before we call the hypothetical discrimination systematic and the firm conduct monopolistic? Posner's twin texts answer that duration question in two ways. First, they make a statutory response, arguing that the Robinson-Patman Act should be replaced by a Sherman Act monopolization standard. ${ }^{372}$ Thus, they recommend waiting for clear signs of prolonged and significant monopoly power. Although Posner does recognize the possibility of predatory pricing suits for attempts to monopolize, ${ }^{373}$ such acknowledgment should not be mistaken for earlier action. Rather, he makes the curious statement that "systematic or persistent discrimination . . . indeed cannot be explained other than in

368. See id. at 13-14.

369. See id. at 14. Despite his qualification that it is not "technically" price discriminationbecause of the opportunity costs of inadequate production, see id. at $13 \mathrm{n} .15$-Posner seems to offer this scenario as a strong case for price discrimination. Undoubtedly, monopoly profits accrue to the firm. But certain serious harms are assumed away. First, no competitors are injured here since there is a shortage and higher prices rather than overcapacity and lower prices. Second, because all customers are apparently charged the new price, the secondary level effects are limited. Competition between customers at old and new price sales simply does not occur. On the contrary, this territorial discrimination is beneficial for two reasons. It "ration[s] a supply which has suddenly become short in relation to the newly increased demand." Id. at 13. In other words, the increase prices some buyers out of the market. Next, the higher profits attract new output "and prices fall accordingly." Id. But all of this is based on the presumption that new supply will follow. It might not-regardless of current production capacity utilization. A profit-maximizing strategy could call for output level maintenance to protect the higher price. Thus, despite Posner's intimations to the contrary, customer level misallocations would ensue.

370. Id. at 13.

371. For a concise description of perfect profit maximization by a single-price monopolist, see PosNer \& EASTERBROOK, supra note 223, at 4-11.

372. THE RPA, supra note 10, at 49-53.

373. Id. at 22 n.33. 
terms of possession of monopoly power, so that unless we approve the particular instance of monopoly power we can have no kind words for discrimination." 374 Apparently, if we approve of instances of monopoly power-and we are urged to do $\mathrm{so}^{375}$ - then we can also commend price discrimination. Thus, Posner's economics-founded texts appear to approve of some systematic price discrimination-conduct depicted as economically unjustifiable. ${ }^{376}$

Posner's second response to the duration question can be described in terms of barriers to entry-the obstacles faced by potential competitors. It is generally accepted that the greater the obstacles to market entry, the more durable and stronger a firm's market power. ${ }^{377}$ But how does an obstacle become a barrier? According to Posner, only when "a condition . . . imposes higher long-run costs of production on a new entrant than are borne by firms already in the market." 378 Posner contrasts such rare conditions with factors, such as economies of scale, which merely increase the length of time for new entry. ${ }^{379}$ Instead of excluding competitors, these factors simply require them to take more time for organizing and financing. ${ }^{380}$ However, Posner gives two striking examples that implicitly undercut the distinction between exclusion and delay, between barrier and obstacle, that thereby expose an underlying preference for very large and diverse enterprises-for dominant firms, if not monopolies. Such socioeconomic values are unarticulated but encoded in the distinction posed between sporadic and systematic price discrimination, between temporary and persistent market power.

b. Two examples of barriers to entry. The first example of Posner's preference for conglomerate enterprise depicts an industry dominated by large firms, with small rivals who want to expand in order to take advantage of economies of scale. ${ }^{381}$ Posner uses the example to support his argument that since large firms create no entry barriers, but only

374. Id. at 12.

375. ANTITRUST LAw, supra note 6 , at 4.

376. The conduct is economically unjustifiable because of the higher social costs associated with price discrimination and because no net increase in output results. See THE RPA, supra note 10, at 8-10; ANTITRUST LAW, supra note 6, at 64-65.

377. See, e.g., P. AREEDA, supra note 4, at 20-22.

378. ANTITruST LAW, supra note 6, at 59. See also G. STIGLER, Barriers to Entry, Economies of Scale, and Firm Size, in THE ORGanization OF INDUSTRY 67 (1968).

379. ANTITRUST LAW, supra note 6, at 59.

Other LEA scholars disagree with Posner's conclusion that barriers are unusual. Philip Areeda believes that they are not so unusual. See P. AREEDA, supra note 4, at 22. Robert Bork, on the other hand, asserts that, for proper antitrust purposes, there are no barriers to entry. See R. BoRK, supra note 1, at 310. Yet all three agree that the Robinson-Patman Act should not enter into the calculus.

380. ANTITRUSt Law, supra note 6, at 57-59.

381. Id. at 92. 
delays to expansion, we need not and should not break them up. ${ }^{382}$

Posner examines costs, other than exclusionary practices, ${ }^{383}$ traditionally viewed as barriers to entry. In each instance, he characterizes them as obstacles rather than barriers. Posner begins by arguing against the materiality of nonrecurring costs of entry. 384 Specifically, he acknowledges Williamson's position that the cost of capital includes a nonrecurring element: 385 "That cost includes a premium for risk, and if new ventures are characteristically riskier than established businesses the existing firms in the market may be able to raise money at lower cost than a new entrant." 386 That seems to make sense. Posner contends, however, that Williamson overlooks the fact that many potential entrants are diversified firms. ${ }^{387}$ Such firms can raise money more cheaply because they resemble a diversified stock portfolio designed to spread risk by mimicking the market. No more or less risky than an efficient capital market, ${ }^{388}$ conglomerates are thus efficient capital-raisers and should be welcomed, indeed preferred.

Posner's scenario raises an important issue: What becomes of all the firms, particularly small- and medium-sized ones, that do not resemble that model of diversification? The implication is that such enterprises are inefficient and for that reason alone should bear the market consequences. But should such efficiencies, even if established, provide an unbalanced rationale for such a radical shift from traditional social policy judgments associated with antitrust? Or should we balance such firms' efficiencies with their economic inefficiencies ${ }^{389}$ and other social costs? To suggest that there are no nonrecurring costs of entry because we can encourage large conglomerates to grow and to diversify is to attack one

382. Id. at $92-95$.

383. See infra notes $391-406$ and accompanying text.

384. See ANTITRUST LAw, supra note 6, at 92-93.

385. See Williamson, Dominant Firms and the Monopoly Problem: Market Failure Considerations, 85 HARV. L. REV. 1512 (1972).

386. ANTITRUST LAW, supra note 6, at 93.

387. Id.

388. Indeed, current LEA orthodoxy-efficient capital markets theory-teaches that we can do no better than the market. See R. POSNER \& K. SCOTT, ECONOMICS OF CORPORATION LAW AND SECURITIES REgULATION 155-85 (1980).

389. See, e.g., F. SCherer, A. Beckenstein, E. KAUfer \& R. MURPhy, The Economics of MUlti-Plant OPERATION-AN INTERnational COMParisons Study 237-354 (1975) (large mergers result in minimal efficiency benefits); FEDERAL TRADE COMMISSION STAFF REPORT, CONglomerate Merger Performance: An Empirical ANalysis of Nine Corporations 33-60 (1972) (sizable mergers followed by insignificant operational changes directed at improving efficiency). 
problem by sacrificing valued solutions to another. ${ }^{390}$ That kind of balancing is more appropriately performed as an explicit antitrust policymaking enterprise, not a neutral economic analysis of entry barriers.

The second example of Posner's preference for conglomerate enterprise focuses on exclusionary practices. ${ }^{391} \mathrm{He}$ argues that, aside from economies of scale, there are only three reasons for higher costs: valid patents, more efficient management, or exclusionary practices. ${ }^{392}$ The first two cost differences are legitimate, while exclusionary practices, such as predatory or discriminatory prices, ${ }^{393}$ can be deterred without dissolution of dominant firms. ${ }^{394}$ Standard Oil provides exemplary facts for Posner's view of the exclusionary value of predatory pricing. ${ }^{395}$ Both the traditional legal and the common understanding of the success of the Standard Oil Trust focus on the firm's exclusionary practices, particularly its territorial price discrimination. ${ }^{396}$ But a 1958 study of the Standard Oil records has strongly influenced LEA scholars to discount the extent to which dominant firms can benefit from predatory tactics. ${ }^{397}$ In the course of a re-invigorated argument for effective predatory pricing, Posner points to a purchaser world of local markets with less-than-perfect information, ${ }^{398}$ of "free-riders" who buy from the predatory pricer and who count on others to buy from higher-priced rivals to keep them in business, ${ }^{399}$ and to a seller world where strategic predation and litigation settlement may be least-cost alternatives. ${ }^{400}$ Posner concludes that predatory pricing "cannot be dismissed as inevitably an irrational practice." 401

In arriving at this conclusion, Posner does not assume that the predator has superior access to the capital market and can finance the campaign more cheaply than small or potential rivals. ${ }^{402}$ Rather, the "genuinely exclusionary practice" of predatory pricing "at most is likely

390. See Blake, Conglomerate Mergers and the Antitrust Laws, 73 COLUM. L. REv. 555, 570 (1973) (preferential access to capital resulting from conglomerate mergers poses a strong probability of injury to competition).

391. ANTITRUST LAW, supra note 6, at 92.

392. Id. at $91-93$.

393. Id. at $184-92$.

394. Id. at 93.

395. Id. at 186-87.

396. See, e.g., id. at $184-87$.

397. McGee, Predatory Price Cutting: The Standard Oil (N.J.) Case, 1 J. L. \& Econ. 137, 16869 (1958), cited in ANTITRUST LAW, supra note 6, at 185 n.29.

398. ANTITRUST LAW, supra note 6 , at $184-85$.

399. Id. at 185 .

400. Id. at $184-86$.

401. Id. at 186.

402. Id. The example does assume committed resources and thus a rival's loss of salvage value upon shift to another use. Id. 
to delay, rather than prevent, the entry of new competitors." ${ }^{403}$ But how does a practice, first labeled genuinely exclusionary, later only delay entry? This dissonance is accounted for by Posner's consistent market vision of monopolistic dominant firms. Posner asserts that predatory pricing is a rational economic strategy when the predator can anticipate that monopoly profits will justify current losses. ${ }^{404}$ But future monopoly profits are an insufficient incentive to prey. ${ }^{405}$ Successful territorial price discrimination requires current recoupment from locations devoid of rivalry. Thus, such a strategy would succeed against local or regional businesses. But a firm planning to enter all markets of the dominant firm would not be deterred. ${ }^{406}$ Predatory pricing merely postpones large-scale entry; it excludes only small or local potential competitors. Posner's rhetorical shift from exclusion to delay is premised on a political economy of large scale enterprise.

As in the first example's analysis of the capital costs of increasing scale, Posner concludes that the only effect of price discrimination is a delay attributable to the financing and organizing of an increase in the scale of new entry. ${ }^{407}$ Because this is not a barrier but only an obstacle to entry, Posner argues, we should not be concerned with such behavior. Posner has previously asserted that conglomerate dissolution is not justifiable. ${ }^{408}$ Monopolistic price discrimination, however, appears to be something more clearly objectionable. Posner has already adverted to the Sherman Act as the appropriate mechanism for dealing with predatory conduct. ${ }^{409}$ Here, he offers the LEA framework for that statutory resolution: We should examine the relation between cost and price to measure the monopolistic character of the behavior. If price is above cost, then the conduct does not offend economic values-the most efficient firm wins. ${ }^{410}$

However, if the only firm that can compete is large-scale, if expanding to such size requires extensive capitalization, and if only large diversified firms do not face a higher nonrecurring capital cost of entry, then several significant implications result. First, all nonconglomerate firms are excluded from the market by the cost of across-the-board entry-by the predation. Thus, it turns out that the Posnerian predator

403. Id. at 186 .

404. Id. at 184 .

405. Id. at $185-86$.

406. Id. at $186-87$.

407. Id. at 187; see also id. at $92-95$ (stating that the nonrecurring costs of entry are not barriers to entry and that large-scale production will be required to take advantage of economies of scalc). 408. See id. at 79.

409. See id. at $52-53$.

410. See id. at 193. 
does enjoy superior access to capital markets. Only other large diversified firms share such superior access to capital markets and the advantage of lower capital costs. As a result, both fixed and variable costs can remain below those of smaller-scale rivals. In the LEA's terminology of current antitrust doctrine, its "fighting" price need not dip below those of smaller-scale rivals. In fact, its "fighting" price need not dip below its variable cost; it can successfully exclude local and regional competitors without offending economic conceptions of predatory pricing. ${ }^{411} \mathrm{We}$ are left with the Hobson's Choice between monopolistic dominant firm markets on the one hand and conglomerate oligopolistic markets on the other. ${ }^{412}$

c. An old contradiction in new clothes. The two preceding examples are so striking because in each instance, the arguments begin by announcing the absence of entry barriers-a necessary condition for competition and a value crucial to its ideological appeal. But each concludes with a vision of large-firm dominance and conglomerate rivalry. This shift is the consequence of Posner's normative point of departure; efficiency, not competition, is his LEA origin. 413 In both examples, Posner proceeds from efficiency, not competition, to argue for the benefit of this conglomerate vision. What both narratives demonstrate is the LEA's normative opposition to forms of commercial enterprise other than large conglomerate firms. All small- or medium-sized business, all local or regional companies, and even some large firms, simply do not fit into Posner's logic of efficiency. A vision that promotes such large-scale dominant firms cannot tolerate the idea of competition as a mechanism for dispersing economic power. Nor can it permit antitrust law interpretation that serves extra-efficiency purposes. Finally, this antitrust vision belies Posner's own assertion that his basic antitrust concern is with monopoly. ${ }^{414}$

In essence, Posner's twin texts fashion old clothes for a new emperor. The systematic/sporadic matrix for evaluating price discrimination is incoherent and thus has no operational utility. But it has ideological value. It seeks to derive the legitimacy of its vision of monopolistic markets from the ideology of competition and dynamic free mar-

411. See generally ANTITRUST LAw, supra note 6, at 191-94; Areeda \& Turner, Predatory Pricing and Related Practices Under Section 2 of the Sherman Act, 88 HARV. L. REV. 697 (1975) (proposes price-to-variable cost standard for predatory pricing doctrine).

412. Posner's interest in denying the possibility of oligopoly takes on a different hue. See ANTITRUST LAW, supra note 6, at 42-46 (interdependence theory of oligopoly pricing).

413. See id. at 4 (previewing the author's later argument that efficiency should be the only goal of antitrust law).

414. See id. at 3. 
kets. ${ }^{415}$ In general, Posner's writings depend upon the attractiveness of the competitive ideology, yet limit the competitive ideal's role to ideology. Here, he justifies the desired status quo of conglomerate markets with an argument derived from a competitive model of change-describing systematic price discrimination as merely a residue of sporadic discrimination. Potential entrants encounter only obstacles, never actionable barriers. ${ }^{416}$ Ultimately, the ideological value of competition is its implication of unseating persistent market power. Posner's unworldly view of no entry barriers idealizes potential competition in order to perfect its ideological value. ${ }^{417}$ In short, the dynamic of potential competition supports an argument to protect current market poiver from antitrust intervention.

These LEA parables of conglomerate firms encounter a fundamental ideological contradiction in antitrust doctrine. They seek to resolve the conflicting demands of competition and private property, of process and protection. The common strategy is resolution by merger: Only proper process-competition-should create and destroy property. Proper process demands protection of the status quo. For the Robinson-Patman Act's congressional proponents, that waning status quo was a system of small, independent businesses symbolized by the $\mathrm{Ma}$ and $\mathrm{Pa}$ Grocery. For the LEA, status quo means the prevailing structure of market power, symbolized by the idea of efficiency. The LEA defines competition as the proper origin whose structure and process always remain properwhatever their character. This striking difference is founded in an LEA corollary of the foregoing logic that only competition properly allocates property: Only competition should create or destroy monopoly. This extension of a common logic makes clear that the salient distinction between the two encounters with the contradiction emerges from the relationship between the LEA's ideas of monopoly and property. Both ideas derive from a normative preference for free markets, from the LEA's idealized image of unfettered competition as the only proper origin-the only legitimate source for entitlement, whether that entitlement is termed property or monopoly.

Despite advancing a political economy of firm conglomeration and large-scale enterprise, the Law and Economics Approach now carries the ideological banner of competition. At the same time, the Robinson-Patman Act has come to symbolize values incompatible with proper compe-

415. Cf. Ingber, The Marketplace of Ideas: A Legitimizing Myth, 1984 DuKE L.J. 1 (discusses the ideological value of the market idea).

416. Posner does note an exception for efficiency barriers-but these are legitimate.

417. But see ANTITRUST LAw, supra note 6, at 122-24 (taking a realistic and pragmatic look at the potential competition doctrine and deciding that it is unworkable). 
tition, although it is emblematic of the Jeffersonian vision of individual entrepreneuralism. How is it that the Act has come to be considered anticompetitive, while the LEA represents antitrust? What is proper competition - this transformation of perfect competition? Ultimately, it is a regime founded not in the complex of values that constitute the traditional ideal of competition, but in the norm of efficiency. How then is the LEA associated with competition? It draws upon competition's ideological attraction, but redefines its functional characteristics. A residual strain of sociopolitical legitimacy runs through the LEA's efficiencybased revision of competition. What connections are drawn between the ideas of efficiency and competition to elicit this overwhelming perception of serving competition? The last section investigates Posner's version of the proper relationships among monopoly, competition, and efficiency. This transformation neither escapes nor reconciles the basic antitrust contradiction. An efficiency logic only reproduces the ideological dilemma.

\section{Price Discrimination and Posner's Marginal Logic of Efficiency.}

The LEA claims that firms, free to compete, move markets toward efficiency. This simple proposition raises two complex questions. First, what relationships are posited among competition, monopoly, and efficiency? Second, what is meant by "efficiency" and in what sense is the Robinson-Patman Act inefficient?

1. Efficiency as Teleology. The last section's exploration of barriers to entry questioned Posner's portrayal of competition as the source and justification for sustained market power. Posner's dynamic is not a new one; traditional antitrust doctrine depicts the dilemma of monopoly power in much the same way. Despite the recognition that powerful firms can not only injure both competitors and trading partners but also result in lowver output and higher prices, the ideology of competition has something to say in favor of monopoly power: Its possession can reflect an attractive norm of just reward. In the familiar words of Learned Hand's Alcoa opinion, ${ }^{418}$ "Finis opus coronat": The end crowns the work. Monopoly perfects individual competitive success.

To mediate monopoly's contradiction of public injury and private property, traditional antitrust doctrine has attempted to distinguish between good and bad monopolies. ${ }^{419}$ Conduct such as predatory pricing

418. United States v. Aluminum Co. of America, 148 F.2d 416, 430 (2d Cir. 1945).

419. See, e.g., United States v. Grinnell, 384 U.S. 563, 570-71 (1966) (proof of violation of Sherman Act section 2 requires a showing of monopoly power and willful acquisition or maintenance of that power); United States v. Griffith, 334 U.S. 100, 107 (1948) ("the use of monopoly power, how- 
that suggests overreaching can condemn a firm with monopoly power. Otherwise, the Sherman Act's rule of reason standard does not demand a return to the efficiencies of competition. ${ }^{420}$ Yet Congress expressed its concern over the public injury resulting from market power allowed by Standard Oil's rule of reason in its passage of the Clayton and RobinsonPatman Acts to protect individual competitors from the perceived market power of large firms and nationwide chain stores. The sense was then and still is today that competitive markets push prices down to costs and minimize costs as well. Further, the ideology of competition as the traditional guide to antitrust enforcement has represented a five-dimensional complex of social and political values-not only economic efficiency, but also Jeffersonian entrepreneurialism, fair competition, equitable distribution, and a common law tradition. ${ }^{421}$

But the LEA has reversed the traditional doctrinal connections between competition and sociopolitical values. No longer is efficiency depicted as simply one among many reasons to prefer competitive markets. Rather, competition is evaluated according to how well it serves efficiency:

[T]here is no justification for carrying enforcement into areas where competition is less efficient than monopoly because the costs of monopoly pricing are outweighed by the economies of centralizing production in one or a very few firms. Nor is there justification for using the antitrust laws to attain goals unrelated or antithetical to efficiency, such as promoting a society of small tradespeople. ${ }^{422}$

Many students of antitrust have found this radical reordering attractive for two sets of reasons. First, the reversal continues to serve two significant values traditionally associated with the ideology of competition. Accumulation of dollars or market power retains a meritocratic aura; the LEA assumes that competitive success is earned. Moreover, free marketeering serves as the proxy for personal autonomy. ${ }^{423}$ In short, the reordering claims both traditional antitrust and libertarian ancestry. Second, it answers a strongly felt institutional need. An efficiency-based methodology purports to provide legal argument with a new formalism, a deductive system of universally acceptable premises and unavoidable conclusions. It occupies the vacuum created by legal realism's explosion

ever lawfully acquired, to foreclose competition, to gain a competitive advantage, or to destroy a competitor, is unlawful").

420. See United States v. Standard Oil of New Jersey, 221 U.S. 1, 59-60 (1911) (setting forth the rule of reason); United States v. Aluminum Co. of America, 148 F.2d 416, 430 (2d Cir. 1945) (monopoly attained by "superior skill, foresight and industry" is lawful).

421. See, e.g., supra note 13.

422. ANTITRUST LAw, supra note 6, at 4 .

423. See generally Posner, supra note 19. 
of legal formalism's claim to airtight doctrinal analysis. It claims to be the new right-answer machine. ${ }^{424}$

In addition to serving an individualistic ethic of just reward and providing deductive certainty for legal decisionmakers, the LEA offers something else, something that can be called a new metaphysics. This teleology of efficiency purports to resolve traditional antitrust doctrine's dilemma of monopoly -it denies the ideological tension between ideas of competition and monopoly by transforming their relationship. Their connection is not direct, but rather is mediated by the overarching value of efficiency.

Unlike the Robinson-Patman Act's either/or metaphysics which accepts the traditional vision of competition in opposition to monopoly, the LEA teleology of efficiency denies the tension by asserting that the two ideas no longer oppose one another. Rather, they both serve the sovereign value of efficiency. Unlike the doctrinal history of that tensionpendular swings between the extremes-the logic of this efficiency-based argument comprehends both property and process, both change and status quo, both competition and monopoly. Thus the LEA not only promises to dissolve the basic tension, but also claims thereby to settle antitrust doctrine.

However, that normative direction is uncontroversial only after others have been pushed to the margins of proper antitrust argument and excluded. This section analyzes what then is left at the center-the logic of efficiency. In particular, a demonstration of Posner's shifting notions of "efficiency" indicates the incoherence and limited utility of efficiency and demonstrates the contribution of price discrimination to the logic of efficiency.

Posner's untraditional preference for large diverse firms is founded in efficiency. According to Posner, dominant firms should be praised, not buried, because their power justly derives from two kinds of success. First, their costs are lower because of economies of scale. Thus, productive efficiencies and marginal costs underwrite their market power. Second, their positions are maintained against the constant threat of rivalry and disciplined by the inescapable specter of potential competition. They succeed simply because they do a better job of supplying consumer

424. See Leff, Economic Analysis of Law: Some Realism About Nominalism, 60 VA. L. REv. 451,459 (1974) ("the move to economic analysis . . . seems an attempt to get over, or at least get by, the complexity thrust upon us by the Realists") (reviewing R. POSNER, ECONOMIC ANALYSIS OF LAw (1973)); see also Posner, The Present Situation in Legal Scholarship, 90 YALE L.J. 1113, 1115 (1981) (discussing the economic approach to law); Sullivan, Book Review, 75 Colum. L. REv. 1214, 1222 (1975) (economics provides "an analytical system" for resolving antitrust issues) (reviewing $M$. Handler, H. Blake, R. Pitofsky \& H. Goldschmid, Trade Reg. (1974)). 
desires and satisfying buyers' marginal utilities. Thus, allocative efficiency is served. Posner characterizes monopoly power as not only meritorious, but also perishable-in short, nothing to worry about.

The LEA argues that perfect price discrimination serves both forms of efficiency because a price-discriminating monopolist is given an incentive to increase output to the level of a competitive market-where marginal cost equals price. The increased production allows the large-scale producer to take better advantage of economies of scale; that is, to produce more efficiently. Price discrimination also enables the monopolist to match his price to the item's value-its marginal utility-to each buyer. ${ }^{425}$ In that way, a price-discriminating monopolist can approach allocative efficiency more closely than can a single-price monopolist. Thus, price discrimination is also nothing to worry about. Rather, the economic logic of marginality demonstrates its double efficiency. ${ }^{426}$

The prescriptive appeal of these propositions gives them power. Monopoly is described as an efficient though temporary state, as a necessary interequilibrium transition between conditions of competition. If such power is ever more than temporary, then its possessor must be better in some significant way. The LEA's teleology allows only one form of "better" and that is "more efficient." 427

2. Efficiency as Epistemology. There are many ways in which one state of affairs can be "better" than another. An antitrust rule interpretation can seek to encourage fair competition or can promote a more equitable distribution of wealth. Current LEA orthodoxy repudiates such forms of "better;" rather, it defines "better" as "more efficient." As it turns out, the notion of efficiency has many faces, not only among different commentators, but also within the work of particular commentators. This subsection continues the focus on Posner's two antitrust monographs in order to offer a structural critique, not an exhaustive explanation, of efficiency. ${ }^{428}$

Apparently, economists mean one thing and LEA scholars mean another when they refer to economic efficiency. 429 In his Antitrust Law, The RPA, and other writings, Posner sometimes means productive effi-

425. P. Samuelson, Economics 439 n.9 (10th ed. 1976).

426. For a related but different logic of efficiency, see infra notes $478-87$ and accompanying text.

427. See ANTitrust Law, supra note 6, at 4 (there is no justification for carrying enforcement of antitrust laws into areas where monopoly is more efficient than competition). Note that Posner's analysis requires a denial of the oligopoly problem. See, e.g., P. AREEDA, supra note 4, at 270-85 (discussing the oligopoly problem).

428. See supra note 19.

429. See Dworkin, Is Wealth a Value?, 9 J. LEGAL STuD. 191, 191 (1980) (criticizing normative economic analysis of law). 
ciency and other times means allocative efficiency. This subsection first examines Posner's productive efficiency analysis and finds it an inadequate standard for price discrimination doctrine. Next, his wealth maximization form of allocative efficiency is found economically incoherent. The consequence of this double failure is an efficiency nightmare whose motivation is clear. Price-discriminating monopolists are portrayed as wealth-maximizers-more efficient-and thus as better.

a. Productive efficiency. Economists think of productive efficiency as an "engineering" concept-the production of the most that an economy, industry, or firm can produce with the resources available. 430 The economic idea is clearly cost-related-making the most from the least. The first reference to productive efficiency in The RPA illustrates Posner's strongest objection to price discrimination-the impairment of efficiency at the customer level. ${ }^{431} \mathrm{He}$ gives an example involving two customers located at different distances from a seller's plant. The nearer customer ought to pay a lower price for the seller's goods because of the seller's lower transportation costs. If both customers pay the same price, then the seller is engaging in economic price discrimination-prices are not in the same proportion to the marginal costs of each sale. ${ }^{432}$ This scenario is consistent with an earlier stated preference for centralized production, even when accompanied by monopoly pricing. ${ }^{433}$ While the two references to economizing buyers and sellers strike the common note of productive efficiency, they produce a false harmony. If both Posner's centralized seller and proximate buyer are judged according to how well their conduct serves the value of productive efficiency, we can quickly understand the incoherence. What if Posner's economizing seller exercises market power to price discriminate against his economizing buyer? Presumably the seller's power derives from efficiency advantages over its actual and potential rivals. Should we do anything to assure that this seller does not benefit from the buyer's productive efficiency? If not, we produce a disincentive to the buyer's productive efficiency. If productive efficiency is the guiding principle, whose efficiency should guide us? In this instance, any choice, including non-intervention, can be said both to

430. See R. Lipsey \& P. Steiner, Economics 172-73 (3d ed. 1972).

431. THE RPA, supra note 10, at 3-4; see also ANTITRUST LAw, supra note 6, at 4 (the goal of antitrust law should be to promote efficiency).

432. THE RPA, supra note 10 , at 3 . Posner here echoes a concern already institutionalized in the Act's cost-justification defense. Still, the Court has affirmed a narrow FTC interpretation of that defense. See United States v. Borden Co., 370 U.S. 460, 467-69 (1962) (in proving cost justification, defendant must show that price differences reflect only a "due allowance" for actual cost differences between distinct classes of customers).

433. ANTITRUST LAW, supra note 6, at 4. 
favor and to disfavor efficiency. Although The RPA declares buyer market disruption a problem, it nonetheless urges statutory repeal and thus no intervention. ${ }^{434}$ Antitrust Law counsels against any antitrust proscription of such conduct. ${ }^{435}$ As always, nonintervention favors the status quo. The large-scale seller's greater bargaining poiver would capture the benefit of the buyer's productive efficiency. To the extent that the Robinson-Patman Act provides the buyer with a cause of action to recapture the benefit of its locational advantage, productive efficiency is served.436

But we can also identify instances in which the Act supports productive inefficiency. For example, a narrow interpretation of its costjustification defense shifts the benefit of productive efficiencies away from the efficient producer. ${ }^{437}$ Although statutory construction has sometimes had such consequences, there is nothing in the Act's language or history that compels this sort of favoritism. ${ }^{438}$ Rather, court doctrine has plotted an uneven course of benefit allocation. Such movements represent the courts' unsuccessful attempts to resolve the basic antitrust contradiction embodied in traditional legal analysis. But Posner's productive efficiency approach offers no better guidance for making consistent judgments about price discrimination.

b. Allocative efficiency. This part first summarizes the two most common forms of allocative efficiency-Pareto optimality and wealth maximization. It then explains Posner's preference for wealth maximization, in order to demonstrate first that wealth is a dubious measure of social value, and second that Posner's choice of wealth fails to serve his purpose of defusing social objections to monopoly and price discrimination.

Pareto optimality, wealth maximization, and other forms of allocative efficiency are ideas whose application to real-world decisionmaking depend upon the fulfillment of certain conditions. That is, these ideas

434. THE RPA, supra note 10, at 52 (arguing that the Robinson-Patman Act should be repealed, thus limiting antitrust scrutiny of price discrimination to the Sherman Act).

435. AnTITRust Law, supra note 6, at 65. In Antitrust, Posner and Easterbrook seek to solve the problem by physically separating them; primary line is treated under Sherman Act section two predatory pricing, while secondary line appears in a separate chapter. Their problematic relationship need not be confronted. See POSNER \& EASTERBOOK, supra note 223, at 680-714, 943-54.

436. See, e.g., Corn Products Refining Co. v. FTC, 324 U.S. 726, 733 (1945) (net receipts test applied to invalidate basing-point price system); Cement Institute, 37 FTC 87, 256-57 (1943) (invalidating discriminatory basing-point price system). Cf. P. AREEDA, supra note 4, at 1095-97 (discussing basing-point pricing).

437. See United States v. Borden Co., 370 U.S. 460, $469-70$ (1962) (rejecting cost justification defense involving certain kinds of volume discounts).

438. Further, productive efficiency need not reside in large firms. See, e.g., Scherer, Book Review, 86 YALE L.J. 974, 986-88 (1977) (arguing that the goals of efficiency and preservation of small business are not contradictory). 
make certain assumptions about some variables in order to describe relations among other variables. The logic and thus the value of models depends upon the control of certain variables, the constancy of certain conditions. It is not surprising, then, that there is a consensus among economists and LEA adherents that the real world cannot meet the efficiency model's requirements. Thus, the allocative efficiency consequences of any antitrust policy are not determinable. Allocative efficiency simply does not provide a workable standard for social policymaking. ${ }^{439}$ Rather, second best solutions-policies that serve values resembling allocative efficiency-ought to be pursued. ${ }^{440}$ Nevertheless, Posner comments that "it seems wise as a practical matter to ignore this consideration." 441 As the following analysis demonstrates, even Posner's "practical" suggestion to ignore this insoluble problem cannot save his efficiency logics.

When antitrust texts refer to allocative efficiency, they usually mean Pareto superiority or wealth maximization. ${ }^{442}$ While both forms describe standards for comparing allocations of society's resources, each can recommend a significantly different state of affairs as "better." To appreciate their membership in a family of allocative efficiencies, consider each idea as having two parts-a criterion of value and a method for comparison. Here, either utility or wealth represents the social value criterion, while Pareto superiority or maximization provides the method for comparing allocations.

Although utility and wealth do not exhaust the universe of social values to be served, economists generally concern themselves with utility, while LEA practitioners focus on wealth. ${ }^{443}$ Choosing the former commits the policymaker to assess subjective utilities-personal preferences. The potential psychological and material dimensions of subjective utility

439. For an in-depth analysis, see F. SCHERER, supra note 13, at 19-26 (discussing objections to allocative efficiency theory); L. Sullivan, supra note 14, at 3-5 (discussing the "second best" objections to allocative efficiency theory); Markovits, supra note 215, at 953-54 (arguing that, based on the theory of second best, allocative efficiency does not provide an effective rule for policy-making).

440. See Lipsey \& Lancaster, The General Theory of Second Best, 24 Rev. Econ. STud. 11 (1956); F. SCHERER, supra note 13, at 25-27 (arguing that procompetitive policies should be pursued whenever possible); see also Leff, supra note 424, at 476 ("If a state of affairs is the product of $n$ variables, and you have knowledge of or control over less than $n$ variables, if you think you know what's going to happen when you vary 'your' variables, you're a booby.').

441. POSNER \& EASTERBROOK, supra note 223, at 117.

442. See e.g., P. AREedA, supra note 4, at 8 (Pareto efficiency); POSNER \& EASTERBRook, supra note 223, at 9-10 (wealth maximization); L. SullivaN, supra note 14, at 2-7 (allocative efficiency).

443. See Dworkin, Why Efficiency?, 8 HofsTRA L. REV. 563, 563-73 (1980). Of course many values can be maximized or otherwise privileged-freedom of association, affirmative action, and workplace democracy are three examples. For yet another form, see Sager, Pareto Superiority, Consent, and Justice, 8 HoFSTRA L. REV. 913, 915 n.4 (1980) (justice as aggregatable norm-justicemaximizing). 
undoubtedly are countless. Although such preferences are not quantifiable for most empirical purposes, ${ }^{444}$ economists sometimes rank them on an evaluative scale called "utils." 445

The LEA's choice of wealth as the proxy for utility satisfies the empirical imperative of measurability because market activity offers ready data for making wealth calculations. Moreover, such wealth measurement purports to offer policymakers a correct picture of the world. ${ }^{446}$ Both the strength and the weakness of this assertion is the implication that we need think only in terms of markets. Its strength lies in the normative predicate that only free markets allow for free exchange. Free markets nominate wealth as the sole measure of freely expressed preference, as the only proper cumulator of society's desires. Posner argues that the "only kind of preference that counts in a system of wealth maximization is . . . one that is backed up by money." 447

Despite wealth's measurability and libertarian hue, its normative appeal is weakened by several problematic equations. First, this scheme equates an inability to pay with an unwillingness to pay. Second, it identifies dollars and market transactions as the exclusive dimensions of preference, so that political preferences and other extra-market desires are not counted. Third, the claim that market transactions are entirely free is unconvincing. 448 The LEA's social and political focus-wealth-turns out to be a dubious proxy for utility.

Whether wealth or utility comprises the privileged social value, how should it be served? The second part of the allocative efficiency concept prescribes the ways in which states of affairs are to be compared. If the criterion is wealth, one state is preferable to another only when wealth increases; if utility, only when subjective utility improves. Again, traditional economists and LEA practitioners tend to make different judgments regarding improvement. The former usually adopt the standard

444. See Kornhauser, supra note 298, at 598-99 (wealth maximization is an ordinal variable).

445. See, e.g., P. SAmuelson, Economics 417-22 (7th ed. 1967) (discussing the theory and formulaic derivation of equal marginal utility units, "utils"). For an argument seeking to distinguish between utilitarians and economists, see Posner, supra note 19, at 111-35 (arguing for use of economic analysis of wealth maximization as preferable moral system to utilitarianism or Kantianism).

446. See Posner, supra note 19, at 131-35.

447. See id. at 119; but see Kelman, Choice and Utility, 1979 Wis. L. REv. 769, 778-82 (arguing that whether or not a transaction is beneficial cannot actually be measured solely by choice of consumer at time of transaction, but must also take into account his or her subsequent use); P. SAMUELSON, ECONOMICS 419, 419 n.3 (7th ed. 1967) (suggesting that majority of present day theorists measure utility behavioristically, and in "greater than" or "less than" terms rather than numerically).

448. See Kelman, supra note 447 , at 787-97 (arguing that neoclassical economists have failed to see the readily-discernible split between "choices" and "preferences" when evaluating the benefits of a "free choice" market). 
devised by Wilfredo Pareto 449 that a policymaker should effect change only if that change benefits someone yet hurts no one. ${ }^{450}$ If there are no superior states-if even one person would be worse off after any change-then the status quo is Pareto optimal. LEA advocates apply a significantly different calculus-a policymaker should judge change based on net effect, on winnings outnumbering losses. Combining a preference for wealth with one for net effect, called maximization, Posner would invoke change if the new state of affairs generates enough additional wealth to winners that they can, though they need not, compensate losers. Thus, for example, if by price discriminating a monopolist gains more wealth than consumers lose, the LEA would approve of the conduct. This notion of wealth maximization characterizes the LEA calls for consumer welfare and for allocative efficiency. ${ }^{451}$

c. Posner's efficiency logics. What does Posner mean by efficiency? The RPA and Antitrust Law both argue that monopoly in general and price discrimination in particular are "objectionable on strict economic-efficiency grounds." 452 That appears to be a reference to Pareto superiority in utility terms. Posner then moves away from a "strict" economic standard, expressing concern regarding conduct "inefficient or anticompetitive in some legitimate economic sense." 453 Here, an ambiguous reference increases the ways in which conduct can be inefficient. In Posner's later journal articles ${ }^{454}$ and in the Posner and Easterbrook Antitrust textbook, efficiency signifies wealth maximization. ${ }^{455}$ Yet the introduction to Antitrust Law announces that "the goal of antitrust law should be to promote efficiency in the economic sense." 456 Is that different from strict economic sense? From some legitimate eco-

449. See supra note 252. For example, if the value remains wealth but the standard is Pareto superiority, any wealth transfer in the form of a monopoly price labels a higher-than-competitive price as Pareto inferior, because at least one consumer must pay more and thereby gives up more wealth than she would at a competitive price.

450. Consider the following example: $A, B$, and $C$ each has $\$ 5 ; D$ has $\$ 100$. Increasing the $\$ 5$ trio's wealth to $\$ 50$ each while decreasing $D$ 's to $\$ 99$ is not Pareto superior; but doubling $D$ 's wealth to $\$ 200$ while leaving the trio at $\$ 5$ is superior.

451. See Posner, supra note 19, at 128-32 (measuring social cost against social benefit to determine justifiability). Compare THE RPA, supra note 10, at 7, 27 (traditional view of monopoly problem as lowering productive efficiency in segments of business community prohibited some forms of price discrimination that were economically efficient), with R. POSNER, ECONOMlC ANALYSIS OF LAW $4-5$ (1974) (utilitarian). But see R. BORK, supra note 1, at 91 (efficiency means productive efficiency-business success).

452. THE RPA, supra note 10, at 7; see id., at 7-10; ANT1TRUST LAW, supra note 6, at 11-15.

453. THE RPA, supra note 10, at 27 (emphasis added).

454. See, e.g., Posner, supra note 19, at 119 (arguing for moral system based on economic evaluation of wealth maximization).

455. POSNER \& EASTERBROOK, supra note 223, at 9-10.

456. ANTITRUST LAW, supra note 6 , at 4. 
nomic sense? Other commentators have noted a particular direction in Posner's shifting senses of efficiency -away from Pareto optimality and toward wealth maximization. ${ }^{457}$ In his two antitrust monographs, such movements, as well as apparent calls to productive efficiency, trace an unstable goal for antitrust policymaking. 458

Nonetheless, Posner claims that antitrust policy loyal to the value of efficiency can rescue antitrust doctrine from its current state of incoherence. More specifically, for Posner it is efficiency that solves the central antitrust problem of monopoly. 459 The implication, of course, is that the antitrust problem with monopoly is inefficiency. Accordingly, other consequences of monopoly -in particular, the "social objection" to distributive consequences-are political concerns better left outside the antitrust laws. Yet Posner transgresses his own instruction to segregate antitrust policy and efficiency concerns from politics and distributive concerns. He cannot honor this LEA commitment to maintain the barrier between distribution and allocation, between the politics and economics of political economy, for two reasons. ${ }^{460}$ First the discipline of economics defines allocative efficiency, whether Pareto efficiency or wealth maximization, as dependent upon income and wealth distribution. ${ }^{461}$ That is, when income or wealth distribution changes, Posner recognizes that the pattern of demands can change. If they do, then resources must be reallocated. The status quo by definition is no longer efficient. And because policies generally have distributive effects, ${ }^{462}$ their impact on efficiency must be accounted for. Second, the shift from strict economic efficiency to wealth maximization has an undesirable ethical byproduct: It permits losers so long as cumulative winnings are greater than cumulative losses. Posner must thus confront controversial distributive consequences. ${ }^{463}$

457. See, e.g., Horwitz, supra note 82; Coleman, Efficiency, Utility, and Wealth Maximization, 8 HoFstra L. REV. 509 (1980).

458. Bork avoids all of Posner's difficulties by first defining productive efficiency as business success, then by defining his references to efficiency as calls to productive efficiency. See R. BoRk, supra note 1, at 91, 104-06. Thus, the only proper service of Bork's efficiency is free-marketeeringthat is, no antitrust intervention.

459. See ANTITRUST LAW, supra note 6, at 4 (outlining the author's plan to argue that efficiency is the only goal of antitrust law).

460. For a brief historical analysis of the division between distributive and allocative concerns, see Horwitz, supra note 82.

461. R. POSNER supra note 451, at 4-5; Kornhauser, supra note 298, at 592-97.

462. Indeed, Ronald Coase argues that changing substantive rules has only distributive effects. See Coase, The Problem of Social Costs, 3 J. L. \& Econ. 1 (1960) (assuming no transaction costs, parties will bargain to most efficient solution). For a critique, see Kelman, Consumption Theory, Production Theory, and Ideology in the Coase Theorem, 52 S. CAL. L. REv. 669 (1969).

463. That is, he feels compelled to defuse the "normative economic significance" of monopoly profits. POSNER \& EASTERBROOK, supra note 223, at 10. 
Two attempts at minimizing distributive consequences merit attention because each desires, yet fails, to defuse the ethical problem of monopoly profits. The first attempt produces a fundamental inconsistency in economic logic. The second brings together forms of efficiency to portray an efficiency nightmare.

In the Posner and Easterbrook Antitrust textbook, the introduction to their theory of monopoly states that "treating a dollar as worth the same amount to everyone or, in economics jargon, ignoring distributive considerations" 464 solves the problem of allocative efficiency's dependence on distribution. But their treatment of money is fundamentally inconsistent with their treatment of everything else. That is, their anomalous handling of money allows them to ignore wealth distribution effects in the midst of a wealth-maximization model. The inconsistency derives from excluding the important fact that money, like everything else, is subject to the basic psychological principle that underwrites traditional consumer welfare analysis - the principle of diminishing marginal utility that grounds the "Law of Demand." 465 In simple terms, the principle holds that the more of a good-ice cream, for example-people already have, the less each additional scoop will satisfy them, and the less they would be willing to pay. Posner and Easterbrook apply this principle to everything but money, which constitutes the model's medium of exchange and its measure of wealth. Thus, this vision of the "Law of Demand" suffers from a significant blind spot at its center. ${ }^{466}$ As a result of this exceptional treatment of money, the idea of wealth is disconnected from the idea of utility and thus from the service of consumer welfare. 467 In short, wealth maximization cannot be offered as a meaningful measure of preference. ${ }^{468}$

Ultimately, the casebook asserts that this strategy to depoliticize effciency would eliminate the normative economic significance of wealth

464. Id. at $9-10$.

465. See, e.g., P. SAmuelson, Economics 23-26, 59-61 (7th ed. 1967).

466. For an explication of a blind spot or gap at the very center of the LEA's price discrimination analysis, see infra notes 578-87 and accompanying text.

467. See Posner, The Ethical and Political Basis of the Efficiency Norm in Common Law Adjudication, 8 HOFSTRA L. REv. 487 (1980) (argument for wealth as an independent value).

468. Further, this desired separation from politics, from questions of distribution, cannot be maintained-whether the value served is utility or wealth. For just as tastes change with incomes, so wealth both affects and is affected by prices-that is, by the value of money. See Kelman, supra note 34 , at 275 \& n.4 (1983) (criticizing as overly simplistic the economic analysts' view that all behavior can be viewed at any discrete moment as utility-maximizing without considering capacity for one's tastes to change). This excluded notion of decreasing marginal utility can be a predicate for a utilitarian argument for equalization of income or wealth. See Posner, supra note 19, at 115 (assumption of decreasing marginal utility, in combination with other utilitarian assumptions, enables one to show that equal distribution of wealth will produce more happiness than any other distribution, unless costs of achieving such distribution equal or exceed benefits in greater happiness). 
redistribution from consumers to monopolists. ${ }^{469}$ While Posner and Easterbrook do discuss some implications of choosing wealth as their social value, they remain silent about the normative import and controversial nature of maximization as the standard for comparison. Wealth maximization neither implies nor is implied by either productive or Pareto efficiency. ${ }^{470}$ Thus, monopolistic income transfers have no normative economic significance only if economics no longer looks to productive or Pareto efficiency effects. And that condition is not met. Instead, many scholars and policymakers, including Posner, think in such efficiency terms.

In his two antitrust monographs, Posner criticizes traditional economic analysis of both the monopoly problem and price discrimination. His critiques purport to demonstrate that attendant "social costs" are higher than those recognized by traditional economic analysis. Thus, it would seem that Posner would call for intensified prosecution to curtail this waste of society's resources. He does not. ${ }^{471}$ Instead, two clear implications of his analysis indicate that free markets are preferable. First, these social costs are attributed to a particular kind of competitioncompetition for monopoly profits. Because this market activity can be described as competition, it must be good-efficient in some sense. Second and more important, Posner's critiques have a disarming purport. They portray these higher social costs as effectively defusing the "social concern" of monopoly profits. The higher costs reach the level of monopoly prices. In short, Posner means to convince us that there simply are no monopoly profits requiring social concern. ${ }^{472}$ But these same social costs deprive Posner's political economy of its appeal-the social cost savings attributed to the productive efficiency of large-scale firms.

Traditional economic concerns about monopoly take the form of conclusions about decreased output and higher price. A monopolized

469. PoSNER \& EASTERBROOK, supra note 223, at 9-10. The text also notes the welfare loss due to decreased output and to costs of monopolizing. Id. at 10-11 (citing Harberger, Monopoly and Resource Allocation, AM. EcoN. REv., May 1954, at 77 (undertaking to quantify welfare loss caused by monopolies)).

470. See, e.g., Kornhauser, supra note 298 , at 596. Nonetheless, Pareto optimality and wealth maximization standards are structural equivalents, and thus the major objections to the utility-based measure apply as well to the wealth-based measure. Id. at 592 .

471. Posner argues that free-marketeering is the most efficient second-best solution. See ANTITRUST LAW, supra note 6, at 14 ("The opportunity to obtain a monopoly profit . . . will attract real resources into the activity of becoming a . . monopolist [in the given field] . . ., thereby transforming the [monopoly profit] into a social cost that (1) can be eliminated by destroying the monopoly and (2) in all likelihood exceeds the losses . . . resulting from the fact that the monopolized products] are slightly more costly to produce than the substitute product.").

472. But cf. Scherer, supra note 438, at 978 (arguing that Posner's indictment of monopolies as inefficient and unprofitable depends on the unsupported assertion that monopoly profits are transformed into costs as entrepreneurs compete for monopoly positions). 
market produces less than a competitive one, penalizing consumers who would buy at the lower competitive price but who now purchase substitutes. Posner argues that monopolies produce another kind of inefficiency as well-because their profits are higher, such firms have an incentive to expend more in maintaining those higher profits. Moreover, rivals have an analogous incentive to spend more in competing for those profits, while consumers incur costs to avoid paying more. These costs of monopolization are inefficient because they waste society's resources. ${ }^{473}$ In other words, they are productively inefficient.

Furthermore, Posner argues that the traditional view that price discrimination increases output to that of a competitive market is wrong. $\mathrm{He}$ attributes the error to several oversights that underestimate costs. First, increasing costs and decreasing quality of market information result in imperfect price discrimination. The output effects of imperfect price discrimination are not determinable, ${ }^{474}$ as therefore are the efficiency effects. Some benefits of economies of scale may be lost. Lower production may also be inefficient in the sense that less wealth is produced. Second, buyers incur costs to avoid paying higher prices. Finally, Posner argues that, as in the case of monopolies, price discrimination generates competition for higher profits, thereby resulting in higher costs. ${ }^{475}$

Posner's world of monopoly without monopoly profit simply does not comport with our experience or our intuition. But even if believable, this neoclassical fantasy is an efficiency nightmare. A vision of powerful large-scale enterprise, wasteful in a perfectly economically rational manner, offers no redeeming virtue beyond its imaginative absurdity. What good are large firms if they are not productively efficient? ${ }^{476}$ Here, the higher social costs cancel out the benefit of large firms-economies of scale. How then do such firms benefit society? If we take instead Posner's goal of efficiency to mean wealth maximization, then the harm is exacerbated. In particular, the law of demand leads firms with market power to produce less in order to charge monopoly prices. If anything, the goal of wealth maximization encourages productive inefficiency. Indeed, only in a perfectly competitive society will wealth-maximizing

473. ANTITRUST LAW, supra note 6 , at 11-13.

474. See, e.g., id. at 64-65 (whether the imperfect price discrimination that one encounters in the real world leads to greater or smaller output than single-price monopoly is an empirical question); $\mathbf{R}$. BoRK, supra note 1 , at 398 .

475. The RPA, supra note 10, at 9-12. See ANTitrust LAW, supra note 6, at 62-65.

476. The question is posed in terms of productive efficiency because Posner's examples of monopolies' efficiencies tend to conclude in those terms. See, e.g., ANTITRUST LAW, supra note 6, at 10-18. 
states be productively efficient. ${ }^{477}$

Posner's marginal logic leads to an efficiency nightmare-a political economy that promotes large-scale enterprise while undermining productive efficiency. In sum, this LEA-this efficiency-based monopolization of price discrimination argument-does not fulfill its promise. Despite the indeterminacy of efficiency, despite the impossibility of either coherent theory or practice, and despite the controversial choice of wealth as the only measure of preference, the LEA persists in grounding its visions of competition, monopoly, and societal improvement in the conceptual morass of efficiency. The abysmal failure of this approach prompts a reconsideration of efficiency's focus-a speculation on two intertwined logics of marginality.

\section{Conclusion: Logic at the Margin}

Posner's work fits nicely with prior LEA monopolization of antitrust argument and with recent efficient capital market theory. ${ }^{478}$ Although his criticisms of traditional economic analysis initially look like a brief both for "the dismemberment of leading firms" 479 and for the prosecution of economic price discrimination, ${ }^{480}$ they turn out to be polemics against social concerns and the normative significance of distributive consequences. Despite a description of the higher social costs attributable to monopoly and price discrimination, and despite an assertion that the output of a price-discriminating monopolist will not exceed that of a single-price monopolist, Posner does not suggest amendment or more enlightened enforcement. Instead, he calls for statutory repeal.

But as we have already seen, that would only be a formality. Whether or not the Robinson-Patman Act ever occupied the center stage of antitrust law, it certainly does not any longer. ${ }^{481}$ As the dynamic between Posner's two antitrust monographs captures in miniature, we envision the statute as a specter at the edge of proper antitrust argument. Emptied of its sociopolitical content and deprived of a claim to logic, it has become our symbol of irrationality, relegated to the margin of a doctrinal domain dominated by the rule of reason and disciplined by an economics of efficiency. ${ }^{482}$ As Yale Brozen concludes in his preface to The

477. See Kornhauser, supra note 298, at 597.

478. For an introduction to efficient capital market theory, see generally R. PosNEk \& K. SCoTt, supra note 388 .

479. ANTITRUST LAw, supra note 6, at 5 .

480. See ThE RPA, supra note 10, at 10-12 (discussing the deadweight social costs of perfect price discrimination).

481. See supra note 10 and accompanying text.

482. Cf. M. Foucault, MAdNESS AND Civilization, supra note 4, at-38-64 (discusses the Age of Reason's "Great Confinement" of madness to the margins of proper society). 
$R P A$, "Professor Posner finds-I believe correctly - that 'the repeal of the Robinson-Patman Act would not leave any gap in the control of genuinely anticompetitive practices." "483 To the contrary, Brozen and Posner agree that it is precisely the Act's enforcement that constitutes a gap in proper antitrust policymaking. Only repeal can bridge that fault. They agree with Bork that the fault is an irrationality that infects an otherwise scientific domain whose core is the logic of efficiency and whose borders must be guarded against disqualified argument. All sorts of disqualified knowledge constitute that gap-not only local commercial interests in fair competition symbolized by Utah Pie's interpretation of the Act, ${ }^{484}$ but also other peripheral concerns: equitable distributive consequences, Jeffersonian entrepreneurialism, and a common law methodology. ${ }^{485}$

Imagine that the LEA call for repeal is heard and that Congress recalls its defective price discrimination statute. Brozen and Posner's gap is gone. What remains? Genuinely economic argument monopolizes price discrimination doctrine. Purely efficiency-based analysis can produce rationalized antitrust policy. However, a glance at the "core" of this system reminds us that Posner's efficiency logic in practice is indeterminable and incoherent. Even more problematic, the discipline of economics defines allocative efficiency as a function of distributive consequences. That is, the discipline's center is itself dependent upon repealed social concerns, on excluded ideas. The logic of efficiency depends upon propositions that the LEA has defined out of the discipline. As a result, the system's center is itself outside the system. Efficiency is itself excluded, leaving nothing to occupy the original position at the center of a genuinely economic analysis of antitrust law. We are confronted with a gap at the system's very core.

Whatever the substance of efficiency, we have seen its effects in the power to discipline antitrust doctrine, to maintain discursive borders that exclude disqualified argument. But is efficiency itself just a symbol, a placeholder? ${ }^{486}$ Perhaps its association with free competition serves the ideological demands of personal autonomy in a society distrustful of too much government. But if personal autonomy in the form of free exchange empowers efficiency, then an equalization of initial positions-a redistribution of economic power-would enhance the opportunities for

483. Brozen, Foreword to THE RPA, supra note 10.

484. Utah Pie Co. v. Continental Baking Co., 386 U.S. 685, 702-03 (1967) (holding that sporadic price-cutting by defendants designed to erode competition from local frozen pie company violated section 2(a) of Robinson-Patman Act).

485. Bork, supra note 162 , at 12.

486. Zero-which has only symbolic value-functions as a placeholder. 
such free association and exchange. The Act's mission of equalization would not appear mad. Perhaps efficiency represents materialistic demands-producing more from less. But tensions between the ideas of wealth maximization and productive efficiency fracture that theory. Perhaps efficiency serves desires for stability. A demand for security calls for maintaining a status quo. Current interests always seek protection from change, an entitlement to economic power, a property interest to estop governmental redistribution. The idea of free competition under the banner of efficiency disciplines such exercise of political power. In these ways and others, efficiency can be observed working at the borders of antitrust argument-guarding them against marginal concerns.

Yet each of the foregoing concerns that seems to animate efficiency is itself marginal. If none of those marginal concerns occupies the vacant center-the place held by efficiency-what fills the gap demonstrated in the logic of efficieny? Every response to these questions calls for the same movement. Every search for a center turns out to be a perplexing return to the margin. Indeed, the Law and Economics Approach itself demands that return. Despite a claim of centrality, the LEA's concept of efficiency is founded in its own logic of marginality: ${ }^{487}$ Productive efficiency is concerned with marginal cost; allocative efficiency serves marginal utility; and monopoly profits are calculated according to the intersection of marginal revenue and marginal cost. In short, the LEA's focus on the margin is central to its own logic and value sytem. Its logic teaches that true value-wealth-is observed only at the margin. At the same time, it identifies this marginal truth as its very center.

What if we apply a logic of marginality and centrality to the LEA's price discrimination argument and demand that its marginal truth be drawn inward? What would confront the monopolizing power symbolized yet unaccompanied by its excluded core-efficiency? Drawn inward from the margin would be all those social and political objections symbolized by the Robinson-Patman Act, all those displaced logics, those mad sources of antitrust argument disciplined by the LEA. If the Robinson-Patman Act and its complement argument convene at the center of proper antitrust argument, what form of madness do we risk? If we embrace the specter of anti-antitrust, what sort of counterdisciplinary scheme must we trust?

487. Although the LEA's economic notion of marginality is not formally defined in terms of core/periphery or center/margin, the connections are more than fortuitous. Simply put, the eco. nomic idea focuses on the borders between, for example, production and nonproduction, or consumption and abstinence. Just as the margins of a printed page constifute the proper border for the centered text, so does the economic idea of marginality circumscribe the proper subject for disciplined analysis of microeconomically significant events. In sum, the economic idea of marginality is interested in boundary conditions. 
Despite the LEA's determination to rid antitrust analysis of the in- coherent price discrimination doctrine and irrational antitrust argument associated with "populist" concerns, we would have no choice but to trust in the sociopolitical complexity of traditional legal analysis. At the same time, because LEA orthodoxy displays its own brand of incoherence and illogic, LEA-inspired doctrine at first appears different but no better. It might be worse. Rather than an explicit dialogue among five traditional sociopolitical voices speaking in favor of economic efficiencies, Jeffersonian entrepreneurialism, fair competition, equitable distribution, and common law method, we have antitrust doctrine bound to an approach that obfuscates its sociopolitics. But for those who see the LEA as the rule of reason, the fear is that once attention turns to marginal transactions, once sociopolitics again becomes a powerful imaginative force, then the possibility of doctrinal stability is lost. Then, antitrust argument could empower undisciplined, perhaps disruptive political and economic voices; it might free logics and social values imprisoned in what was once thought of as radical legislation. Pragmatic dialogues of social value choice might interrupt and disrupt the Law and Economics Approach's monologue of social scientism. We might then be called upon to make complex and difficult judgments rather than fantastical measurements. 